\title{
La evolución urbana de Alcalá de Henares entre los siglos XIII-XVII: la secuencia estra- tigráfica del colegio-convento de "Mínimos de Santa Ana” (Alcalá de Henares, Madrid)
}

\author{
The evolution of an urban space between XIII-XVII centuries: the strati- \\ graphic sequence of "Minimos de Santa Ana's" convent-college (Alcalá de \\ Henares, Madrid)
}

Manuel Castro Priego*, Lauro Olmo Enciso*, Mª Mar Gallego García

\begin{abstract}
RESUMEN
La evolución del poblamiento medieval en el valle del Henares entre los siglos XII-XV, ha carecido hasta la fecha de análisis arqueológicos. Alcalá de Henares (Madrid), y su desarrollo urbano medieval es un claro ejemplo. La excavación del sector septentrional del convento de Mínimos de Santa Ana ha aportado indicadores claros sobre el comienzo de la ocupación en el sector suroccidental de la ciudad, desde finales del siglo XIII. Éstos señalan un crecimiento de la villa con parámetros diferentes a los descritos en las fuentes documentales. Los datos recuperados a través de la cultura material cerámica permiten ampliar el panorama de las producciones locales y la llegada de series levantinas a lo largo de la Baja Edad Media.
\end{abstract}

Palabras Clave: contextos materiales medievales, loza, complejo conventual, moneda, evolución urbana, Alcalá de Henares, Arqueología Medieval.

\section{INTRODUCCIÓN. LOS ORÍGENES DE LA ALCALÁ MEDIEVAL}

Gran parte de los análisis históricos que han centrado su interés sobre el surgimiento de la villa de Alcalá de Henares (Madrid) (Figura I), a lo largo de la Plena Edad Media, han señalado un modelo de crecimiento urbanístico unilineal. Este último se inicia tras la definitiva conquista y adscripción al Arzobispado de Toledo del

\begin{abstract}
The fieldwork of the Santa Ana College northern sector, has provided indicators of the beginning of the medieval settlement in the southwest area of Alcala de Henares (Madrid). The digging works has registered an initial occupational phase at the end of the thirteenth century, and paulatine urban densification in the second half of the fifteenth century. The data retrieved through the ceramic material culture, shows the activities of local pottery production and the arrival of the Maiolica contexts.
\end{abstract}

Keywords: medieval material contexts, Maiolica, conventual complex, coin, urban evolution, Alcalá de Henares History, Medieval Archaeology.

extremo occidental del Valle del Henares, a finales de la segunda década del siglo XII. La caída de la taifa de Toledo en 1085, abrió un largo paréntesis de tres décadas en las que lentamente la corona de Castilla pudo comenzar a asumir el control definitivo del antiguo reino de los Banū Dĩ Nūn. Para ello, desarrolló una activa política territorial con la connivencia de las autoridades eclesiásticas, deseosas de recuperar los antiguos arzobispados altomedievales.

* Universidad de Alcalá. Área de Arqueología: lauro.olmo@uah.es; manuel.castro@uah.es. Este estudio ha sido realizado dentro del Proyecto del Plan Nacional de I+D+I HAR 2009- I 627 Construcción y dinámicas de un paisaje medieval, financiado por el MINECO 
Éste fue el caso de la región en torno a Complutum (Alcalá de Henares, Madrid) que, tras su definitiva conquista a comienzos del siglo XII ( 1 । 18 ) será donada al arzobispado toledano en I 129 (XIMÉNEZZ DE RADA, 1987: I29; FITA COLOMÉ, 1885:339-341). El grueso de las fuentes textuales subrayan, sin embargo, que en el momento de la ocupación cristiana el núcleo poblacional se concentraba en la antigua fortaleza de origen islámico, situada en la margen izquierda del Henares "... de castro, quod nunc dicitur Alcala, antiquitus vero Complutum, cum omnibus suis terminis antiquis quos habuit quomodo melius extitit..." (FITA COLOMÉ, 1885: 339).

El castro de Qal'at'Abd al-Salām -la original denominación islámica con la que se conoce el castillo, fundado en el s. IX (Figura 2) - contaba con un extenso alfoz. B. Pavón Maldonado sostiene (PAVÓN MALDONADO, 1982: 37) que con anterioridad a la conquista cristiana, su territorio limitaba con el de Ribas al oeste, por encima de Santorcaz al norte, e incluía las aldeas de Ajalvir, Camarma de Esteruelas y Daganzo, así como Alcolea de Torote (Guadalajara). Investigaciones más recientes (CASTILLO GÓMEZ, 1989: | |8-133), describen un territorio con unos límites diferentes, con una menor expansión al norte y al este de la planteada por Pavón y una dimensión más reducida. Pero, al margen de las características del territorio en el siglo XI-XII, el alfoz alcalaíno se incrementó notablemente en el siglo XV (Figura 3). Es entonces cuando controla administrativamente los valles del Henares hacia el oeste, y el Tajuña en su curso medio, desde el límite actual entre las provincias de Madrid y Guadalajara, en el municipio de Ambite, hasta Perales de Tajuña (CASTILLO GÓMEZ, 1989: |18-133).

El abandono ocupacional de la mayor parte de las fortalezas islámicas de segundo orden en torno al Henares y Jarama, como era el caso de
Cervera, Ribas y Qal'at'Abd al-Salām, se inicia en el siglo XIII (GONZÁLEZ, 1975: 178; MARTíNVISO, 2000: 199). A mediados de esa centuria empieza a acuñarse el término de Alcalá la Vieja para identificar a Qal'at'Abd al-Salām (TORRES BALBÁS 1959: 167-168). Sin embargo, el deseo de seguir manteniéndola como manifestación espacial de la autoridad señorial, explica su particular situación jurídica, ventajosa frente al incipiente núcleo del Burgo de Santiuste (futura Alcalá de Henares) hasta, al menos, 1253.

En torno a 1250, por tanto, la ocupación del antiguo territorio complutense se articulaba en torno a dos núcleos próximos (Figura 2). El de formación más reciente correspondía con un pequeño asentamiento en las proximidades de la antigua Vía Emerita-Caesaraugusta, en cuyas inmediaciones se comenzó la construcción de un primitivo templo, en honor de los mártires locales Justo y Pastor. De este último tenemos ya noticias a mediados del siglo XII, dentro de la descripción de los diezmos reales concedidos por la Corona al arzobispo toledano Bernardo ( I086-I I24) y mantenidos bajo el gobierno de su sucesor, Raimundo (1 124-1|52), en Il 48 d. C I:

Además del modelo territorial señorial, con la fortaleza como centro neurálgico, el arzobispado impondrá una nueva organización fiscal, con la delimitación de parroquias como eje vertebrador. La incipiente villa en la margen derecha del río Henares, ofrecía unas condiciones de comunicación en las que se aunaba la conexión suprarregional entre el occidente y oriente del centro de la Península, junto a la unión con los antiguos corredores que permitían un rápido tránsito hacia la Mancha, a través de los limitados puntos donde era posible el cruce del Tajo.

La redacción de un primer gran fuero a mediados del siglos XIII bajo el mandato del

\footnotetext{
I FITA COLOMÉ, F. "Santuario de Atocha. Bulas inéditas del siglo XII", B.R.A.H.,VII, Madrid, I885: 217. Fita localiza esta referencia en una Bula de Eugenio III, depositada actualmente en el Archivo Histórico Nacional y fechada el I 6 de abril de I| 48 d. C. El otorgamiento de los diezmos fue ratificado con posterioridad, en otros documentos papales que reproducen en los mismos términos el texto señalado, Bula de Alejandro III en | |6 | d. C., Urbano III | 87 d. C. y Celestino III en | 92 d. C. La mención a su concesión alcanza también las primeras décadas del siglo XIII d. C., como se cita en la Bula de Inocencio III en marzo de I2 I0, en la que se vuelve a considerar dos entidades diferentes, por un lado el "castrum Alcala", y por otro la "ecclessia sanctorum lusti et Pastoris". Torres Balbás sigue también a Fita en su estudio de la evolución del núcleo cristiano, TORRES BALBÁS, L.: "Complutum, Qal'at 'Abd al-Salām y Alcalá de Henares", Boletín de la Real Academia de la Historia, CXLIV, Madrid, I 959: I74- I77.
} 
arzobispo Jiménez de Rada (1209-1247), subrayan la definitiva consolidación de la nueva villa. Algunos investigadores sitúan su elaboración en torno a 1240 (TORRENS ÁLVAREZ, 2002), después de la definitiva finalización de las incursiones almohades en el valle del Tajo y Henares, especialmente activas entre 1196 y 1205. Su implantación no significará el abandono del antiguo castro, que mantendrá un régimen foral especial y será sometido a numerosas reconstrucciones y rehabilitaciones, reflejo del poder señorial lo largo de los siglos XIV y XV 2 , aunque con un lento despoblamiento de sus inmediaciones.

La concesión a la villa del régimen foral de Alcalá la Vieja, en 1253, demuestra ya la definitiva intención de acrecentar el nuevo núcleo, ratificado en 1304, por el arzobispo Gonzalo Diez Palomeque ( I 299- I 3 I0) (TORRENS ALVÁREZ, 2002). Junto a la mención del templo de San Justo y Pastor fundado a mediados del siglo XII, se añade la de de la iglesia de Santa María la Mayor (Figura 4), levantada a mediados del siglo XIII d. C. (PORTILLA y ESQUIVEL I725: 278). Todo ello indica un crecimiento urbano rápido, y por otra parte, inicialmente disperso, ya que la situación de esta última estaba alejada tanto del palacio arzobispal como de San Justo. Sólo así se explica que la paulatina vertebración o densificación urbana en torno a Santa María la Mayor, fuese mínima hasta la segunda mitad del siglo XV. También está documentada la existencia de la ermita de de San Juan de los Caballeros, situada en la actual plaza de Cervantes, de la que tenemos noticias desde 1268 y donde, en el siglo $X V$, trasladó el arzobispo Carrillo la parroquia de Santa María (PORTILLA y ESQUIVEL 1725: 278-279). Es llamativo el intento inicial de organizar un sistema de parroquias, que sin embargo se limitaba a un reducido número-dos-hasta los albores del siglo XVI. L. Torres Balbás atribuye, sin embargo, la limitada existencia de colaciones a la particular situación jurídica de la villa en el Arzobispado de Toledo, frente a otras ciudades no dependientes (TORRES BALBÁS, 1959: 181- 182).
Alcalá no contó con sinagogas o mezquitas de grandes dimensiones. La transformación de la Mezquita Mayor en la nueva parroquia de Santiago en |50|, sita en la calle del mismo nombre, levantada sobre la construcción islámica, indica un complejo de pequeñas dimensiones, incapaz de albergar a un grupo importante. La población judía debió tener un mayor peso demográfico y se concentraba en torno a la Calle Mayor, conservándose todavía a finales del siglo XIX los restos de la que era la Sinagoga Mayor, situada en el $n^{\circ} \mathrm{IO}$ de la Cl Carmen Calzado (CASTILLO GÓMEZ, 1989: 78).

\section{LA APORTACIÓN DE LA ARQUEOLOGÍA}

El análisis de la evolución y origen del núcleo medieval y de las características urbanas y materiales de éste, ha carecido hasta la fecha de estudios arqueológicos sistemáticos, en gran medida como resultado de varios procesos coincidentes. Por un lado, la falta de un desarrollo y aplicación efectiva de la normativa de protección, -que ha hecho que el grueso de las intervenciones arqueológicas se realicen dentro de acciones de urgencia y salvamento, en muchos casos con criterios no suficientemente explicitados-. En segundo lugar, la subsidiariedad del análisis arqueológico frente los estudios e interpretaciones textuales, que subrayan el crecimiento de la villa en varias fases, marcadas ambas por la construcción de dos cercas diferentes, que se han convertido en el elemento recurrente en el estudio de la villa medieval. Su posible existencia, y la ampliación de la muralla a lo largo del primer tercio del siglo $\mathrm{XV}$, merecen un estudio riguroso. La investigación arqueológica empieza a señalar la construcción de un recinto cercado exclusivamente en torno al conjunto arzobispal durante los siglos XIII-XIV. La definición definitiva de la cerca que envuelve la villa, sin embargo, no se produciría de manera inequívoca hasta inicios del siglo XV (CASTRO PRIEGO, 20II).

2 Tal como están poniendo de manifiesto las intervenciones arqueológicas que se desarrollan en él dirigidas por M. Presas, E. Serrano y M. Torra. 
La primera de la murallas, levantada en el siglo XIII, tendría forma circular e incluía un extenso espacio intramuros de 37 ha., con un trazado dispar según los diversos estudios históricos (GARCÍA FERNÁNDEZ, 1952; CERVERA VERA, 1987; ROMÁN PASTOR, 2003), especialmente en su ángulo suroccidental. A pesar de la asunción en los distintos trabajos arqueológicos de su existencia, no ha sido detectada su traza, excepto en el recinto amurallado que protege el palacio arzobispal (GARCÍA LLEDÓ, 2003). Aunque en este último caso no se ha realizado todavía una sistematización que explique las diversas fases constructivas. Actualmente, por tanto, no sólo desconocemos su trazado, salvo la interpretación hipotética a partir del parcelario actual y decimonónico, sino también sus características constructivas y evolutivas (Figura 5).

Pocas dudas existen en cambio, sobre el momento de edificación de la segunda cerca, que podemos situar en torno al año |42| (ROMÁN PASTOR, 2004; CASTRO, 201 I: 29-39), a través del largo pleito que dirimió la villa con su territorio, con motivo de su construcción, promovida y solicitada por los arzobispos a comienzos del convulso siglo XV. Su trazado delimita, en gran medida, todavía gran parte del Centro Histórico de Alcalá de Henares (Figura 6). De ella se han encontrado restos en la Av. Vía Complutense/Pza. Atilano Casado, C/Ronda de Pescadería 22 y Colegio de Santo Tomás (C/Colegios). Las características de la muralla corresponden con la imagen que podemos observar en el conocido grabado de Anton Van den Wyngaerde que representa la villa hacia 1565 (Figura 7: A). En él se observa una estructura de torres rectangulares, zócalo de mampostería y alzado de tapial, aunque ya a mediados del siglo XVI con claros signos de abandono.

\section{I. El espacio del primitivo recinto}

El grueso de las intervenciones arqueológicas efectuadas en el espacio del hipotético primer recinto (s. XIII), han aportado una estratigrafía recurrente, señalando algunos elementos que permiten plantear algunos interrogantes en el modelo de crecimiento urbano anterior a prin- cipios del siglo XIV. Los datos contrastan con las informaciones obtenidas en las actuaciones arqueológicas de Madrid y Guadalajara (PRESAS et alii, 2009), con las que existen importantes diferencias. En estos últimos núcleos, no se produjo un traslado topográfico del centro original de fundación islámica a un nuevo espacio, como hemos mencionado que ocurrió en el caso de Alcalá de Henares.

El área próxima a la Iglesia Magistral -Pz. de los Santos Niños, C/Tercia, Victoria-Seises y Damas- es la que muestra una mayor pluriestratificación, tal como han puesto de manifiesto las diversas intervenciones arqueológicas, con la documentación de una ocupación altomedieval previa. Ejemplo de ello es la excavación de una necrópolis fechada genéricamente entre los siglos VII-VIII, I en la CNictoria, C/ Tercia (MÉNDEZ y RASCÓN 1989; ROMÁN GARRIDO,1993) (Figura 8). En algunas zonas próximas, -Cl Seises y la Lonja de la Magistral (Figura 9)-, así como en el convento de Mínimos de Santa Ana, se detectan también indicios que señalan la ocupación de esta zona a lo largo de los siglos III-VII d. C., aunque todavía sin una definición precisa de sus características. Pertenecientes a esta fase son también, las fosas-basureros localizadas en la C/Damas (POLO LÓPEZ y DÍAZ DEL RíO 1992; POLO LÓPEZ, 1999), o la documentación de estructuras murarías muy arrasadas en la C/ Seises 2 (DÍAZ DEL RíO y ROMÁN GARRIDO, 1996) y fechadas entre los siglos IV-V d. C.

En el entorno inmediato de la actual Iglesia Magistral también se han documentado restos de un pavimento de opus signinum, que los investigadores han fechado genéricamente en época altoimperial (GARCÍA LLEDÓ y MENDUIÑA GARCÍA, 2008). En el interior del edificio se ha comprobado la existencia de una estructura muraría de cantos rodados, que se ha considerado perteneciente a la primitiva iglesia de San Justo y Pastor, levantada a finales del siglo V-inicios del siglo VI (SÁNCHEZ-MONTES y OLMO ENCISO, 1999:395-396) (Figura 9).

No existen, sin embargo, indicios de continuidad habitacional posteriores al siglo VIII (CASTRO, 201 1:213) hasta la aparición inequívoca de un nuevo hábitat a partir de finales del XII 
inicios del siglo XIII. Este aspecto confirma, inicialmente, el abandono del llano y el traslado de la población a la otra margen del río Henares en época altomedieval, dentro del proceso de formación de un nuevo paisaje en torno a la fortaleza de Qal'at'Abd al-Salām.

Este largo periodo de discontinuidad ocupacional, tiene su reflejo material y estratigráfico en la existencia de extensos depósitos de naturaleza areno-arcillosa sin material arqueológico asociado, que cubre las fases altomedievales en la C/Victoria y Seises, pero también algo más al sur, en la C/ Damas, 4 (TURINA, 1986a) y Convento de Mínimos de Santa Ana. Sobre la naturaleza de éstos, el grueso de las actuaciones han coincidido en considerarlos resultado de la acción sedimentaria fluvial del Henares, aunque queda por resolver una posible modificación antrópica de estos depósitos a lo largo de la plena Edad Media.

La posterior ocupación pleno y bajo medieval de este sector de la ciudad, que se inicia con la construcción de un nuevo templo de San Justo y Pastor en el siglo XII, se caracteriza - para el siglo XIII e inicios del XIV- por la existencia de una importante presencia de silos-basureros sin estructuras habitacionales asociadas. Ejemplo de ello, sería de nuevo la CNictoria n 2 (ROMÁN GARRIDO, 1993: 49-57), pero también el Antiguo Convento de Mínimos de Santa Ana. La localización de diversas estructuras murarías en el interior de la actual Iglesia-Magistral de San Justo y Pastor, cuya fisonomía actual fue levantada a finales del siglo $X V$, confirman la existencia de al menos una construcción bajo y plenomedieval anterior, con un extenso espacio cementerial en su entorno inmediato (Sánchez-Montes y Olmo Enciso, 1999). En el lado occidental, a los pies de templo, durante la reciente rehabilitación de la lonja, se ha documentado una necrópolis con varias fases superpuestas sin discontinuidad, que parece finalizar en un momento indeterminado del siglo XVII, pero que se inicia en el siglo XIII (GARCíA LLEDÓ y MENDUIIÑA GARCÍA, 2008: 165-166).

En el sector central de la villa destacan diversas intervenciones en la calle Santiago, que permitieron la elaboración de una primera tipología cerámica elaborada por A. Turina. A mediados de la década de los 80 , se produjo la excavación parcial del solar de la C/Santiago $n^{\circ}$ I5, en la que se identificó un primer conjunto cerámico sin adscripción estratigráfica clara, que fue datado entre el siglo XIV y XV asociado a dos piezas numismáticas -vellones-, una del último tercio del siglo XIII-inicios del XIV (acuñado bajo el gobierno de Jaime || |276- |3| |) y otra del XV (Enrique IV I 454- I 474) (TURINA, 1985 y 200 I) (Figura 10). Los tipos más representativos eran las formas abiertas en loza, que se caracterizaban por la representación de hojas de palma, junto a series en verde-manganeso de organización temática y decorativa, con estrecha relación con tipos turolenses y especialmente levantinos (PASCUAL y MARTÍ, 1985), aunque con una mayor simplicidad organizativa (TURINA 200 I: 802-803).

Algo más al este, en el $n^{\circ} 22$ de la misma calle, se ha documentado una reducida secuencia bajomedieval en el solar ocupado por el convento de Santa María la Egipciaca, levantado en el siglo XVII. El edificio religioso unificó varios solares de la trama urbana bajomedieval, en la trasera de la C/ Mayor, aunando diversas viviendas y corralas situadas tradicionalmente en una de las áreas de la judería alcalaína. La excavación, muy reducida, ha permitido la constatación de depósitos de la segunda mitad del siglo XIV e inicios del XV (ARIAS CABEZUDO, 2005) (Figura I I).

Los datos obtenidos en intervenciones próximas como C/Cervantes, 8 (ALDECOA, 2008) o C/Ramón y Cajal, 8 (ROMÁN GARRIDO, 1990) (Figura 12) también señalan una utilización previa del espacio durante un momento indeterminado de los siglos XIII y XIV, que en todos los casos se caracteriza por la presencia de fosas-basureros, sin estructuras murarias asociadas. Similar situación se observa en las proximidades de la Pz. de Cervantes (C/Escuelas). En la mayor parte de las actuaciones -que permanecen inéditas y descritas sucintamente-, las dos fases que reiteradamente se documentan grosso modo-una primitiva ocupación de finales del s. XIII e inicios del XIV y la aparición de estructuras murarías a partir del s. XV-, se 
ven acompañadas de una aparente distinción tipológica y cronológica en el material cerámico. De los dos conjuntos, en el más temprano están ausentes las formas vidriadas, y predominan las piezas con pintura en ocre o rojo en su exterior, frente a otro inmediatamente posterior, en el que se subraya la presencia de loza y lotes integrados por piezas en verde manganeso (C) Escuelas, 5 (MALALANA, 1994).

De todo ello, se deduce la posible existencia de una primitiva fase de ocupación del espacio del primitivo recinto, caracterizada por la presencia frecuente de fosas-silos, utilizadas posteriormente como basurales, con ausencia de formas vidriadas, que las distintas intervenciones han fechado cronológicamente entre los siglos XI-XIII ${ }^{3}$. Posteriormente, esta fase sería desmantelada -ó cubierta según los casos-, por la definitiva consolidación de un primitivo parcelario difícilmente fechable con anterioridad a mediados del siglo XIV. Este último fue alterado ya en el siglo XVI (C) Escuelas, 5 (MALALANA, 1994); C/Tercia (ARIAS CABEZUDO, 2006a); y Seises (ARIAS CABEZUDO, 2006b), coincidiendo con las intensas reformas urbanas que afectaron a la trama medieval tras la consolidación del proyecto universitario, y el surgimiento de la villa barroca.

\subsection{EI Área del Palacio Arzobispal}

Las diversas intervenciones arqueológicas que se han efectuado en el recinto del Palacio Arzobispal, se han centrado principalmente en dos aspectos: por un lado, la identificación cronológica de los orígenes del edificio, y por otro, la seriación de los diversos trazados de la cerca. Salvo actuaciones recientes, el grueso de los trabajos se han caracterizado por el reducido tamaño de las áreas de estudio y la subsidiariedad de la arqueología en extensos proyectos de restauración y difusión. Sólo en ese contexto se puede entender lo limitado de lo aportado, que, a fin de cuentas, se ajusta a la evolución cronológica-tipológica del edificio planteada a lo largo de la segunda mitad del siglo XX, y sintetizada por B. Pavón (PAVÓN, 1997).

El primitivo conjunto-defiende este último investigador - estaría formado por un recinto cercado, cuyo trazado coincide genéricamente con el actual, y un palacio de planta rectangular en el extremo sureste, adosado a la muralla (s. XIII) (PAVÓN 1997: 125-127). A finales del siglo XIV el complejo sufriría una intensa reforma ordenada por el Arzobispo Pedro Tenorio († I 399), que significó el levantamiento de una nueva cerca, así como una ampliación significativa de la residencia palatina hacia el este, duplicándose su superficie y alterando la traza del recinto amurallado en su sector meridional. Posteriormente se produciría la apertura de un gran Patio de Armas, y la definitiva articulación del Salón de Concilios bajo el gobierno del Prelado Contreras ( | 423-1434), ya en el primer tercio del siglo XV (PAVÓN 1997: 129-137).

Los resultados de las actuaciones arqueológicas en el conjunto palacial han sido muy limitados. La excavación del entorno del Torreón del Ochavo -en el extremo suroriental- en 1992, pudo documentar la existencia de diversos elementos constructivos previos a la intensa reforma del complejo, en el siglo XV. Los resultados - publicados parcialmente (SÁNCHEZ MONTES, 1996: 250-252) (Figura I3: C)-, señalan la existencia de una primitiva construcción con zócalo de ladrillo y argamasa, con alzado, tal vez en tapial (s. XIII), frente a una posterior fase ya de finales del siglo XIV, que supone el inicio de la petrificación del edificio. La aparición de fábricas en tierra, en la muralla ya fue descrita durante la excavación de la Puerta de Burgos-al norte del recinto- por A. Turina entre 1986-1988 (TURINA, 1986b) (Figura I3 B), que confirmó la existencia al menos de dos recintos, y una intensa reforma de la torre-puerta, posiblemente en el primer tercio del siglo XV.

La campaña arqueológica del año $2007^{4}$ (Figura 13: B), que se centró en el sector

\footnotetext{
3 La posible ocupación anterior, no ha sido detectada a lo largo del Centro Histórico, salvo la mención de la documentación de varios silos-basureros fechados entre los siglos IX-XI en la calle Seises, 3 (García Lledó, 2003: 15).

4 Dirigida por A. L. Sánchez Montes y M.M. Presas Vías.
} 
occidental y septentrional de la muralla, ha reiterado que el primitivo recinto plenomedieval, construido en la segunda mitad del siglo XIII, estaba constituido por una fábrica de tapial, con dos soluciones distintas de cimentación: por un lado, una zanja o fosa, y por otra un zócalo de mampuesto sobre el que se apoyaba la edificación. El recinto en el sector meridional, en cambio, muestra una técnica constructiva en la que alternan en las partes inferiores de la muralla, mampostería entre hiladas de ladrillo asociada a fosa de cimentación, con paralelos con los datos obtenidos en el Palacio Arzobispal en 1992 (SÁNCHEZ-MONTES, 1996).

También se ha comprobado en este área (Campaña 20l0) que la construcción de las torres que actualmente se observan en este sector, y fechadas a finales del siglo XIV no significaron el desmantelamiento de todo el recinto, sino que se aprovecharon algunos de los elementos existentes hasta entonces. Además se han documentado varias construcciones adosadas o inmediatas al recinto amurallado en su lado sur, fechables originalmente en la segunda mitad del siglo XIV, junto a otro edificio ligeramente anterior, que en la actualidad se encuentra en proceso de excavación. Se consideran de la segunda mitad del siglo XIII e inicios del XIV un numeroso conjunto de fosas-basureros que han aparecido a lo largo del albacar. A pesar de la localización de diversos niveles de frecuentación que pueden ser, tal vez, relacionables con una ocupación de la segunda mitad del siglo XIII, parece quedar descartada una fase de hábitat anterior a esa fecha,-la posible existencia de una ocupación islámica ${ }^{5}$, o incluso altomedieval, por la cercanía a Complutum-. A pesar de la parquedad de los resultados y la escasa contrastación de lo descrito por las fuentes escritas, que señalan la definitiva articulación del conjunto en el siglo $X V$, existen algunos puntos en común con los otros sectores urbanos anteriormente mencionados, que se concretan en la expansión del conjunto palacial en un momento avanzado del siglo XIV e inicios del XV.

\subsection{El Sector Oriental}

En el sector oriental de la ciudad, se constata una cierta actividad urbana en la segunda mitad del siglo $X V$, muy unida a la consolidación del Camino de Guadalajara-actual C/ de los Libreros- y la ampliación de la cerca en la primera mitad de la centuria (ROMÁN GARRIDO y DÍAZ DEL RÍO, 1996; BENITO LÓPEZ, et alii., 200I) (Figura 14). La definitiva articulación parcelaria, sin embargo, se producirá ya en las dos primeras décadas del siglo $X \mathrm{Vl}$, y unida al proyecto constructivo emprendido por el Cardenal Cisneros desde 1495, con el fin de asegurar la instalación del complejo universitario. Para ello, se aprovechó el área intramuros con una menor densidad demográfica, que había sido recientemente alterada en su sector central con la construcción del Convento de Santa María de Jesús, ordenada por el Arzobispo Carrillo de Acuña (| 446- | 482) en I 453. Este nuevo edificio religioso incluyó la iglesia de Santa María cuyo origen se sitúa a mediados del siglo XIII, sin que haya podido ser corroborada definitivamente su existencia durante las recientes excavaciones (SERRANO et alii, 2009 6). Se ha observado también que la instalación del convento coincidió con la expansión de una necrópolis en su extremo occidental. Los hallazgos numismáticos asociados a los enterramientos sugieren que la fase cementerial de ésta se situaría ya en la segunda mitad del siglo $X V$, y por tanto contemporánea de la construcción del nuevo edificio.

\section{LA DEFINICIÓN DE LA CULTURA PLENOMEDIEVAL EN EL VALLE DEL HENARES}

Las dificultades para afrontar una síntesis pormenorizada de la evolución urbana de la villa, se ha visto acompañada de un amplio des-

\footnotetext{
5 Una breve referencia a algunas de estas intervenciones figuran en la introducción de la reciente Memoria sobre la intervención arqueológica en el Cuartel de San Diego: SERRANO HERRERO, E., TORRA PÉREZ, M. PRESAS VÍAS, M.M. y SÁNCHEZ GONZÁLEZ, A. (2009), Memoria final de la intervención arqueológica realizada en la superficie afectada por el proyecto de construcción de la Biblioteca Central de Humanidades de la Universidad de Alcalá. Convento de San Diego, inédita, 2009: 13.

6 La intervención fue dirigida por L. Olmo, E. Serrano y M. Torra.
} 
conocimiento de la cultura material de los siglos XIII-XV d.C. No es un problema nuevo. Salvo los estudios planteados a lo largo de la década de los 80 para el caso de Madrid (RETUERCE, 2004), existe todavía un número reducido de secuencias estratigráficas publicadas de época bajomedieval en el centro de la Meseta. El vacío en los resultados es especialmente llamativo también en la documentación de depósitos de los siglos X-XI (SERRANO et alii., 2004).

La reciente publicación de una primera sistematización de las características y evolución de los materiales cerámicos entre los siglos IX-XV en el centro peninsular (Guadalajara, Madrid, Toledo), ha ofrecido un panorama amplio de las transformaciones técnicas y especialmente tipológicas de la cultura material cerámica (PRESAS et alii., 2009). La ausencia de estratigrafías fiables para el caso de Alcalá ha impedido completar esta primera visión sobre el valle del Henares, en la que existen algunas novedades.

Siguiendo los resultados que se han alcanzado especialmente para el caso de Guadalajara, a partir del siglo XIII se distingue un cambio en las características formales de las piezas, con la drástica reducción de las formas nítidamente "islámicas" y el vidriado, cuya presencia se limita al interior de las piezas de mesa. La decoración se circunscribe al empleo de la pintura y especialmente en la tipología de "rejilla" en ocre o negro, que empieza a aparecer de manera significativa en contextos del siglo XII, pero que se expande en el s. XIII (PRESAS et alii., 2009: 811).

Ya en el siglo XIV se producirá la desaparición definitiva de tipos "islámicos", identificándose formas nuevas, entre las que destacan las jarritas con peana y decoración pintada con finas retículas, junto a la perduración de formas de mesa carenadas. Se identifican también ollas de base plana, cuerpo globular, cuello corto y borde exvasado con moldura interior para tapadera, de larga perduración que alcanza los albores del s. XVI. El vidriado sigue siendo marginal y reducido tan sólo a un $9 \%$ del conjunto observado en la excavación del Túnel de Aguas Vivas (Guadalajara), con una reducción drástica del tipo ataifor. Va a ser en la segunda mitad de este siglo (XIV), cuando se va producir la aparición de las piezas vidriadas en verde manganeso y meladas, que representan ya una cuarta parte de las piezas decoradas, coincidiendo con un descenso notable de las formas con pintura. Todo ello, unido al predominio de la vajilla de mesa, especialmente de los platos y escudillas. A lo largo del siglo XV se registran los primeros ejemplares de loza azul, junto al aumento de las piezas vidriadas y las series en verde manganeso.

Esta visión general, es coincidente con los resultados aportados por un reducido número de intervenciones en Alcalá de Henares, entre las que destaca especialmente la del Convento de Mínimos de Santa Ana. La excavación de la crujía septentrional del Convento ha aportado una amplia secuencia estratigráfica, que sirve de nexo entre las distintas áreas de la ciudad por su amplitud cronológica. Todo ello, incide en la necesidad de identificar de manera más precisa la cultura material de los siglos XIII-XV d. C., para poder abordar posteriormente el estudio de las series plenomedievales previas (s. XI-XII d. C.).

\section{LA SECUENCIA ESTRATIGRÁFICA DEL CONVENTO DE MÍNIMOS DE SANTA ANA. ALCALÁ MODERNA}

El Convento de Mínimos de Santa Ana se sitúa en el sector suroccidental del Centro Histórico de Alcalá de Henares (Figura | y 7 ), próximo al recinto amurallado bajomedieval, en las inmediaciones del área inmediata de la Puerta del Postigo o Santa Ana. Se trata de un sector de la ciudad intensamente modificado desde principios del siglo XVI (|5|5-|520), dentro del proyecto de reforma generalizada de la villa, emprendido por el Cardenal Cisneros -Arzobispo de Toledo entre 1495-1517-.

La intervención arqueológica emprendida en él entre finales de 2005 e inicios de 2006, se englobó dentro las tareas de restauración y conservación del propio colegio, que implicaba una remoción de tierras en su ángulo nororiental. Se concentró en dos áreas, con una superficie total de $190 \mathrm{~m}^{2}$. La occidental, 
permitió la documentación de un espacio de enterramiento, vinculado al edificio religioso, que comienza poco después de la construcción de éste y termina abruptamente en los primeros años del siglo XIX. El sector oriental ha sido el que ha aportado una secuencia estratigráfica más amplia. El registro se inicia en un momento indeterminado de la Alta Edad Media, cubierto por un extenso estrato sedimentario, sin cultura material asociada, que separa nítidamente la fase inicial de otra posterior que comienza en la segunda mitad del siglo XIII. A partir de ésta, se produce una continua superposición habitacional, que será alterada por la construcción del convento, durante el último tercio del siglo XVI.

\section{I. La ocupación altomedieval. Primeros indicios (Fase I y II)}

Los indicadores, sobre la ocupación altomedieval son débiles. Se limitan a la excavación de dos depósitos horizontales que se situaban inmediatamente por encima del nivel geológico (u.e. 2233 y 2232) (Figura 15:B y 16). Ambos de naturaleza arcillosa y antrópica, en los que se recuperó material cerámico y óseo. Desgraciadamente, su excavación fue reducida, dada la inmediatez de los depósitos a la parte inferior de la cimentación del convento, y la proximidad del nivel freático, más elevado que en el momento de formación de ambos contextos.

Las escasas dimensiones de la superficie excavada, así como el pequeño lote cerámico, no permiten llegar a conclusiones definitivas, aunque es posible señalar algunos datos significativos. El conjunto cerámico de la unidad 2233 está formado por II fragmentos mayoritariamente a torno, excepto en tres de ellos, en las que se empleó la torneta. Las cocciones son mixtas y en ligera menor proporción oxidantes, de superficies alisadas y acabados con acanaladura al exterior. Las pastas dominantes son anaranjadas. Entre los fragmentos (Figura 17), destacan dos piezas selectas, un fragmento de plato de T.S.H. tardía, y otro de una jarrita de borde redondeado, con asa inmediata a éste y cuello ligeramente abombado hacia el exterior. El grueso del material de la u.e 2232
(Figura 17), que se encontraba cubierto por 2233, es a torno, con un predominio de pastas anaranjadas (60\%), frente a un grupo grisáceo. En cuanto al material selecto de este último contexto, se reduce a un pequeño fragmento de una olla de borde triangular con exvasamiento hacia el exterior, de pastas anaranjadas, desgrasantes micáceos, con el borde quemado, lo que demuestra su uso como forma de cocina. También, un jarro, de pastas anaranjadas, a torno, del que se conserva su base -plana-, y gran parte de su cuerpo globular.

Superpuesto a estos contextos se documentó un extenso estrato, u.e. 2243 (Fase II: Figura 15 y 16) de formación sedimentaria, composición limosa, color anaranjado oscuro, con restos orgánicos, que se han interpretado como resultado de la descomposición de vegetación y totalmente estéril arqueológicamente. Un depósito similar se registra en las intervenciones próximas de la c/Victoria, 2 (ROMÁN GARRIDO, INÉDITO), Seises, 2 (DÍAZ DEL RÍO y ROMÁN GARRIDO, 1996) y Damas (TURINA, 1986a), interpretándose genéricamente como suelo aluvial, tras una paulatina acción fluvial, que amortiza extensamente los contextos altomedievales y tardoantiguos. Los datos alcanzados por la excavación arqueológica en el Convento de Mínimos de Santa Ana, sin embargo, no han permitido obtener de manera inequívoca una secuencia altomedieval. Aunque la evolución cronoestratigráfica sugieren que la formación de los depósitos 2232 y 2233 se situó entre los siglos V-VIII d. C.

\subsection{La ocupación bajomedieval: los límites cronológicos y contextuales (Fase III)}

\subsection{Los orígenes de la Alcalá Bajomedieval ( ${ }^{\text {a }}$ Mitad del siglo XIV). Características y Cultura Material.}

El estrato estéril 2243, que como ya hemos mencionado se extiende por un amplio sector del Centro Histórico, en las proximidades de la Plaza de los Santos Niños, cierra definitivamente el momento de ocupación altomedieval. A lo largo de un momento indeterminado, que de acuerdo a los indicadores estratigráficos se sitúa 
a finales del siglo XIII e inicios del siglo XIV, será parcialmente desmantelado con la apertura de varias fosas, utilizadas como vertederos. Se trata de las estructuras negativas 2223, 2227 (Fase |II-IIII: Figura 18 y 16) y 223। (Fase III-III: Figura 18 y 16), de plantas irregulares y dimensiones medias, de $3 \times 2 \mathrm{~m}$. El conjunto cerámico recuperado sugiere una diferencia cronológica entre ellas. Aunque es posible confirmar el estrato que las amortiza -u.e. 2217-, no existen relaciones estratigráficas directas entre las diversas estructuras negativas (Figura 18). Sin embargo, las u.e.n. 2223 y 2227 podrían ser posteriores a la 2231. En el caso de los rellenos de las dos primeras y su cultura material asociada -uu. e.e. 2222 y $2226-$, tienen estrechas similitudes con el estrato que las cubre (u.e. 2217), fechable en un momento avanzado del siglo XIV.

Los materiales recuperados en la estructura 223I (Fase III-III: Figura 19-20), indican la formación de los rellenos en un momento indeterminado de la segunda mitad del siglo XIII-primera mitad del XIV. Tipológicamente, las ollas presentan cuerpo globular, sin cuello, con hendidura para tapadera, con predominio de las pastas negras o marrones oscuras. También se han recuperado fragmentos de cazuelas/fuentes con vedrío interior, que recientemente ha sido fechado su origen en los inicios del siglo XIV (PRESAS et alii., 2009: 818). No se ha documentado la asociación con estos contextos del tipo escudilla', que ocupa una posición inexistente o marginal, al igual que en el caso de la vecina Guadalajara, que en la secuencia de la primera mitad del s. XIV, representa un exiguo $1 \%$.

Predomina en este momento la decoración con pintura, en bandas o retícula. Aparecen jarras de desarrollo troncocónico e inflexión en la mitad del cuerpo, con asa ligeramente peraltada, y cuello con tendencia recta-en algunas ocasiones estriado-, que tradicionalmente se ha identificado ampliamente en el territorio de Castilla y León (05/62/2230/4), a lo largo del siglo XIII (GUTIÉRREZ GONZÁLEZ y BOHIGAS ROLDÁN, 1989). Aunque aquí se presenta en contextos más tardíos, al igual que en Guadalajara.

También son singulares las pequeñas jarritas de 10 ctms. de diámetro, que tienen como característica principal su cuello y cuerpo globular (05/62/2230/I7 y 05/62/2230/I8), con pintura roja o manganeso en su parte superior. Su cronología es difusa, ya que aunque se sitúa su origen en la segunda mitad del siglo XIII, no son extrañas en contextos que alcanzan el siglo XV.

Se ha recuperado también el cuello de una jarra (05/62/2230/5) con decoración en manganeso sobre engalba blanca, de la que no hemos encontrado paralelos. Aunque su decoración es similar a algunos de los tipos primitivos, de naturaleza geométrica, coronados con dos manos de Fátima esquematizadas, que se consideran iniciales de las series mudéjares levantinas -Paterna-. Aunque se las ha llegado a fechar en la primera mitad del siglo XIII d. C. (MESQUIDA et alii,, 200I), esta periodización no se ha visto todavía ratificada en el caso del centro Peninsular, apareciendo en momentos más tardíos. También son frecuentes los vidriados monocromos, casi siempre al interior. (05/62/2230/86).

Se ha documentado la pared de un fragmento de un gran contenedor (05/62/2230// I0) con decoración estampillada en bandas. En esta pieza es legible el término "al-mūlk". Tradicionalmente se ha considerado piezas de producción almohade (RIERA FRAU et alii., 1998), aunque es innegable su continuidad en los periodos posteriores tanto en territorio cristiano como en el nazarí. Una pieza similar se ha estudiado en las proximidades de la Plaza de Sant Jaume en Barcelona, asociada con monedas de Jaime I, con una contextualización cronológica entre 1 230- 1260 (BELTRÁN, 2009: 645). Debemos considerarla por tanto, una pieza residual en un conjunto de estratos, con una amplia tipología de formas pintadas, que remiten a la segunda mitad del siglo XIII d. C., aunque depositadas aquí en una colmatación del primer tercio del siglo XIV d. C.

\subsubsection{Segunda Mitad del siglo XIV. Caracte- rísticas y Cultura Material}

La primera ocupación bajomedieval, por tanto, es posible situarla en el tránsito entre un periodo final del siglo XIII y la primera mitad del 
XIV, y caracterizada por la apertura de fosasvertederos. Esta primitiva fase, será amortizada por un extenso estrato de naturaleza arcillosa -22 17-que cubriría toda la superficie. La homogeneidad entre este relleno y los materiales recuperados en las estructuras negativas 2223 y 2227 , sugieren que la colmatación se produjo en un momento breve e inmediato, que produjo la definitiva oclusión de las fosas.

El contexto 2217 (Fase III-II) (Figura 21 y 16), de naturaleza areno-arcillosa, de color marrón grisáceo, con inclusiones de cantos, carbón y cal, se extiende por una superficie de $6 \times 5,68 \mathrm{~m}$. con un grosor elevado que alcanza $0,50 \mathrm{~m}$. En cuanto a los conjuntos materiales recuperados en este estrato, destacan las ollas (Figura 22), de cuerpo globular, sin cuello, con hendidura para tapadera, y bordes ligeramente más redondeados que los de fases posteriores. Aunque existe una amplia muestra de platos/ fuentes, las escudillas son minoritarias en la secuencia estratigráfica descrita. Entre ellas destaca un fragmento con marcado repié, y decoración de líneas radiales en azul, desde el centro de la pieza hacia el borde. Aunque no es posible asegurar que se trate de una loza dorada (05/62/22 I7/68), dada su conservación, su similitud con la serie Pula es notable (GARCÍA PORRAS, 2009: 79) con datación inicial en la segunda mitad del siglo XIV.

Esta fecha se ve corroborada por un fragmento de plato de serie azul y dorado (05/62/22/7/I5), con paralelos evidentes con las series levantinas, también recuperadas en el interior de la península, como es el caso de Teruel. Se trata de la conocida serie de coronas radiales dispuestas en torno a un motivo central, que se comienzan a producir a finales del siglo XIV (ORTEGA ORTEGA, 2002: 304). Estas piezas también aparecen contextualizadas junto a formas de loza local (05/62/2217/6I) que demostrarían así una larga continuidad que, efectivamente, de acuerdo a lo descrito por Turina (TURINA, 2001: 807), comenzaría ya en el siglo XIV.También se han documentado conjuntos en verde manganeso-en algunos casos con decoración zoomorfa (05/62/2217/69)-, junto a otras lozas con pigmentación verde.
Sin embargo, lo que destaca de este momento son las decoraciones pintadas concentradas en la parte superior de las formas y en las asas (Figura 23), con porcentajes superiores a lo que se observa para el siglo $\mathrm{XV}$, alcanzando el $10 \%$ del total del conjunto del material cerámico. Estos resultados son coincidentes con los observados en Guadalajara para la segunda mitad del siglo XIV (PRESAS ET alii., 2009: 8||-8|4).

Frente a esta homogeneidad de la secuencia estratigráfica en el primer periodo bajomedieval, caracterizada por la combinación de fosasbasureros y estratos de amortización, a finales de esta fase, en el tránsito con el siglo XV, destaca la documentación de la estructura muraría u.e.m. 2215 (Fase III-I: Figura 2I). Fue realizada en piedra caliza, de dos hiladas, con macizado interior de cantos rodados, con escaso mortero arcilloso, de la que se conservaba 1,20 m. de longitud y 0,56 m. de anchura. See encuentra intensamente arrasada, conservándose únicamente su parte inferior. La falta de asociación de la u.e.m. 22 15, con otros elementos, impiden identificarla como parte de una construcción más amplia, o un cercado. En gran medida, por su destrucción, en las fases inmediatamente posteriores, a lo largo del siglo XV.

\subsection{El tránsito entre la Baja Edad Media y la Alcalá moderna (Siglo XV) (Fase IV). Características y Cultura Material}

A lo largo del siglo $X V$, se observa una continua actividad en el área, empleándose como espacio de almacenaje y área de vertido, al mismo tiempo que se produce un progresivo aumento de la cota de frecuentación. Hemos insistido en que se trata de una situación generalizada en todo el sector occidental de la villa, a lo largo del siglo $\mathrm{XV}$, sin que sea todavía posible afirmar si coincide con una posición marginal de este sector en el contexto urbano, o con una definición parcelaria mucho más lenta de lo que hasta ahora se conocía. Román Pastor (ROMÁN PASTOR, 2004: 520-522) subraya la escasez de referencias sobre la estructuración del viario y su denominación, con anterioridad a la 
segunda mitad del siglo XV. Todo ello refuerza una imagen disgregada y poco consolidada, con un crecimiento urbano definitivo a finales de esta fase.

La primera mitad de la centuria corresponde con un esquema evolutivo, similar al de las fases previas del siglo XIV, alternándose la apertura de fosas-vertederos y amortizaciones, aunque con una mayor brevedad de éstas. El estrato 2217, que se ha fechado a lo largo de la segunda mitad del siglo XIV, se encuentra cortado por dos estructuras negativas u.e. 2214 de 4,72xI,53 m. y - I,08 m. de profundidad y 2221 de $2,72 \times 2,10$ m., ambas de planta irregular. Apenas fueron desmanteladas durante la fase de cubrición posterior-u.e. 2212-, lo que supone un relleno inmediato sobre ellas, sin que implique una remoción del terreno, al mismo tiempo que se produce a un aumento de la cota de tránsito o de frecuentación del área. En la cultura material cerámica recuperada en estas fosas (Figura 24 y $21^{7}$ ), aparecen las ollas globulares con hendidura para tapadera, sin cuello, con borde moldurado, o con marcado exvasamiento hacia el exterior. Entre los fragmentos decorados se recuperaron algunos pintados con líneas oblicuas y disposición reticulada, con empleo de pigmentación en negro y rojo. Aunque las lozas y las formas de mesas son menos frecuentes que en periodos posteriores, se documentó un reducido lote, con esmalte blanco y decoración en verde, geométrica, correspondiente con formas abiertas, posiblemente de origen aragonés (ORTEGA ORTEGA, 2003; MARTíNEZ CAVIRÓ, 1983).

En el estrato que amortiza las fosas, -2212 (Fase IV-II: Figura 25 y 16)- de naturaleza arenoarcillosa, con restos de cal, carbones, cantos de cuarcita, y relativamente compacto, se observa un importante cambio con respecto a los conjuntos materiales anteriores. Las piezas con decoración verde-manganeso alcanzan un porcentaje en torno al $5 \%$, al igual que las pintadas al exterior. Es ahora cuando se observa la llegada de piezas de producción alfarera (Figuras
26 y 27) levantina 05/62/2212/312 (PASCUAL y MARTí, 1986), con conjuntos en verde manganeso de amplia distribución en el centro peninsular como el plato fuente 05/62/22/ I/I58, frecuente en contextos de Valladolid, Madrid, Ágreda y Toledo (TURINA, 200I, pp. 808-816; VILLANUEVA, 1998). Sin embargo aquí con una cronología que consideramos posterior, y difícilmente anterior al primer tercio del siglo XV.

Junto a ello, se produce la continuidad de un importante conjunto de formas de cocina, que desaparecerán a finales del siglo $\mathrm{XV}$ e inicios del XVI. Se caracterizan por su forma muy cerrada, de pastas marrones, desgrasantes micáceos, a torno, de bordes moldurados, con engrosamiento al exterior, hendidura para tapadera, y mayoritariamente con ausencia de cuello (Figura 27).

También se han documentado escudillas con una línea indicada, que marca una ligera carena en el desarrollo del cuerpo, y que se diferencia de los tipos redondeados-globulares más comunes de la centuria siguiente. Es en este momento también cuando las piezas de loza dorada y azul tienen una mayor presenciaespecialmente las "clásicas" (05/62/22/2/348) (LERMA et alii., 1986: p. 190)-, junto a series con decoración en verde, de posible producción aragonesa (05/62/22/2/352). Los conjuntos analizados muestran también una situación minoritaria de las series blancas (Figura 28), que tendrán un crecimiento brusco a partir de principios del siglo $\mathrm{XVI}$.

\subsection{La consolidación urbana (Finales S. XV).}

El aspecto más novedoso, sin embargo, es la comprobación de la definitiva consolidación de la trama urbana a finales del siglo XV. La construcción de un conjunto de viviendas en la Plaza de Santa Ana, supuso un proceso generalizado de articulación del parcelario en este sector de la ciudad. El levantamiento de edificaciones en áreas inmediatas, tal como podemos observar en intervenciones recientes

\footnotetext{
7 Esta fosa se encuentra en el tránsito entre el siglo XIV y XV, siendo difícil ahondar más en su periodización.
} 
de la C/Seises, 2 (ARIAS CABEZUDO, 2006b) y Cl Tercia 3-5 (ARIAS CABEZUDO, 2006a), muestran una periodización análoga. Pero a la consolidación urbana se le unen otros elementos en la formación de los depósitos arqueológicos, que subrayan que a finales del siglo $\mathrm{XV}$ las pautas de ocupación estaban cambiando, con respecto a las que habían caracterizado al área hasta ese momento. La construcción de la vivienda y almacenes a finales del s. XV, supuso la alteración en los procesos formativos de la estratigrafía, que hasta entonces se había caracterizado por la paulatina superposición y horizontalidad (Figura 16).

Las estructuras fueron levantadas sobre el desmantelamiento parcial de algunas fosas-u.e. 2206 (Fase IV)-y su relleno u.e. 220I, que se encontraban vinculadas al suelo 2126 (Fase IV-II: Figura 29). Con unas dimensiones de $1 \mid$, 7×5,7 $\mathrm{m}$. es anterior, por tanto, al conjunto de edificaciones que caracterizarán al área durante la primera mitad del siglo XVI, pudiendo identificarla con una ocupación que alcanzaría el último tercio del siglo XV d. C., sin que hayamos localizado estructuras murarías asociadas o elementos delimitadores espacialmente.

Los materiales asociados al desmantelamiento de la fosa $2206^{8}$ y su relleno 220I (Fase IV-III: Figura 30-3I), han permitido recuperar platos con decoración verde-manganeso al interior, y fragmentos de loza dorada, con motivos geométricos en bandas con semicírculos y franjas trapezoidales en dorado, pertenecientes posiblemente a la segunda mitad del siglo XV. Son mayoritarias las formas de mesa. Aparece la decoración en palmetas de los conjuntos alcalaínos, en este caso, en verde frente a las piezas en manganeso, lo que podría indicar la existencia de varios alfares o procedencias. Aunque no son tampoco inexistentes las combinaciones de ambas pigmentaciones.

También jarras de cuerpo globular, borde recto y asas peraltadas engrosadas en su unión con el cuerpo (05/62/220 I/ / / 6). Pero en cuanto a los conjuntos se empiezan a observar los primeros cambios, al menos en los acabados de las piezas de mesa con respecto a los materiales vistos en fases anteriores (s. XV). Las lozas alcalaínas representan un porcentaje que no alcanza el $2 \%$, al mismo tiempo que se observa una reducida presencia de los conjuntos de loza dorada-aproximadamente el 5\% del total de los conjuntos esmaltados-.

\subsection{El periodo anterior a la cons- trucción del convento: las viviendas del siglo XVI. Rasgos constructivos y cultura material (Fase V)}

El conjunto de las viviendas (Figura 7) que se situaron en el solar del actual convento de Mínimos de Santa Ana, conformaban espacios domésticos con una estructura abigarrada, habitados por campesinos o agricultores, sometidos a censos y arrendamientos. Así lo muestran las distintas escrituras de compraventa ejecutadas por las distintas órdenes religiosas, en sus deseos de establecerse en este área de la villa. Afortunadamente, el grabado de Anton Van den Wyngaerde de 1565, nos permite intuir la estructura del conjunto con anterioridad a su demolición a partir de I580. A lo largo de la primera mitad del siglo XVI Bartolomé Santoyo-secretario de Felipe II- y Leonor de Mascareñas-aya del monarca- consiguieron gran parte de las propiedades que luego ocupará el convento. En realidad, el proceso de imposición de la estructura urbana conventual, no se habría producido sin la colaboración y promoción que realizó la nobleza, estrechamente ligada al funcionamiento de la administración del Estado, y deseosa de alcanzar el reconocimiento y la aquiescencia de la Iglesia.

El conjunto de viviendas corresponde a una extensa fase de ocupación, de la que hemos encontrado varias superposiciones, que demuestran la existencia de una primitiva construcción (finales del s. $\mathrm{XV}$-inicios del $\mathrm{XVI}$ ), reformada profundamente en un segundo momento (mediados del siglo XVI). De este conjunto se han documentado varios elementos (Figura 16), siendo el más destacado, sin duda, la estructura

8 Esta fosa sería desmantelada parcialmente coincidiendo con la construcción de la estructura muraría u.e.n. 2199. 
muraria, u.e.m. 2199 - de 6,30 m.de largo y $0,60 \mathrm{~m}$. de ancho (Figura 29). Del muro se han podido observar dos fases constructivas, por un lado, un zócalo calizo, formado de dos hiladas, de sillarejo, y relleno interior de mampuestos de cuarzo, sobre el que se ha levantado posteriormente varias hiladas, compuestas mayoritariamente por cantos, encima de las cuales se articulaba un alzado de tapial. Las fosas con relleno de yeso, vinculadas a la construcción del convento se asientan directamente sobre él, y en algunos casos lo rompen, lo que refuerza el planteamiento de una intensa demolición iniciada en I580. En el último periodo de uso del muro, se le adosa en su lado septentrional un refuerzo en tapial, junto a mampuesto calizo, de $0,56 \mathrm{~m}$. que acabaron conformando una estructura de casi I, 10 m (u.e.m. 2083-Figura 32). A ambos lados de la estructura fue posible documentar dos pavimentaciones. En el lado sur un empedrado-ue. 2084-, formado por cantos de río de de 0,15 m. de tamaño medio, que sufrió directamente el arrasamiento de la nueva construcción, junto a un suelo en el lado septentrional (uu.ee. 2067, 2117 y 1085), formado por arcilla, ladrillo y teja, aglutinado con abundante cal y muy compacto, que podría corresponder a un espacio interior.

Es aquí, al norte, donde la vivienda muestra una superposición estratigráfica que señala que la formación del pavimento de cal (2067), se apoyaba sobre otro previo-u.e. 2095 (Figura 33)-, compacto, de color marrón, con abundantes nódulos de cal por debajo del anterior 2067, y previo al refuerzo murario. Ligeramente anterior a 2095 existe otra ocupación de similares características (u.e. 2120). Aunque no hemos podido observar la relación de esta última y el muro 2199, su formación se produjo contemporáneamente a la construcción de la estructura muraría.

\subsection{La Cultura Material}

En cuanto a la cultura material cerámica que aparece asociada a la fase de ocupación que representa esta vivienda, refleja el tránsito entre las producciones propias del siglo XV y la consolidación definitiva de las modernas. El conjunto cerámico de la fase más tardía de ocupación de la vivienda (Figura 34-35), es similar a la que se observa en la Fase $\mathrm{VI}$ -momento de construcción del conventolo que ratifica la proximidad temporal entre ambas fases. Está integrado mayoritariamente por forma cerámicas de mesa-escudillasprimando como acabado el esmaltado blanco sin decoración, con diámetros entre 12-16 ctms. En cuanto a las series decorativas vuelve a aparecer la loza "alcalaína", aunque en una variante poco común (05/62/2067/2I). Es frecuente también el vidriado interior y exterior de las piezas, en algunos casos esmaltados, en verde $^{9}$, que recuerdan a las series turolenses de los siglos XV-XVI d. C. También aparecen aquí piezas pintadas en negro, o rojo a modo de líneas junto a otras en verde-manganeso. Entre las lozas debemos subrayar la presencia de la serie en dorado y azul, reproduciendo motivos geométricos al interior, y de reflejo dorado y palmetas estilizadas con círculos al exterior (05/62/2067/53). Su origen, vinculado a la serie geométrica de Paterna-Manises, se fecha con posterioridad a la segunda mitad del siglo XV d. C.

Dentro de los conjuntos, dominados por el tipo escudilla y plato, se observa una clara residualidad de los conjuntos en loza dorada y azul, que no representan ni el $2 \%$ de las piezas analizadas, y un predominio de los clásicos conjuntos exclusivamente en blanco. Estos porcentajes subrayan la limitada representatividad de las producciones levantinas ya en el siglo XVI.

La cultura material cerámica asociada al estrato 2095 (Fase V-II), cuya formación situamos a finales del siglo $\mathrm{XV}$ o inicios del $\mathrm{XVI}$, tiene claras similitudes con las fases posteriores del registro, aunque sin embargo cuenta con algunas pequeñas variaciones, indicativas de los cambios que se observan ya en el tránsi-

\footnotetext{
9 Las producciones esmaltadas mayoritariamente blancas, suelen aparecer acompañadas de conjuntos en negro-gris, que consideramos son resultado de procesos de cocción erróneos. Las series en verde, son sin embargo pequeños lotes, con tonalidad amarillenta, sin que hayamos podido identificar de manera definitiva su procedencia.
} 
to entre el siglo $X V$ y $X V I$. Predominan aquí (Figura 36) las piezas esmaltadas en blanco-en la forma escudilla al interior-, unidas con piezas con decoración en verde manganeso. Algunas de estas últimas, con líneas de palmas, podrían tener relación con los tipos de platos/fuentes que se atribuyen a la producción local (TURINA, 2001: pp. 801-822) (05/62/2095/28). Entre la loza predominan las clásicas series en azul, con decoración en palmetas fechadas genéricamente en la segunda mitad del siglo XV d. C (05/62/2095/I5) (LERMA et alii., 1986: 183-203). La unión entre estos materiales, con series verdemanganeso suele ser frecuente en áreas como Guadalajara. pero también en excavaciones del núcleo urbano alcalaíno, como la intervención en el antiguo Colegio de Jesuitas, dándoles una cronología ligeramente anterior al siglo XVI (BENITO LÓPEZ et alii., 200I).

Previo a la pavimentación u.e. 2095 en cuanto a su formación y posiblemente ligado a la primitiva construcción de la vivienda, se ha documentado el estrato u.e. 2I 20 (Fase V-III; Figura 37-38), de color grisáceo y naturaleza ligeramente arcillosa, que también corresponde con un nivel de frecuentación. Su cultura material muestra una gran similitud con la de las otras fases de la vivienda, salvo por la presencia de formas pintadas con decoración en retícula y escudillas esmaltadas en blanco con asas de orejetas polilobuladas (05/62/2 120/39). Las lozas, muy deterioradas, conservan líneas en azul, unas en bandas y otra formando arcos, que podrían vincularse a la serie geométrica de la loza gótico-mudéjar, fechable a lo largo del siglo XV (GARCÍA PORRAS, 2009).

\subsection{Los orígenes de la fundación y el contexto urbano en la Alcalá de los siglos XVI-XVII (Fase VI)}

En 1578 se produce la llegada de la Orden de los Mínimos de Santa Ana a este sector de la ciudad, tras el deseo de B. Santoyo, propietario de gran parte de los terrenos, de cederles parte de sus propiedades, a cambio de asegurarse que la nueva fundación conventual luciera sus blasones, y su familia ocupase un lugar preeminente en la nueva iglesia. La construcción de ésta se inicia en 1580, y finalizará en un periodo de tiempo breve-1593-, lo que demuestra la capacidad económica del impulsor.

El complejo colegial se inició mediante el levantamiento de la crujía sur del claustro que ejercerá también de fachada de la Plaza de la Victoria, y que se completará en I6I4 (ROMÁN PASTOR, 1979), con el cierre tanto al este como al norte. La construcción del convento significó una reordenación del parcelario bajomedieval de estas áreas, a la que se sumaba el vecino palacio de la familia impulsora, situado al este. A lo largo de los siglos XVII y primer tercio del XVIII, la orden de Mínimos irá asumiendo parcialmente el control del actual callejón del Hospital, denominado posteriormente como Plaza del Herrezuelo.

La excavación efectuada en la crujía norte del patio principal, ha aportado datos sobre el momento formativo del complejo. Del estudio de la pared septentrional de la iglesia, es posible afirmar que inicialmente, ésta ejerció de fachada, encontrándose por tanto, la cabecera del templo exenta, hasta su definitiva inclusión en el complejo colegial. La intervención arqueológica ha supuesto la confirmación de las técnicas constructivas y el proceso edificatorio del conjunto. La cimentación, formada por mampuesto calizo, trabado con mortero de cal, alcanza los tres metros de alzado en el área oriental. Ésta se colocó en una profunda zanja, sin que existiese una remoción de los depósitos arqueológicos a ambos lados de la estructura. Era significativamente más ancha que el muro superior, identificándose su unión con el término de "aceras" que señalan los textos (ROMÁN PASTOR, 1979: 100), y que debían corresponderse con el doble paramento de la estructura. Sobre ellas, con una menor superficie de contacto, se levantaban propiamente las paredes de la crujía. Asociado al levantamiento del muro, se han localizado un grupo de estructuras negativas de pequeñas dimensiones -uu.ee.nn. 2810, $2156,2811,2807=2158,2812,2808=2160$, $2813,2809=2192$ (Figura 39)-. Posiblemente unidas a tareas de apuntalamiento del conjunto a medida que éste se iba levantando, de 0,20 $\mathrm{m}$. de diámetro y planta circular o alargada. Esta fase constructiva (Fase VI-I: Figura 16), documentada mayoritariamente en el muro 
norte de la crujía, plantea algunos interrogantes sobre la verdadera fecha de construcción del conjunto, ya que por debajo de ella, se ha localizado otra fase edificatoria anterior (Fase VI-III). En esta última se observa otro conjunto de estructuras negativas, en este caso de planta trapezoidal de 0,40 m. -uu.ee.nn. 2 I 12, 2079, $2073=2101,2072=2099,2054,2135,2134$, 207I (Figura 39)-, que se han relacionado con la colocación de andamiaje.

En cualquier caso, entre ambos niveles de estructuras negativas existe un estrato de amortización o relleno, denominado u.e. 2063 (Fase VI-II), en el que se ha recuperado una pequeña ocultación numismática formada por nueve piezas de dos maravedís, acuñadas bajo el gobierno de Felipe II-I556-1598- y emitidas en Burgos y Cuenca (CASTRO PRIEGO, 20I I) (Figura 40). En un estrato similar tanto en su posición como en sus características, en el área occidental, se recuperó otra moneda, en este caso un real de plata acuñado en 1590. Todo ello, ha permitido considerar que, tal vez, la construcción de la crujías se iniciaron con anterioridad a la segunda década del siglo XVII, tal como ha defendido Román Pastor (ROMÁN PASTOR, 1979).

\subsection{La Cultura Material}

Asociado a la construcción del complejo conventual, se ha recuperado un importante conjunto material que permite observar las transformaciones que se están produciendo en el repertorio cerámico a principios del siglo XVII-momento de expansión de los alfares talaveranos y locales-, y la desaparición de los tipos que habían caracterizado la segunda mitad del siglo XV y el s. XVI. Si la u.e. 2063 corresponde con un extenso estrato de relleno o amortización depositado durante el proceso constructivo del convento (finales del s. XVIinicios del XVII), la u.e. 2048 representa la finalización de éste, y el comienzo definitivo de la existencia del Colegio ya, en el siglo $X V I I$. Es significativa la continuidad en estos estratos bien fechados- entre los siglos XVI y $X V I I-$ de formas cerámicas tradicionalmente identificadas con la segunda mitad del siglo $X V$, que demuestran aquí su pervivencia, en un momento de multiplicación material de los tipos "modernos" identificados tradicionalmente en el área central de la península con los alfares "talaveranos' ${ }^{\prime 0 " . ~ A u n q u e ~ b a j o ~}$ esta última denominación se esconden vajillas, especialmente de las formas de mesa de mayor consumo, producidas a lo largo del Reino de Castilla, en el núcleo toledano, entre otros. A todo ello, se suma en el caso de Alcalá la producción de cerámicas locales, definidas por Turina (TURINA, 200I) como características del siglo XIV-XV, pero que están presentes en la cultura material que integra lo depósitos de esta fase, especialmente las uu.ee. 2063 y 2048 de manera relevante-1 I\% de las series esmaltadas-, y que por tanto se sitúan cronológicamente en un momento mucho más tardío, lo que parece señalar una extensa perduración de las producciones y tipos locales.

En un porcentaje muy reducido también se han recuperado piezas de loza dorada. En el caso de la ue. 2063, se registraron escudillas de la serie "Ave María", con motivos de flores de puntos (MARTíNEZ CAVIRÓ, 1983: I36-137), que tradicionalmente se consideran producidas entre |420-|440 d. C., y que, en este caso, aparece, al igual que los conjuntos "alcalaínos" en un contexto mucho más tardío, gracias a la información que nos proporcionan los hallazgos monetarios anteriormente mencionados. La documentación de tipos de la serie "Ave María" es conocida en otros puntos del Centro Histórico de Alcalá de Henares, en contextos fechados en la segunda mitad del s. XV -C/ Libreros, 36 (ROMÁN GARRIDO y DÍAZ DEL RíO, 1996)-.

\footnotetext{
10 Tradicionalmente se acepta que las producciones esmaltadas blancas en el ámbito central de la Península tienen su origen en la segunda mitad del siglo XV d. C., y comenzaron una amplia difusión durante la primera mitad de la centuria siguiente. En algunos casos, estas series, correspondían a manufacturas específicas, acompañadas de símbolos o referencias a una determinada comunidad religiosa, GONZÁLEZ ZAMORA, C., Las lozas de Talavera y su entorno a través de una colección, Madrid, 2004: 94-95; MARTíNEZ CAVIRÓ, B., Cerámica de Talavera, Madrid, 1984. Su frecuente presencia en contextos arqueológicos no ha venido aparejada con una sistematización que pueda aportar datos sobre continuidades productivas o perduraciones.
} 
El grueso de las formas de las dos unidades principales de este periodo (Figura 4 I-43) está integrado por el tipo escudilla-con diámetros entre los 14 y 17 cts.- y plato fuente, con unas dimensiones en torno a los 19 cts., representando el $60 \%$ de los tipos identificados. En esta fase se produce la multiplicación de los grupos funcionales que no sólo se limitan a la series de mesa y cocina, sino que también están representados aquéllos vinculados al aseo personal, o actividades no directamente relacionadas con el consumo y preparación de alimentos. Frente a los porcentajes de la vajilla de mesa- a los valores anteriores, hay que sumar elementos menos frecuentes como las salseras y platillos-, el conjunto de piezas vinculadas a tipos de cocina no supera el 15\% del total.

En cuanto a los acabados, entre los conjuntos vidriados, es posible observar el predominio de las series vidriadas meladas y marrones, combinándose en muchas ocasiones con trazos negros u oscuros, que son predominantes en los conjuntos con esta técnica de fabricación recuperados en contextos del siglo XVI d. C. El vedrío no cubre en algunas ocasiones la totalidad de la pieza, limitándose a la parte superior de ésta y los elementos sustentantes. De mayor complejidad es el análisis de las piezas con decoración pintada. Tienen una extensísima perduración desde los contextos plenomedievales, apareciendo aquí asociadas a depósitos de inicios del siglo XVII, aunque su presencia no supera el $2,77 \%$ del conjunto total.

Todo ello, permite concluir que la cultura material que caracteriza el momento constructivo inicial del complejo conventual, se caracteriza por el predominio destacado de las formas de mesa, frente a series en cocina. La prevalencia del tipo escudilla/cuenco unido a la generalización de las producciones en loza blanca, caracterizarán este periodo, junto a tipos en vedrío melado, presentes en mayor medida que en periodos previos, frecuentes en formas de mesa, almacenamiento o aseo personal. Pero sobre todo se observa la práctica desaparición de las series bajomedievales-especialmente la loza levantina-. Todo ello, indica la aparición de grandes conjuntos alfareros-es el caso de los centros talaveranos- capaces de alimentar un amplio mercado, al mismo tiempo que se produce una rápida homogeneización tipológica y técnica en los principales centros productores peninsulares, que no sólo alimentarán el consumo interno, sino también la exportación a los territorios coloniales americanos.

\section{CONCLUSIONES}

La configuración de la Alcalá Medieval sigue todavía aportando una visión fragmentaria. La existencia de dos núcleos próximos y la promoción de la nueva villa a través de los deseos señoriales de beneficiarse de la vía de comunicación inmediata, desde inicios del siglo XIII, pudo ser un proceso más lento de lo que hasta ahora se ha interpretado. Las dificultades pueden haber sido diversas, junto a la proximidad de dos centros inmediatos en crecimiento: Guadalajara y Madrid.

Parte de las respuestas no sólo se encuentran en el Centro Histórico, sino también en la vecina Alcalá la Vieja, en la que las actuales excavaciones describen una amplia secuencia entre los siglos XIII-XV. La fortaleza debió de estar ocupada y mantenida por el Arzobispado de Toledo, con un celo mayor de lo que se conoce por las fuentes textuales. iSe mantuvieron sus arrabales a lo largo del siglo XIII-XIV, al mismo tiempo que se consolidaba el burgo de Santiuste? Torres Balbás recogió una oscura referencia que aporta luz sobre esta cuestión, en un breve inventario de las casas arzobispales fechada en $1276^{\prime \prime}$ y que señala la existencia a finales del siglos XIII e inicios del XIV de dos centros diferenciados, con mercados propios. De su lectura y de los resultados de la investigación arqueológica, se vislumbra un panorama nuevo en la historia

\footnotetext{
I I "la huerta que solie tener por el Arzobispo Don Rodrigo (liménez de Rada) que es cerca del mercado uieio en Alcalá la vieia... et de la otra parte la carrera que salle del mercado vieio et va a la calçada. et' De otra parte las casas de Bogón" TORRES BALBÁS, L.: "Complutum, Qal'at 'Abd al-Salām y Alcalá de Henares", Boletín de la Real Academia de la Historia, CXLIV, Madrid, I959: I67-I68.
} 
de la ciudad, que arranca hacia el I 300 con la definitiva imposición territorial de la residencia arzobispal, frente a la vieja fortaleza.

No hemos pretendido realizar un estudio exhaustivo de la cultura material cerámica (Figura 44)-que merece un análisis más pormenorizado-, siendo el leitmotiv de este trabajo la descripción de la secuencia estratigráfica obtenida en el Convento de Mínimos de Santa Ana, así como la transformación de los contextos medievales. Junto a ello, una visión evolutiva de Alcalá de Henares a lo largo de la Edad Media, que a través de indicadores arqueológicos fragmentarios, plantea un panorama histórico diferente a lo señalado en los diversos estudios, que se han centrado en el desarrollo urbano (ROMÁN PASTOR, 2004). Es cierto que estos últimos, se apoyan fundamentalmente en un corpus documental reducido y en una interpretación evolutiva a partir del parcelario actual que entraña riesgos interpretativos. Estas propuestas no habían sido hasta ahora contrastadas arqueológicamente, en gran medida como resultado de la ausencia de estratigrafías fiables y descritas suficientemente a lo largo del valle del Henares, salvo recientes estudios de síntesis (OLMO ENCISO, 2002; PRESAS et alii, 2009).

El complejo religioso de Santa Ana levantado a finales del siglo XVI, supuso la culminación de un intenso arrasamiento y transformación de la superficie, que rompe con los procesos deposicionales de cronología anterior- ss. XIV$X V$-, y una primera fase urbanizadora del sector suroccidental de la villa, en el último tercio del siglo XV. De la estratigrafía se deduce también la superposición de varias edificaciones previas a la consolidación del proyecto conventual, a lo largo de la segunda mitad del siglo XV e inicios del XVI. De acuerdo a la representación de Anton Van den Wyngaerde (I565) del parcelario que se vio afectado por la posterior construcción de la orden de Mínimos, es posible todavía vislumbrar el edificio que ocupaba las áreas de excavación 1000 y 2000 (Figura 7). Incluso la construcción con orientación o-e de la crujía colegial, tiene aspectos comunes con lo representado, en este caso, en el extremo septentrional de un amplio espacio abierto de una vivienda o almacén de dos pisos, con acce- so a un callejón que desembocaba en la Calle de los Coches. ¿Se trata de la vivienda de la que describimos su secuencia ocupacional en la FaseV? Posiblemente la respuesta sea afirmativa, lo que demostraría por otro lado, que si bien la iglesia conventual, aprovechó principalmente los espacios abiertos del entramado urbano, el Colegio posterior, tuvo que adaptarse a los límites de las parcelas coincidentes en gran medida, con las edificaciones bajomedievales.

Los resultados aportados por la secuencia estratigráfica del Convento de Mínimos es coincidente también con la de otras áreas próximas, especialmente tras las excavaciones de la CNictoria, y Seises n 2 (DÍAZ DEL RÍO y ROMÁN GARRIDO, 1996). El conjunto de ellos permite confirmar que, al menos para el sector suroccidental de la ciudad, la ocupación urbana no parece consolidarse hasta un momento avanzado de la segunda mitad del siglo XV.

Sin embargo, la excavación del Convento de Mínimos también señala otros datos interesantes sobre la producción cerámica y especialmente de la difusión de determinadas series entre los siglos XIII- XVI. En este sentido, debemos incluir la expansión de las lozas blancas, que alcanzan un crecimiento exponencial a partir de inicios del siglo $X V \mathrm{~V}$, aunque frecuentes ya en la segunda mitad del siglo XV. La primera mitad del siglo $\mathrm{XV}$, en cambio, indica la difusión de la loza, en concreto los conjuntos "alcalaínos", la levantina y los platos en verde manganeso, con un periodo de crecimiento que comienza a mediados del siglo XIV d. C.y que se extienden a lo largo del $X V$, para reducirse drásticamente a finales de la centuria.

Uno de los elementos recurrentes en la investigación ha sido, sin duda, la posible producción de un tipo de loza a lo largo de los siglos XIV y XV en Alcalá de Henares, de escaso alcance regional y reducido volumen que fue descrita por Turina (TURINA, 1985) a partir de una intervención arqueológica en la C/ Santiago. Con estos elementos iniciales, a los que se sumaban actuaciones parciales en otros puntos de la ciudad, tanto en el núcleo central de crecimiento durante los siglos XII-XIV, como en áreas consolidadas a partir del siglo $\mathrm{XV}$, per- 
mitieron aportar un primer esquema evolutivo (TURINA, 200 I), encuadrándose bajo el ambiguo término de "cerámica mudéjar 12". Quedan por resolver todavía numerosas dudas sobre estas producciones, especialmente de su expansión, o de los posibles talleres ubicados a lo largo del valle del Henares. Los resultados estratigráficos confirman su origen a lo largo del siglo XIV, posiblemente a mediados de éste -u.e. 2222-. Lo que queda fuera de toda duda es que variantes de estas piezas, caracterizadas por un mayor esquematismo, siguen documentándose a lo largo del siglo XVI, momento de mayor representatividad porcentual, y los inicios del siglo XVII. La difusión por el territorio inmediato de estas series es todavía desconocida. No es frecuente su aparición en contextos medievales de Madrid, aunque se han recuperado conjuntos en el Centro Histórico de Guadalajara (BENITO LÓPEZ y RICO SÁNCHEZ, 2002).

\section{BIBLIOGRAFÍA}

ALDECOA QUINTANA, A., (2008): Memoria de la actuación arqueológica para la construcción de vivienda unifamiliar en Calle Cervantes n8, Alcalá de Henares (Madrid), 2008, Archivo Documental Museo Arqueológico Regional de la Comunidad de Madrid.

ARIAS CABEZUDO, P., (2005): Memoria final de la Excavación en la Calle Santiago, 22 Alcalá de Henares (Madrid), Archivo Documental Museo Arqueológico Regional de la Comunidad de Madrid, Sig. 66/2005.

-(2006a): Informe Final de la intervención arqueológica en el solar situado en la Calle Tercia n 3 y 5 de Alcalá de Henares Madrid, Archivo Documental Museo Arqueológico Regional de la Comunidad de Madrid.

-(2006b): Memoria Final de la excavación arqueológica en la calle Seises, I de Alcalá de Henares, Archivo Documental Museo Arqueológico Regional de la Comunidad de Madrid., 2006, Sig. 2005/46, inédita.

BELTRÁN DE HEREDIA, J., (2009): "Pisa arcaica decorada en verde y/o manganeso de Barcelona y cerámica vidriada. Un contexto de la primera mitad del siglo XIII", Actas del VIII Congreso Internacional de Cerámica Medieval en el Mediterráneo, pp. 635-65I, Ciudad Real.
BENITO LÓPEZ. J. E:; GARCÍA-VALERO, M.A. y MARTÍNEZ NARANJO, J. P. (200 I):" "Actuación arqueológica en la Iglesia de Santa María de Alcalá de Henares (Madrid)",en De La Hoz Martínez, J. D. (dir.), La Antigua Iglesia del Colegio Máximo de la Compañía de Jesús en Alcalá de Henares, actual parroquia de Santa María, pp. 227-239, Madrid.

BENITO LÓPEZ, J.E., y RICO SÁNCHEZ, M.T., (2002): "Excavación arqueológica en la Ermita de Nuestra Señora de la Antigua (Guadalajara)", Actas del I Simposio de Arqueología de Guadalajara, pp. 725-738, Madrid.

CERVERA VERA, L. (1987): El conjunto urbano medieval de Alcalá de Henares y su calle Mayor soportalada, Alcalá de Henares.

CASTILLO GÓMEZ, A., (1989): Alcalá de Henares en la Edad Media.Territorio, sociedad y administración | | | 8-15/5, Alcalá de Henares.

CASTRO PRIEGO, M. (201 I): La problemática del Registro Arqueológico de Alcalá de Henares y la aplicación de Nuevas Tecnologías, Tesis Doctoral, Universidad de Alcalá, Julio 2011 .

-, (20 I I): "La evolución urbana de Alcalá de Henares entre los siglos XIV-XVII: los hallazgos numismáticos", XIV Congreso Nacional de Numismática, 899-9II, Madrid.

COLL CONESA, J., (2000):" "La evolución de la vajilla cerámica: de los alfareros mudéjares a moriscos", De la Edad Media al siglo XVI, Jornadas Históricas del Alto Guadalquivir $n^{\circ} 10$, pp. 63-95, Jaén.

- (2008): "La loza decorada en España", Ars Longa, 17, pp. $|5|-\mid 68$.

- (2009): La Cerámica Valenciana. Apuntes para una Síntesis, Valencia.

DÍAZ-DEL RÍO ESPAÑOL, P. y ROMÁN GARRIDO, L., (1996): "Sobre los orígenes del Alcalá de Henares medieval: excavaciones en el Colegio de San Justo y Pastor", Reunión de Arqueología Madrileña, pp. I19-I22, Madrid,

FITA COLOMÉ, F., ( 885$)$ : "Bula inédita de Honorio II", Boletín de la Real Academia de la Historia, vol. VII, pp. 335-346, Madrid.

GARCÍA FERNÁNDEZ, J., (1952): "Alcalá de Henares. (Estudio de Geografía Urbana)", Estudios Geográficos, vol. XIII, n 47, pp. 299-355, Madrid,

GARCÍA LLEDÓ, F. J., (2003): "Arqueología Medieval en Alcalá", Alcalá de Henares, páginas de su Historia. XII Curso de Historia, Arte y Cultura, pp. I I-22, Alcalá de Henares,

GARCÍA LLEDÓ, F. J., y MENDUIÑA GARCÍA, R.C., (2008): "Actuación Arqueológica realizada en la Lonja de la Catedral-Magistral de Alcalá", Anales Complutenses, XX, pp. I53-172, Alcalá de Henares

12 TURINA GÓMEZ,A., "Nuevos datos sobre la cerámica mudéjar en el centro peninsular", V Congreso de Arqueología Medieval Española, T. II,Valladolid, 200 I, pp. 808-809: "Hemos visto que las comunidades mudéjares que se establecen en diferentes puntos del centro peninsular parten de una misma base, pues los materiales del siglo XIII se caracterizan en diferentes puntos geográficos por la homogeneidad del repertorio cerámico, tanto en lo que se refiere a la técnica, como a la morfología. Esto es lógico, pues se trata de artesanos procedentes del sur que llegan a esta zona con el mismo bagaje técnico". 
GARCÍA PORRAS, A. (2009): La cerámica en azul y dorado valenciana del siglo XIV e inicios del XV, Valencia.

-(20 I 2a):"El azul en la producción cerámica bajomedieval de las áreas islámica y cristiana de la Península Ibérica", Atti del IX Congresso Internazionales sulla Ceramica Medievale nel Mediterraneo, pp. 22-29, Firenze.

GONZÁLEZ, J., (1975): Repoblación de Castilla la Nueva, Guadalajara,

GONZÁLEZ ZAMORA, C., (2004): Las lozas de Talavera y su entorno a través de una colección, Madrid.

GUTIÉRREZ GONZÁLEZ, J. A., y BOHIGAS ROLDÁN, R., (1989): La cerámica medieval en el Norte y noroeste de la Península Ibérica. Aproximación a su estudio, León.

LERMA, J.V., MARTÍ, J.; PASCUAL, J.; SOLER, M. P.; ESCRIBÀ, F.; MESQUIDA, M., (1986): "Sistematización de la loza gótico-mudéjar de Paterna/Manises, Actas del II Congresso Internazionale. La Ceramica medievale nel Mediterraneo Occidentale, pp. 183-203, Firenze,

LERMA, J. V.; BADÍA, A.; LÓPEZ, I.; MARIMÓN, J.; MARTíNEZ, R., (1992): La loza gótico-mudéjar en la ciudad de Valencia. Valencia.

MALALANA UREÑA, A., (1994): Informe-Memoria, Escuela 5 bis de Alcalá de Henares (Madrid), Archivo Regional Comunidad de Madrid. Fondo Consejería de Cultura, Sign. 28131/6.

MARTÍN VISO, I., (2000): "Castillos, poder feudal y reorganización espacial en la Transierra Madrileña, Espacio, Tiempo y Forma, Serie III, Ha Medieval, T. I3, pp. I77-2I3, Madrid..

MARTíNEZ CAVIRÓ, B. (1983): La Loza Dorada, Madrid.

-, (1984): Cerámica de Talavera, Madrid.

MÉNDEZ MADARIAGA, A. y RASCÓN MARQUÉS, S., (1989): Los visigodos en Alcalá de Henares, Alcalá de Henares.

MESQUIDA, M., LÓPEZ PERIS, J.E., PRADES, S. \& SMOLKA. R., (200 I): Las ollerías de Paterna. Tecnología y producción. Volumen I. Siglos XII y XIII. Valencia.

OLMO ENCISO, L., (2002): "Arqueología medieval en Guadalajara: un estado de la cuestión", Actas del I Simposio de Arqueología de Guadalajara, pp. 467-500, Madrid.

ORTEGA ORTEGA, J. M. (2002):, Operis terre turolii, Teruel.

PAREJA SERRADA, A., 1916): Brihuega y su partido, Guadalajara.

PASCUAL, J.; MARTí, J. ( 1986): La cerámica verde-manganeso bajomedieval valenciana, Valencia.

PAVÓN MALDONADO, B., (1982): Alcalá de Henares medieval. Arte Islámico y Mudéjar, Madrid-Alcalá de Henares.

(1997): El Salón de Concilios del Palacio Arzobispal. Alcalá de Henares medieval y su recinto amurallado, siglos XIV y XV. Crónica de su última Restauración, Madrid.
POLO LÓPEZ, J., ( 1996): "Cerámicas finas y de importación en Complutum durante el Bajo Imperio", Acta Antiqua Complutensia I. Complutum y las ciudades hispanas en la Antigüedad Tardía. pp. 225-239, Alcalá de Henares.

POLO LÓPEZ, J, y DÍAZ DEL RÍO-ESPAÑOL, P. ( 1992): Informe Intervención solar sito C/Damas clv C/Rico Home (Alcalá de Henares), Archivo Regional Comunidad de Madrid. Fondo Consejería de Cultura, Sign. 28131/1.

PORTILLA y ESQUIVEL, M., Historia de la Ciudad de Compluto, Alcalá de Henares, 1725.

PRESAS, M. M.; SERRANO, E. y TORRA, M., (2009): "Materiales cerámicos estratificados (siglos IX-XVI) en el Reino de Toledo", Actas del VIII Congreso Internacional de Cerámica Medieval en el Mediterráneo, pp. 805-824, Ciudad Real.

RETUERCE VELASCO, M., (1998): La cerámica andalusí de la meseta, Madrid.

-, (2004): "Testimonios materiales del Madrid andalusî". Turina Gómez, A.; Pérez Navarro, A. y Quero Castro, S. (2004) (coord.): Testimonios del Madrid medieval, pp. 8I- | |5, Madrid.

RIERA FRAU, M M; ROSSELLÓ BORDOY, G. y SOBERATS SAGRERAS, N. (1998): "Las tinajas estampilladas de época almohade y la producción de Quesada (Jaén)", Salvatierra Cuenca,V. (1998) (coord.): Hispania, Al-Andalus, Castilla. Jornadas Históricas del Alto Guadalquivir, 8, pp. 239-264, Jaén

ROMÁN GARRIDO, L. (1990): “Intervención Arqueológica en la c/Ramón y Cajal 8 y 10 de Alcalá de Henares (Madrid)", Archivo Regional Comunidad de Madrid. Fondo Consejería de Cultura, Sign. 28I53/4.

-(1993), Memoria Final excavaciones Arqueológicas en la Calle Victoria, 2 (Alcalá de Henares, Madrid) Archivo Regional Comunidad de Madrid. Fondo Consejería de Cultura, Sign. 28150/4.

ROMÁN GARRIDO, L. y DÍAZ-DEL RÍO ESPAÑOL, P. (1996): "Excavación arqueológica en la C/Libreros 36: Notas sobre la denominada cerámica de "repoblación" y algunas apreciaciones sobre la topografía de urbana del Alcalá de Henares medieval", Reunión de Arqueología Madrileña, ,pp. 134-|37, Madrid

ROMÁN PASTOR, C., (1979): Sebastián de la Plaza, alarife de la villa de Alcalá de Henares, Madrid.

-, (1994): Arquitectura conventual de Alcalá de Henares, Alcalá de Henares.

-, (2003): "Parámetros urbanísticos medievales", Alcalá de Henares, páginas de su Historia. XII Curso de Historia, Arte y Cultura, pp. 191-220, Alcalá de Henares

-, (2004): "Alcalá de Henares medieval, aspectos de su geografía urbana", Estudios Geográicos, LXV, 256, pp. 497-539, Madrid

SÁNCHEZ MONTES, A. L., (1996): "El Palacio Arzobispal de Alcalá de Henares. Un estudio arqueológico", Libro-Guía del Visitante del Palacio Arzobispal de Alcalá de Henares. Crónica de su última Restauración. Volumen II. Arte, Arquitectura y Restauraciones, pp. 231-302, Madrid, 
SÁNCHEZ MONTES, A. L. y OLMO ENCISO, L. (1999): "Excavación Arqueológica en la Iglesia Magistral de Alcalá de Henares", en De La Morena. A.; De La Hoz, J. D. y Clemente San Román C., La Catedral Magistral de Alcalá de Henares, pp. 365-397, Alcalá de Henares,

SERRANO, E.; TORRA, M.; CASTRO, M. y SÁNCHEZ, A., (2004): "Excavaciones en Guadalajara: secuencia andalusí desde época emiral a taifa y presentación de un singular conjunto numismático", Arqueología y Territorio Medieval, nII.I, pp. 79-1।3, Jaén.

SERRANO HERRERO, E., TORRA PÉREZ, M. PRESAS VÍAS, M.M. y SÁNCHEZ GONZÁLEZ,A., (2009): Memoria final de la intervención arqueológica realizada en la superficie afectada por el proyecto de construcción de la Biblioteca Central de Humanidades de la Universidad de Alcalá. Convento de San Diego, Archivo Documental Área de Arqueología Universidad de Alcalá.

TORRENS ÁLVAREZ, M.J., (2002): Edición y Estudio Lingüístico del Fuero de Alcalá (Fuero Viejo), Alcalá de Henares.

TORRES BALBÁS, L., (1959): "Complutum, Qal'at 'Abd al-Sal m y Alcalá de Henares", Boletín de la Real Academia de la Historia, CXLIV, pp. I55-I88, Madrid,

TURINA GÓMEZ, A., (1985): "Cerámicas medievales cristianas de Alcalá de Henares (Madrid)", I Congreso de Arqueología Medieval Española, T.V, pp. 649-661, Huesca.
- (1986a): Informe preliminar sobre la excavación realizada en la C/Damas, 4, Archivo Regional Comunidad de Madrid. Fondo Consejería de Cultura, Sign. 28166/5, inédito.

-(1986b): Informe sobre la $1^{a}$ Campaña de Excavación Arqueológica realizada en la Puerta de Burgos de Alcalá de Henares, Archivo Regional Comunidad de Madrid. Fondo Consejería de Cultura, Sign. 28166/14.

-, (1987): "Cerámicas pintadas de Alcalá la Vieja (Alcalá de Henares, Madrid)", II Congreso de Arqueología Medieval Española, T. III, pp. 753-762, Madrid.

-, (200I):"Nuevos datos sobre la cerámica mudéjar en el centro peninsular", V Congreso de Arqueología Medieval Española,T. II, pp. 80 I-822, Valladolid.

TURINA GÓMEZ, A.; PÉREZ NAVARRO, A. y QUERO CASTRO, S. (2004) (coord.): Testimonios del Madrid medieval, 2, Madrid.

VILLANUEVA, O., ( 1998): "Actividad alfarera en el Valladolid bajomedieval", Studia Archaeologica, n 89, Valladolid,

XIMÉNEZ DE RADA, R., Historia de rebus Hispaniae sive Historia Gothica, Turnhout, 1987.

ZOZAYA STABEL-HANSEN, J," "Excavaciones arqueológicas en Qal'at'Abd al-Salām (Alcalá de Henares, Madrid)", Noticiario Arqueológico Hispánico, 17, Madrid, 1983, pp. 4|3-529. 


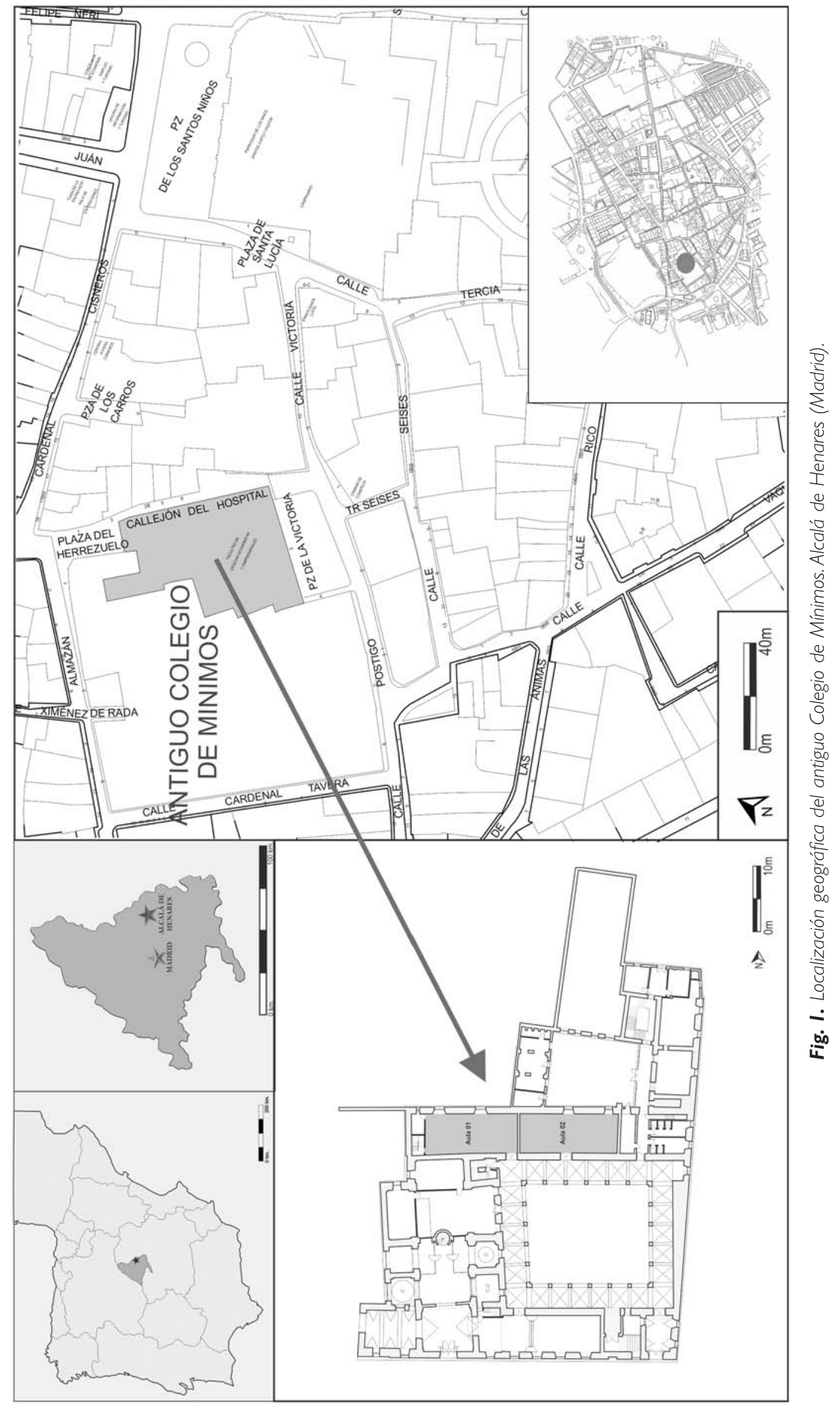



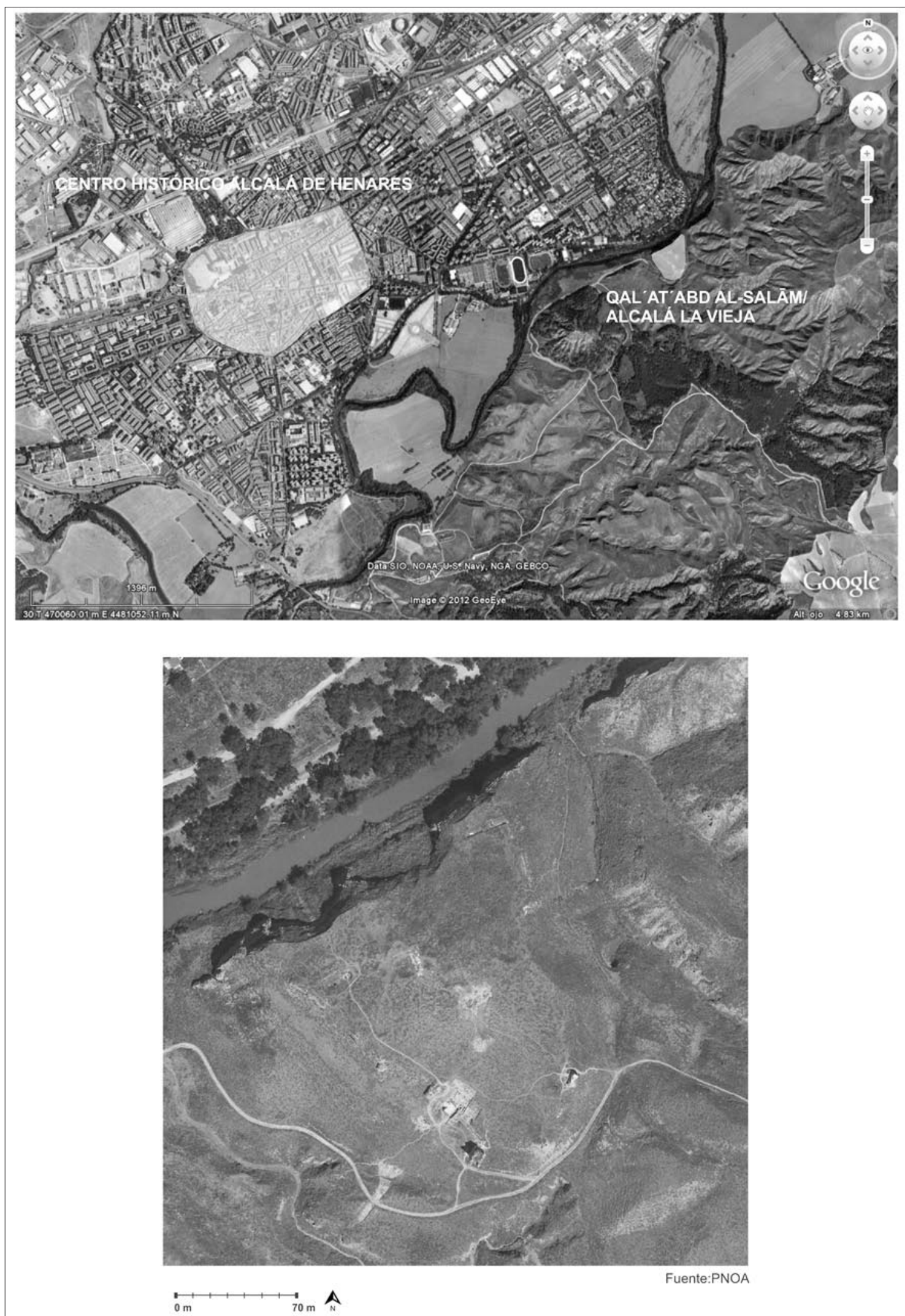

Fig. 2. Contexto territorial Centro Histórico Alcalá de Henares-Fortaleza Alcalá "la Vieja". 


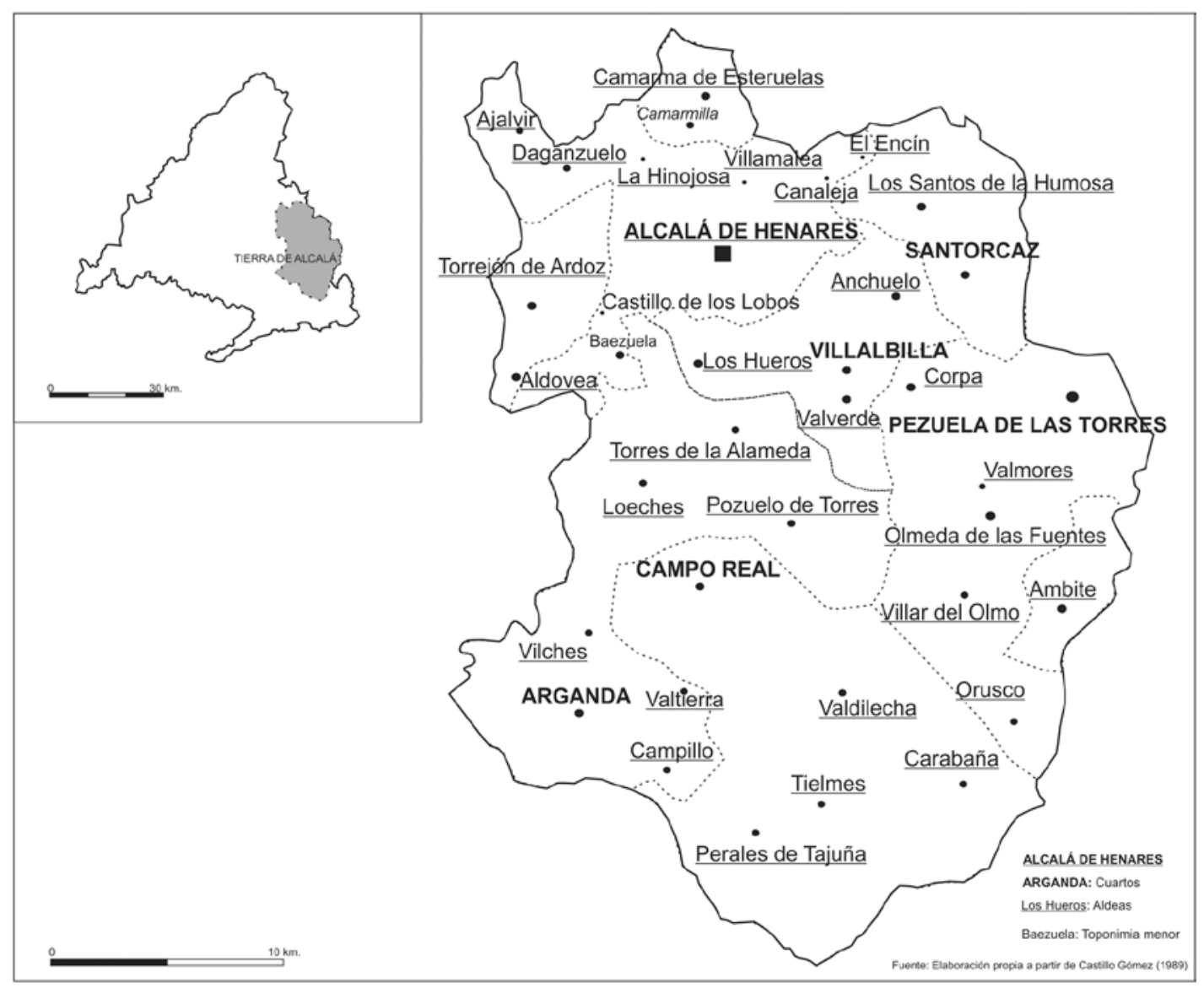

Fig. 3. El territorio de Alcalá de Henares en el siglo XV.

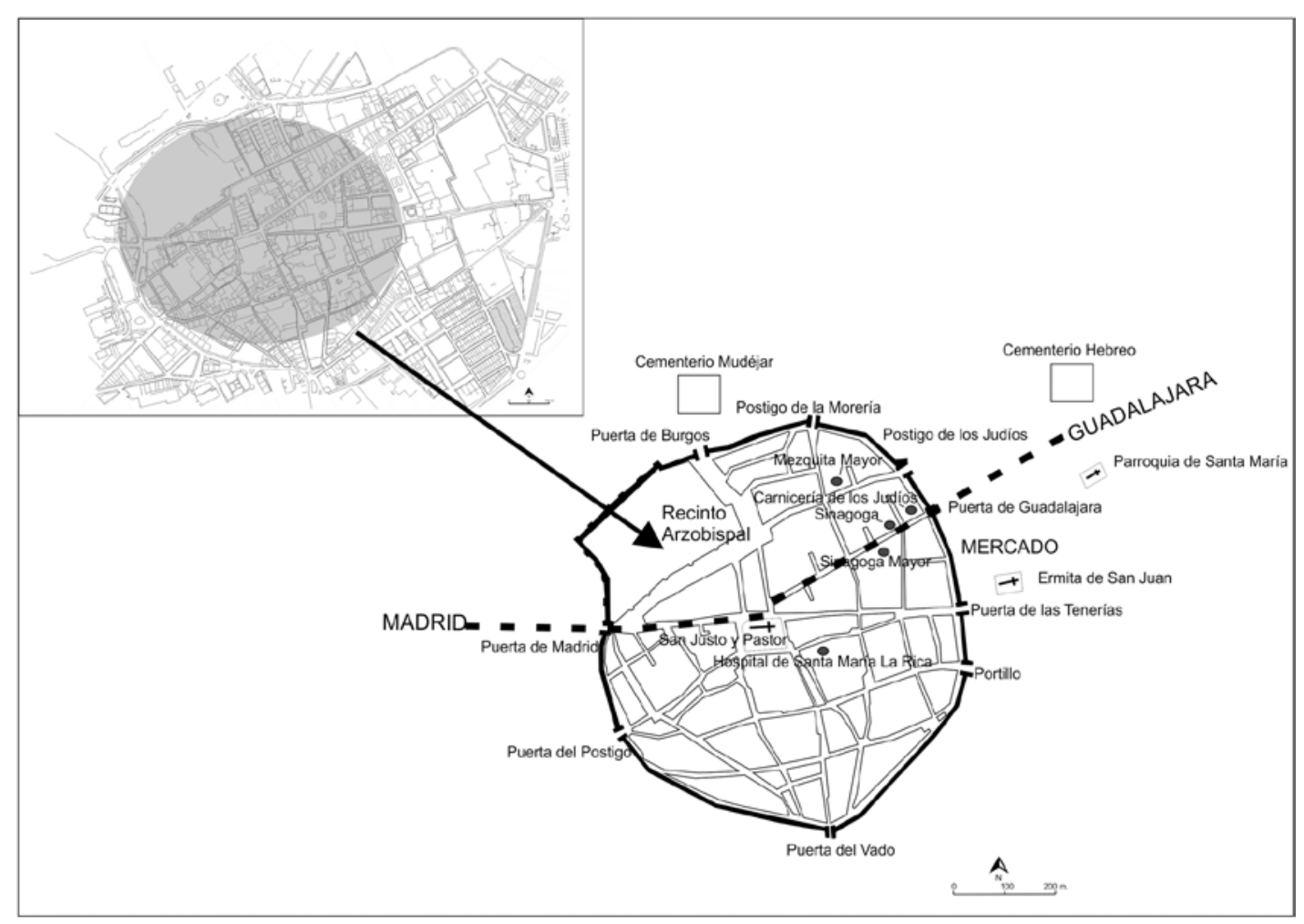

Fig. 4. Evolución urbana Alcalá de Henares s. XIII-XIV (Román Pastor, 1993). 


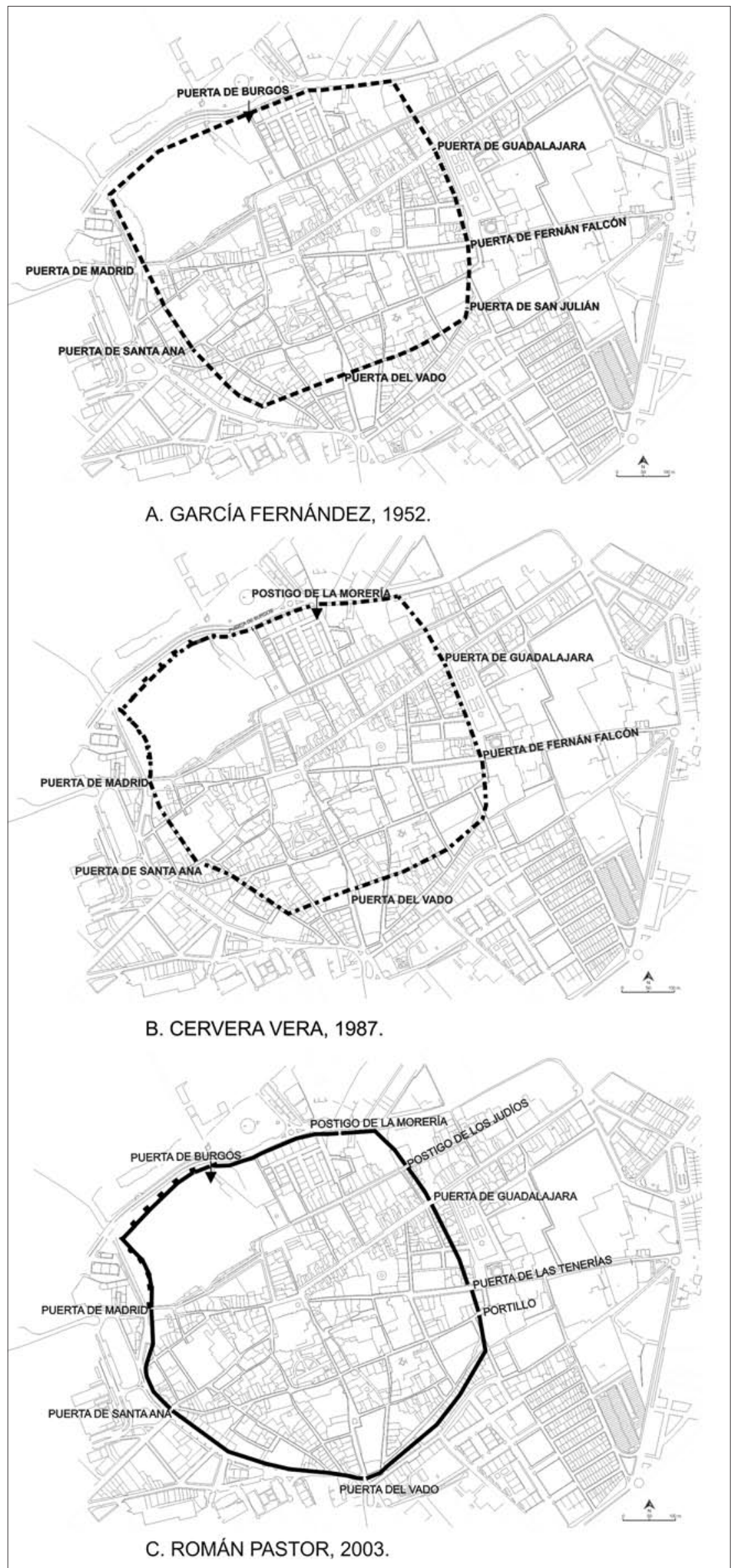

Fig. 5. Trazados hipotéticos cerca siglo XIII. 

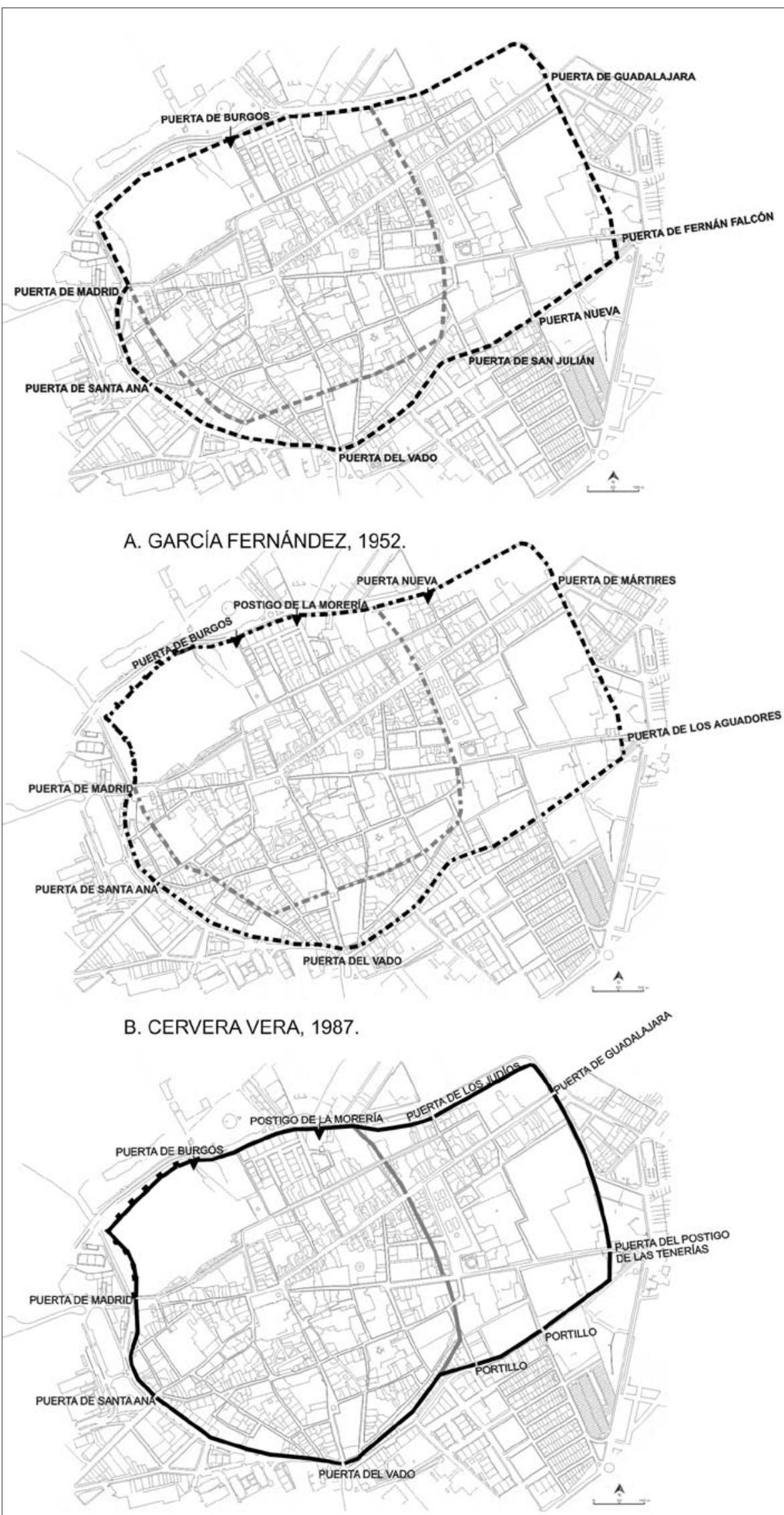

C. ROMÁN PASTOR, 2003.

Fig. 6. Trazados hipotéticos cerca siglo XV. 

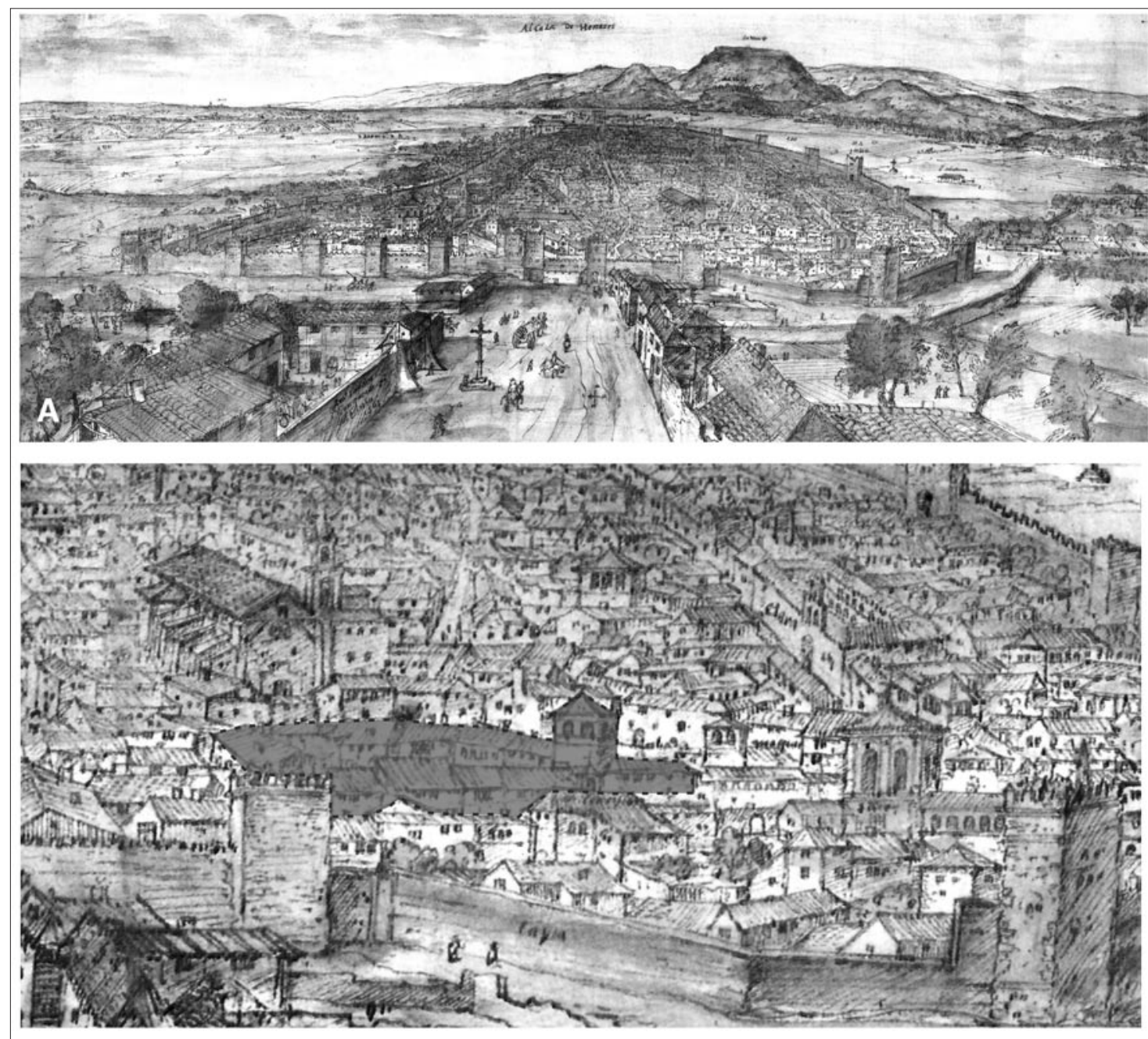

Fig. 7. A: Grabado de Alcalá de Henares obra de Anton van den Wyngaerde (h. 1565). B: Caserío previo a la construcción del Colegio de Mínimos de Santa Ana.

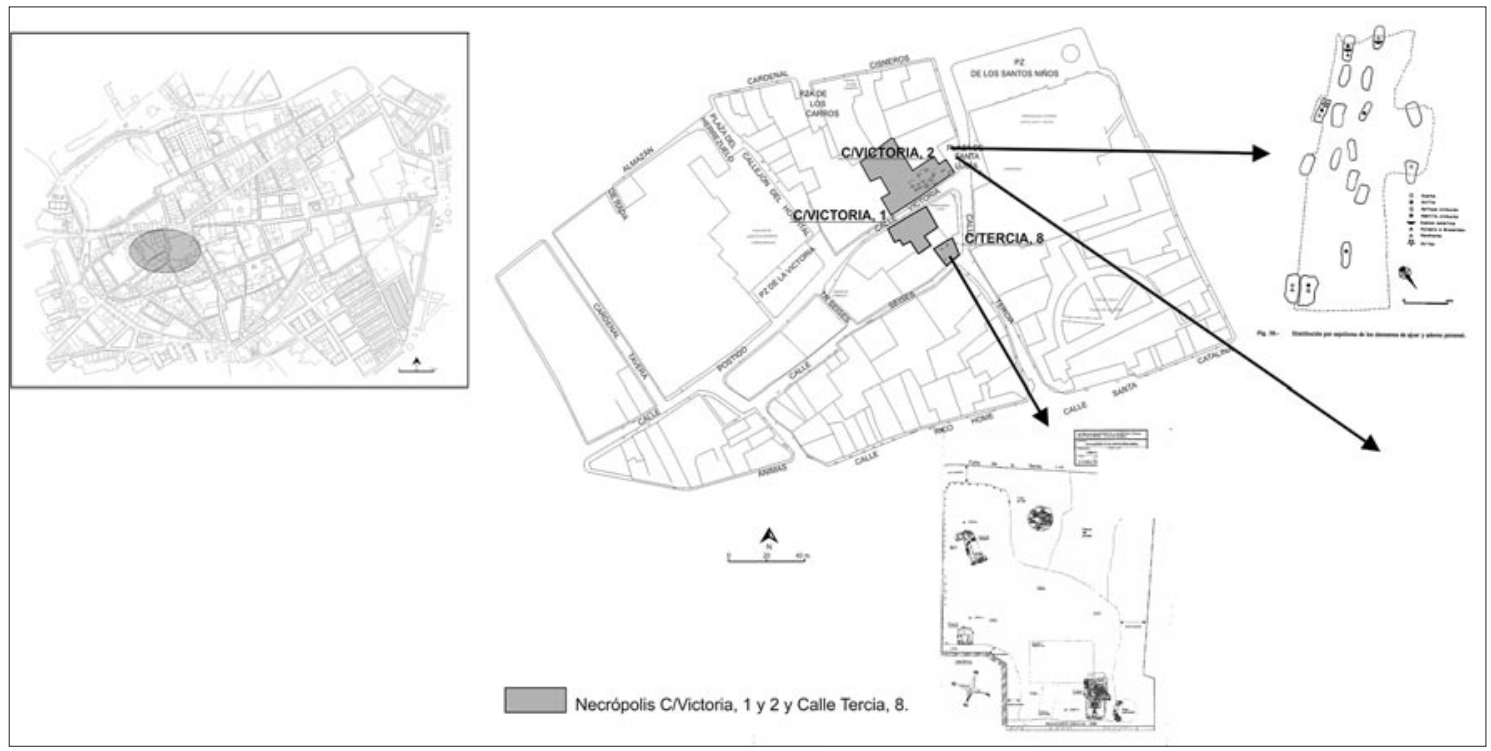

Fig. 8. Necrópolis c/Victoria, I y 2, c/Tercia, 8. Fuente: Memoria Excavación Arqueológica c/Victoria, 2, Román Garrido (1993) y Memoria Excavación Arqueológica c/Tercia, 8, Polo López y Toledo Mozos (1999). 

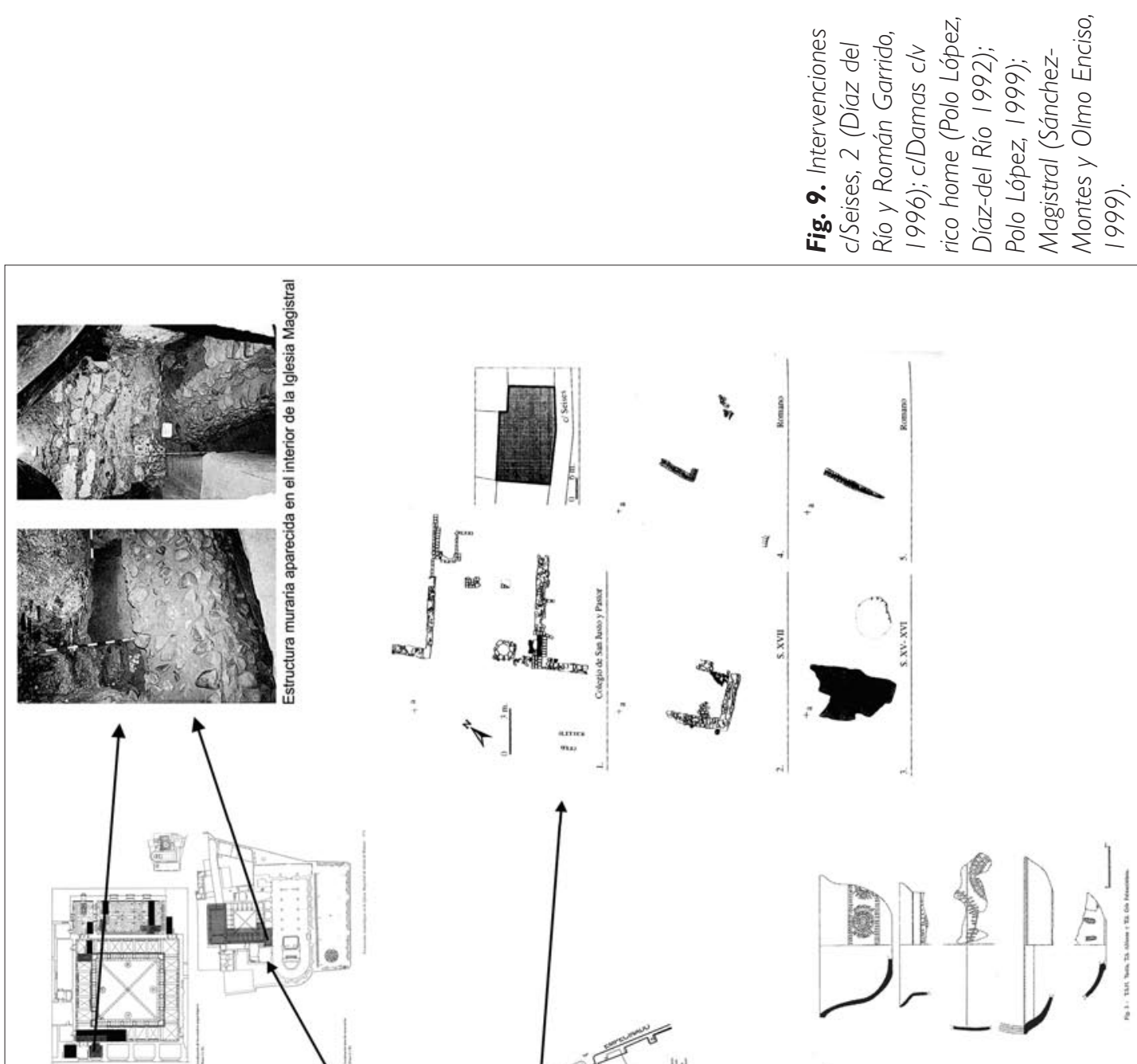

$\uparrow$
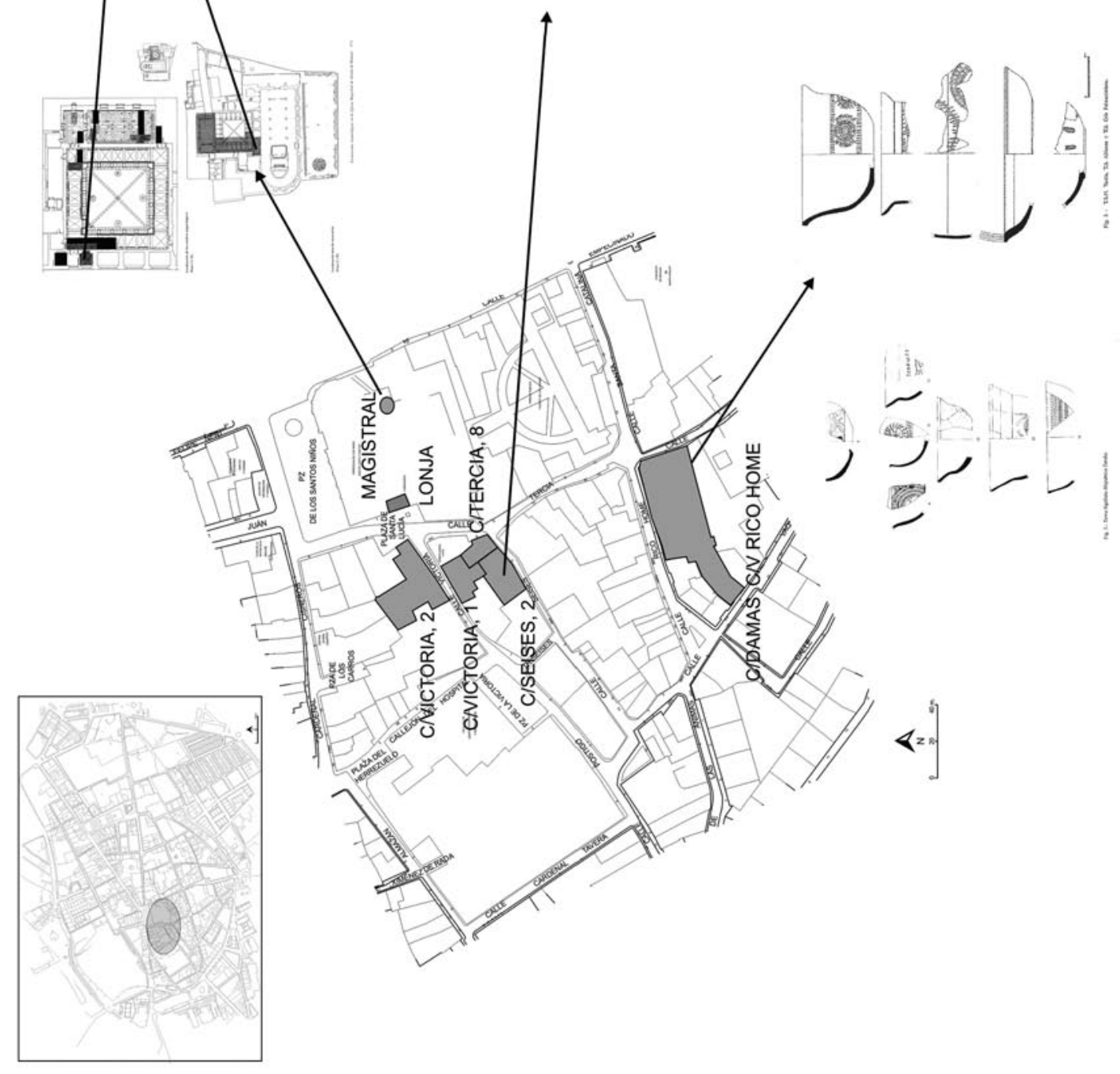


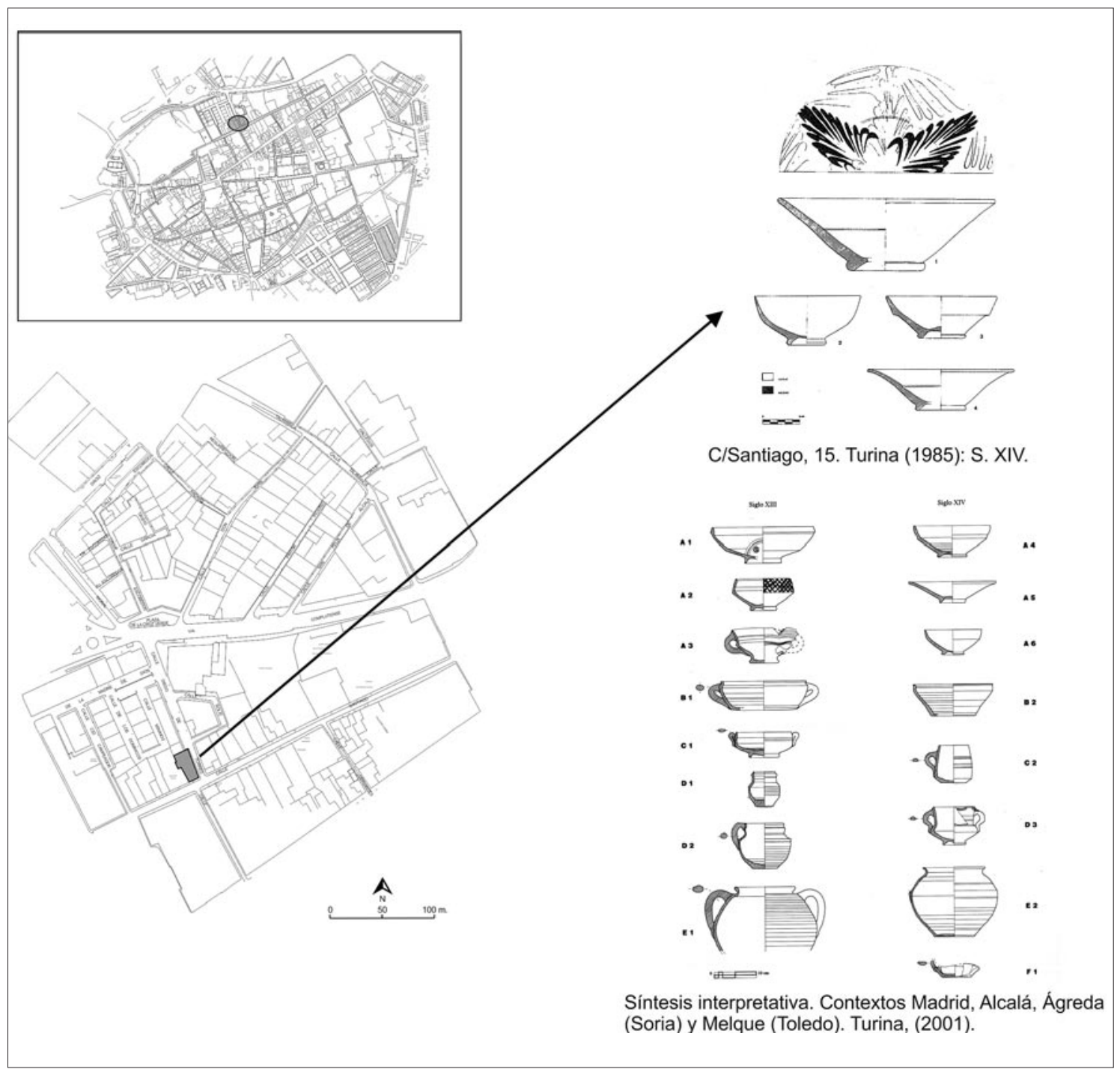

Fig. 10. Definición cronotipológica de la cultura cerámica bajomedieval. C/Santiago, 15. 


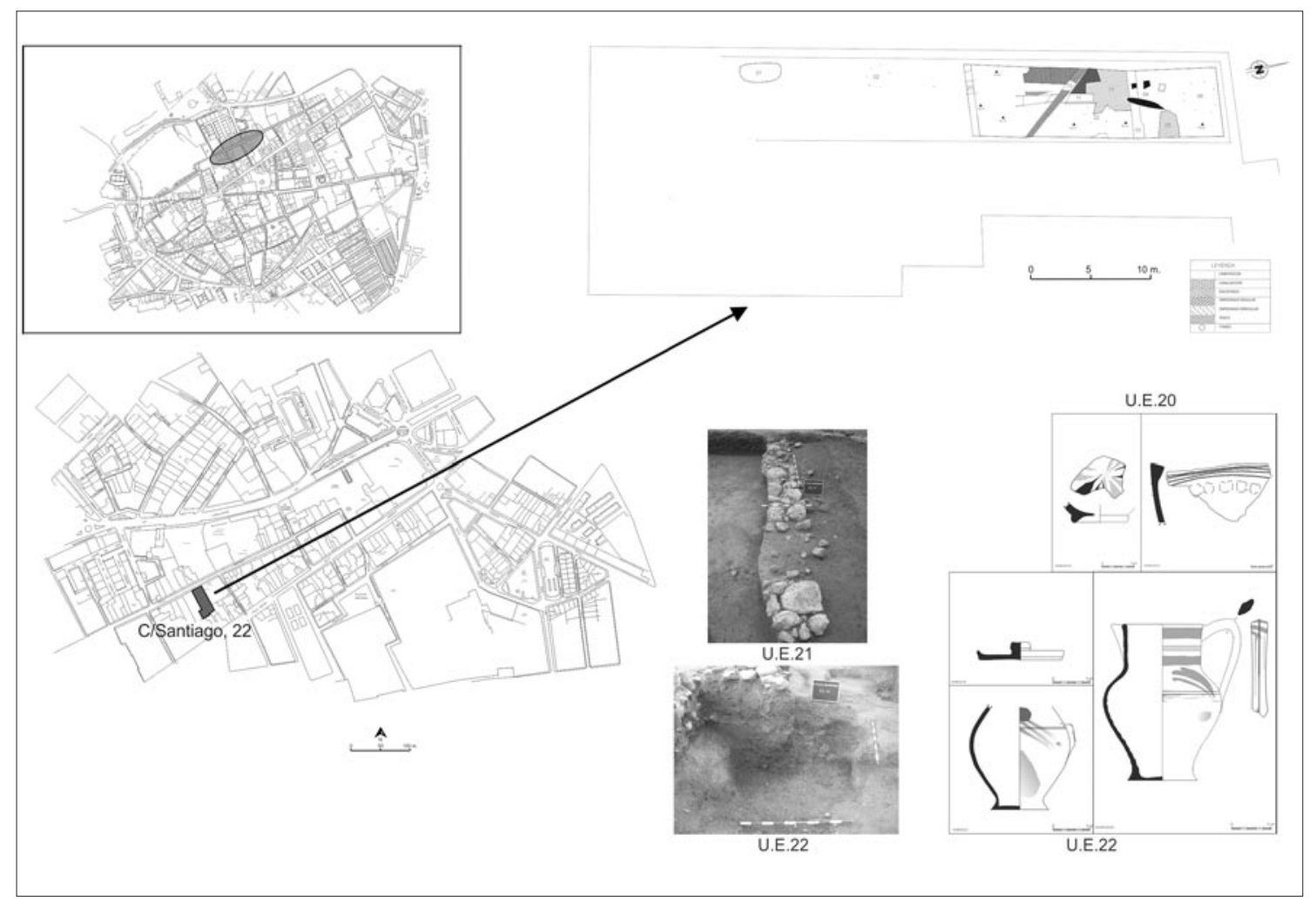

Fig. II. Intervención c/Santiago, 22. Arias Cabezudo (2005). Principales contextos y series tipológicas.

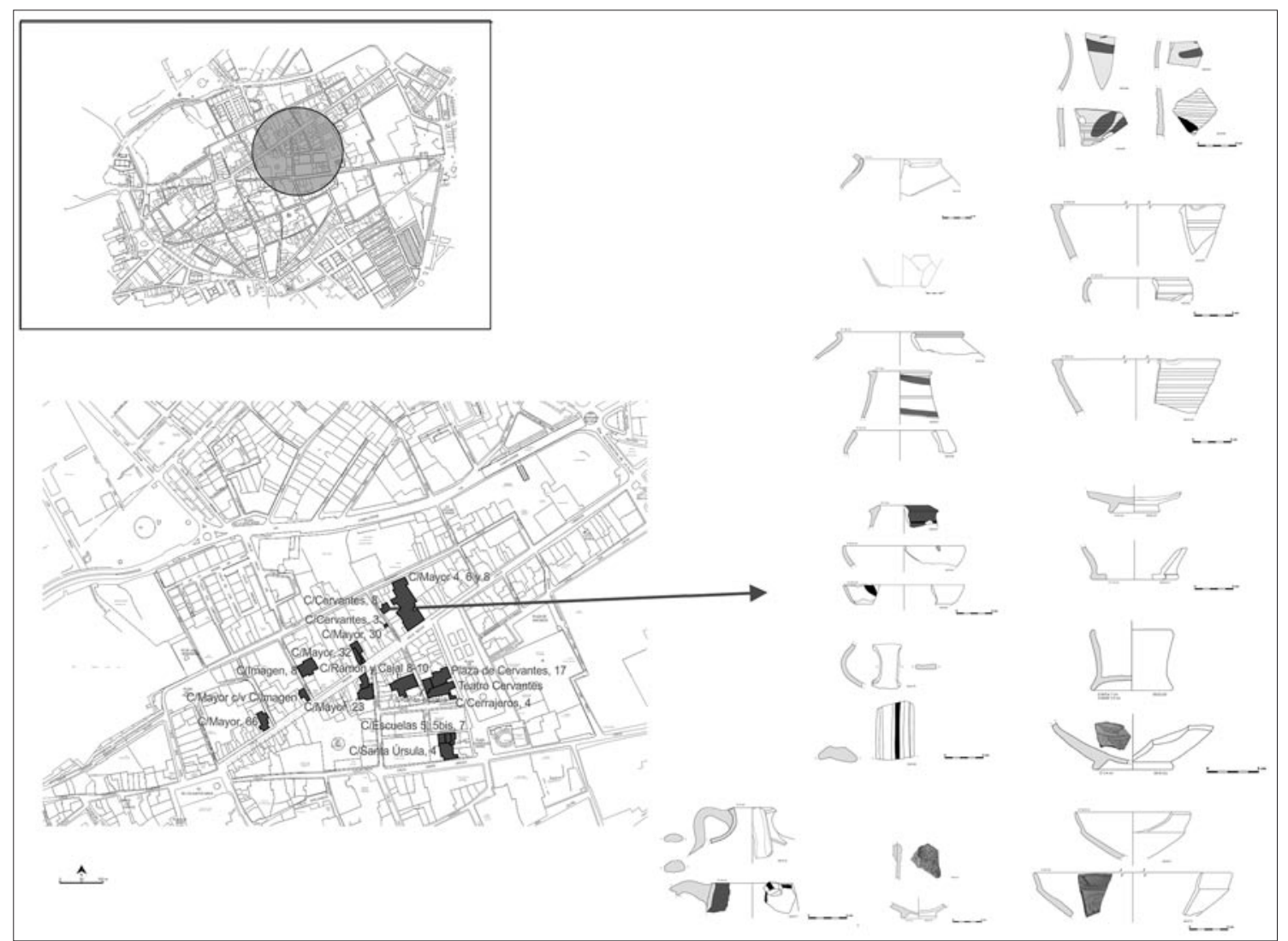

Fig. I2. Intervenciones sector c/Mayor-c/Santa Úrsula. Materiales de la U.E. 5 C/Cervantes, 8 (Aldecoa, 2008). 

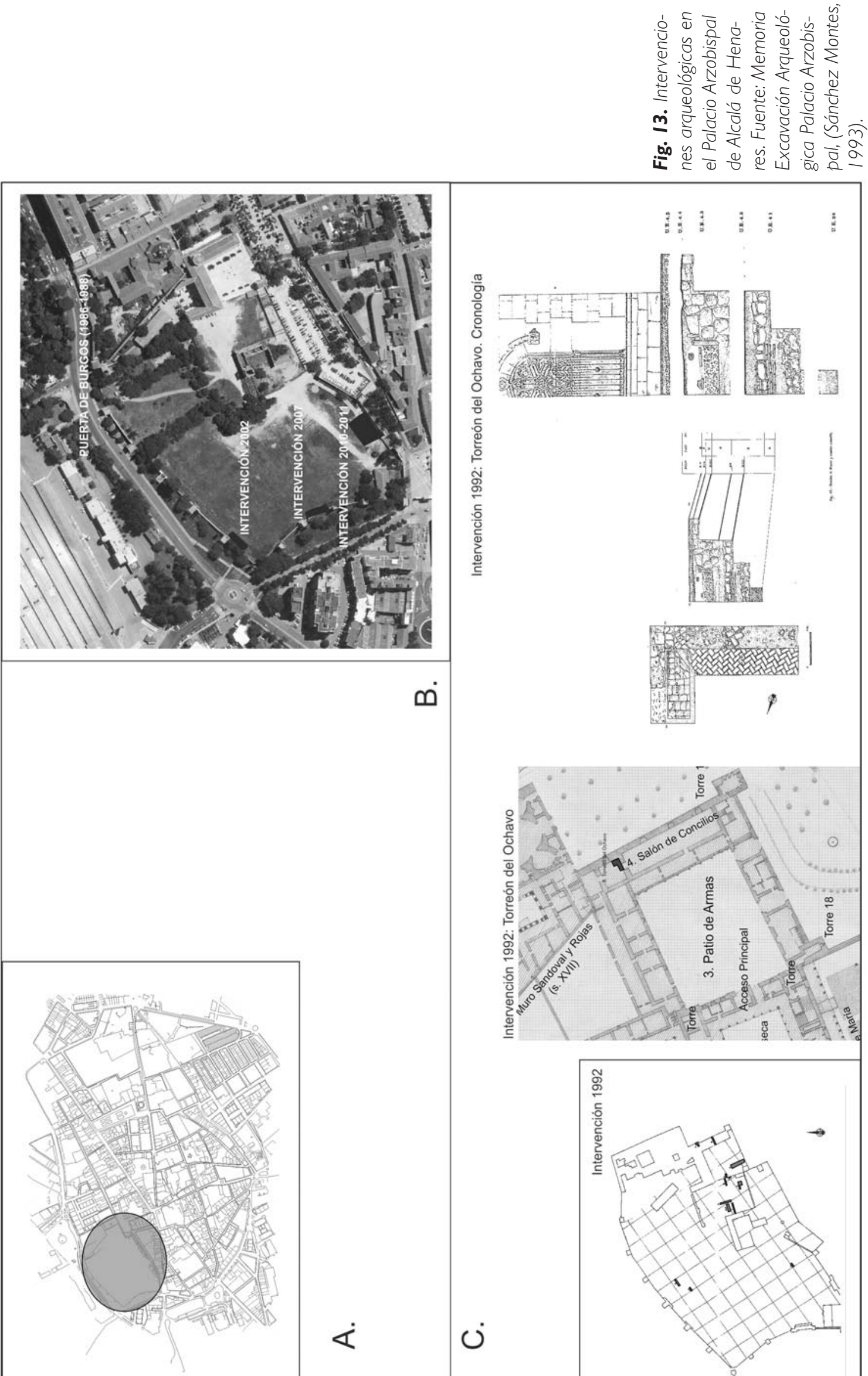

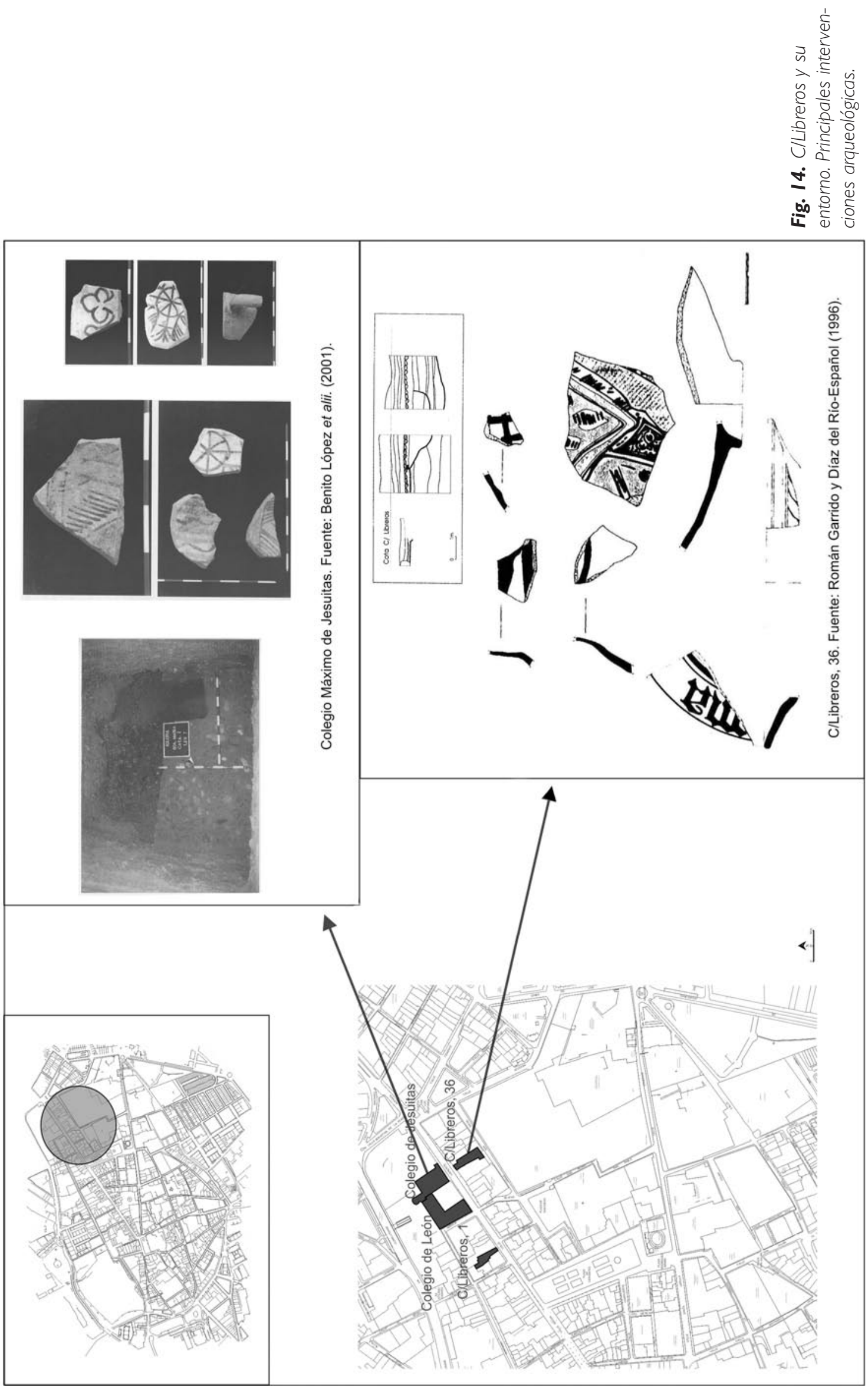


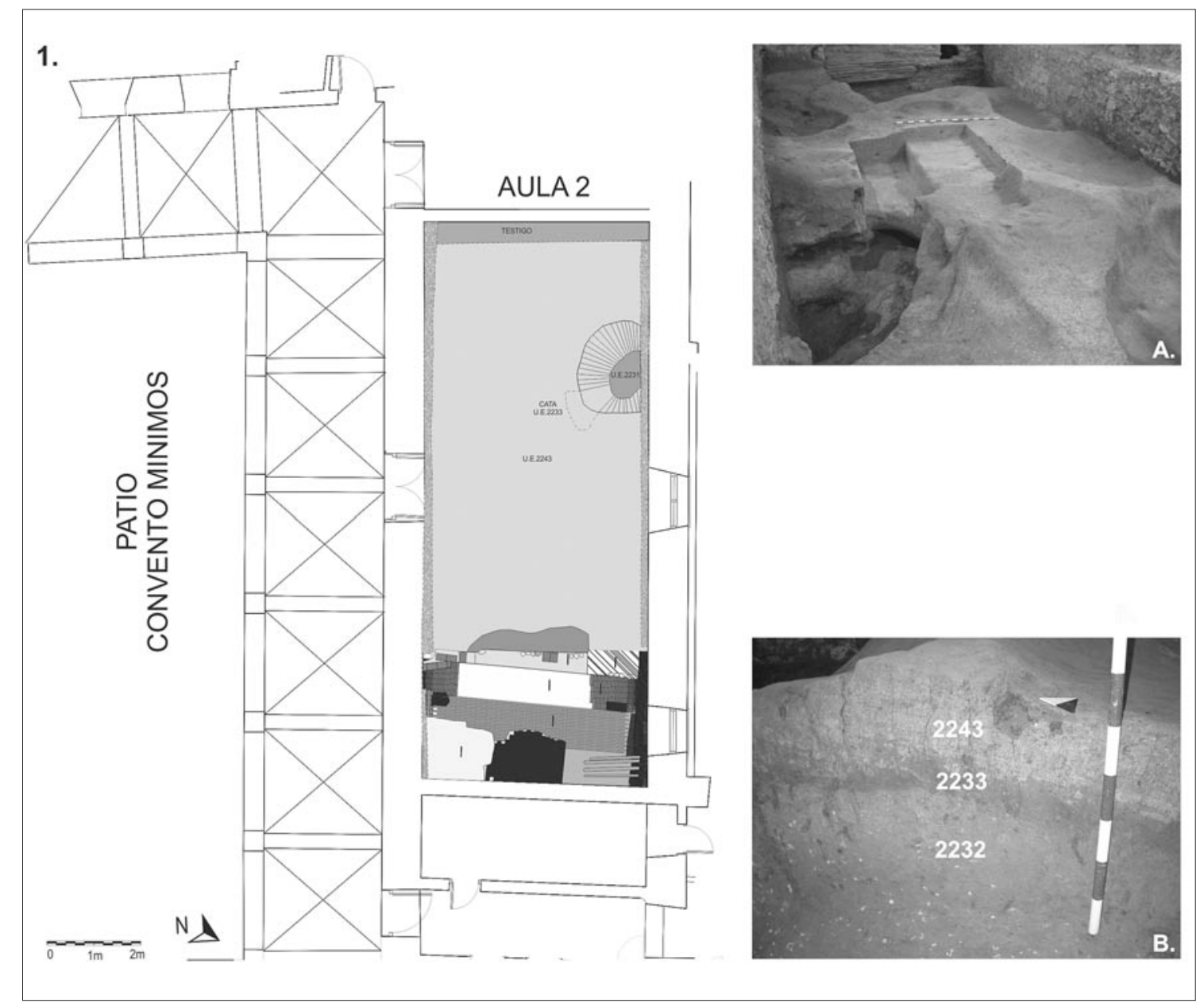

Fig. I5. (Contextos anteriores finales siglo XIII) A: U.E. 2243 (Fase II). B: Detalle U.E. 2243 (Fase II), 2233, 2232 (fase I). 


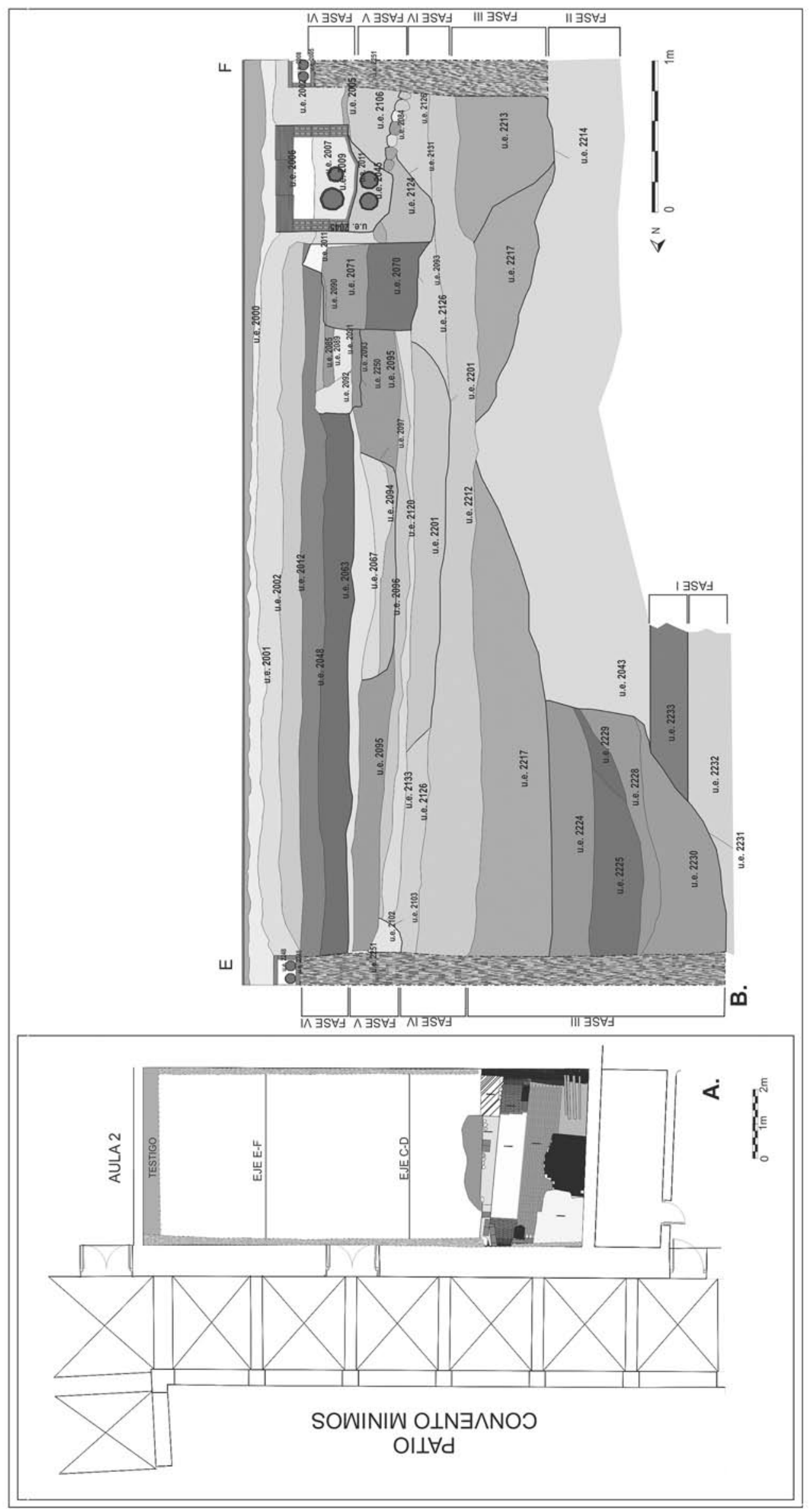

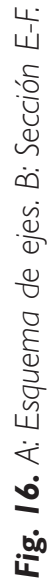




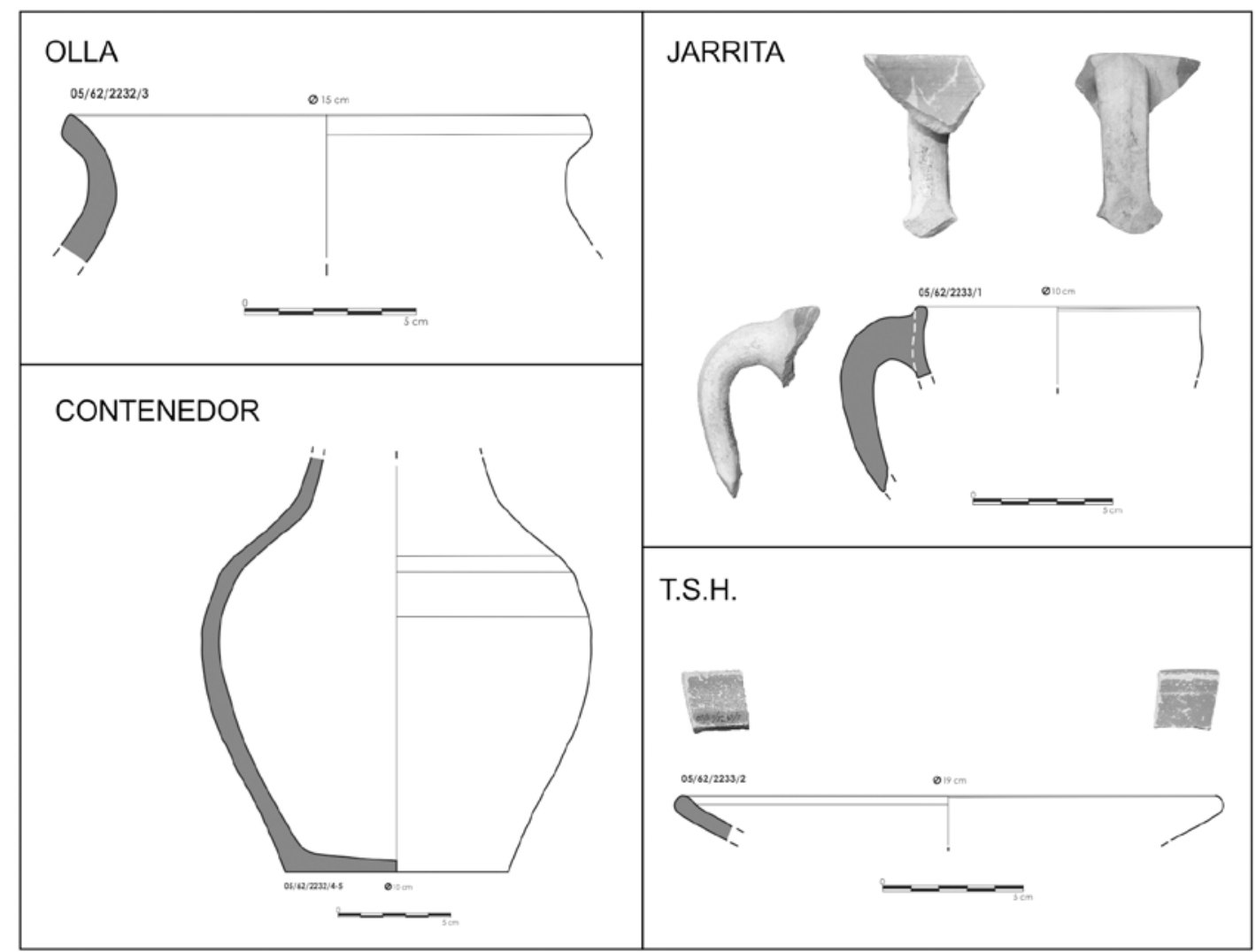

Fig. I 7. Fase I: UU.EE. 2233 Y 2232.

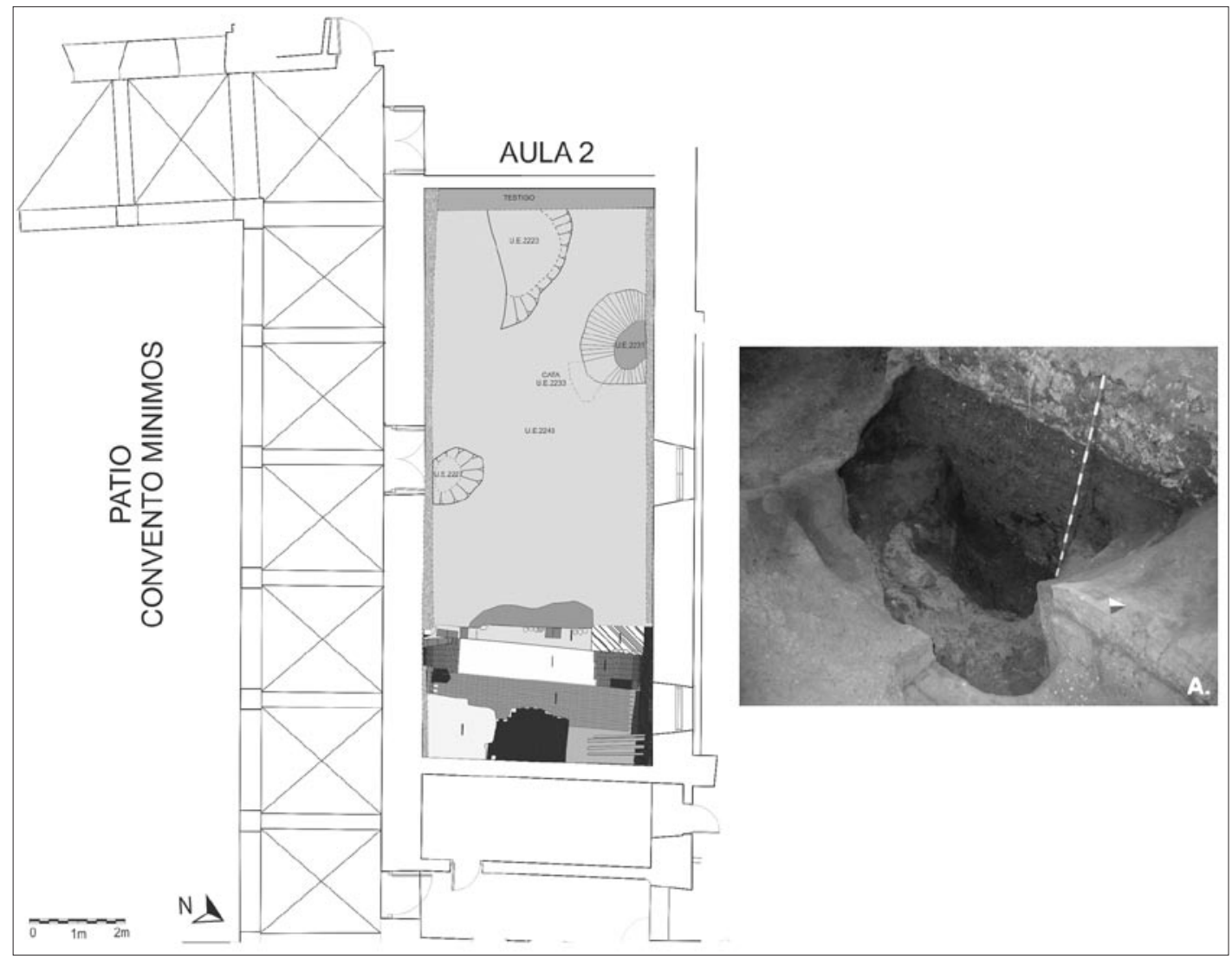

Fig. I8. (Fase III-III) a. U.E.N. 2231 (Fase III). 


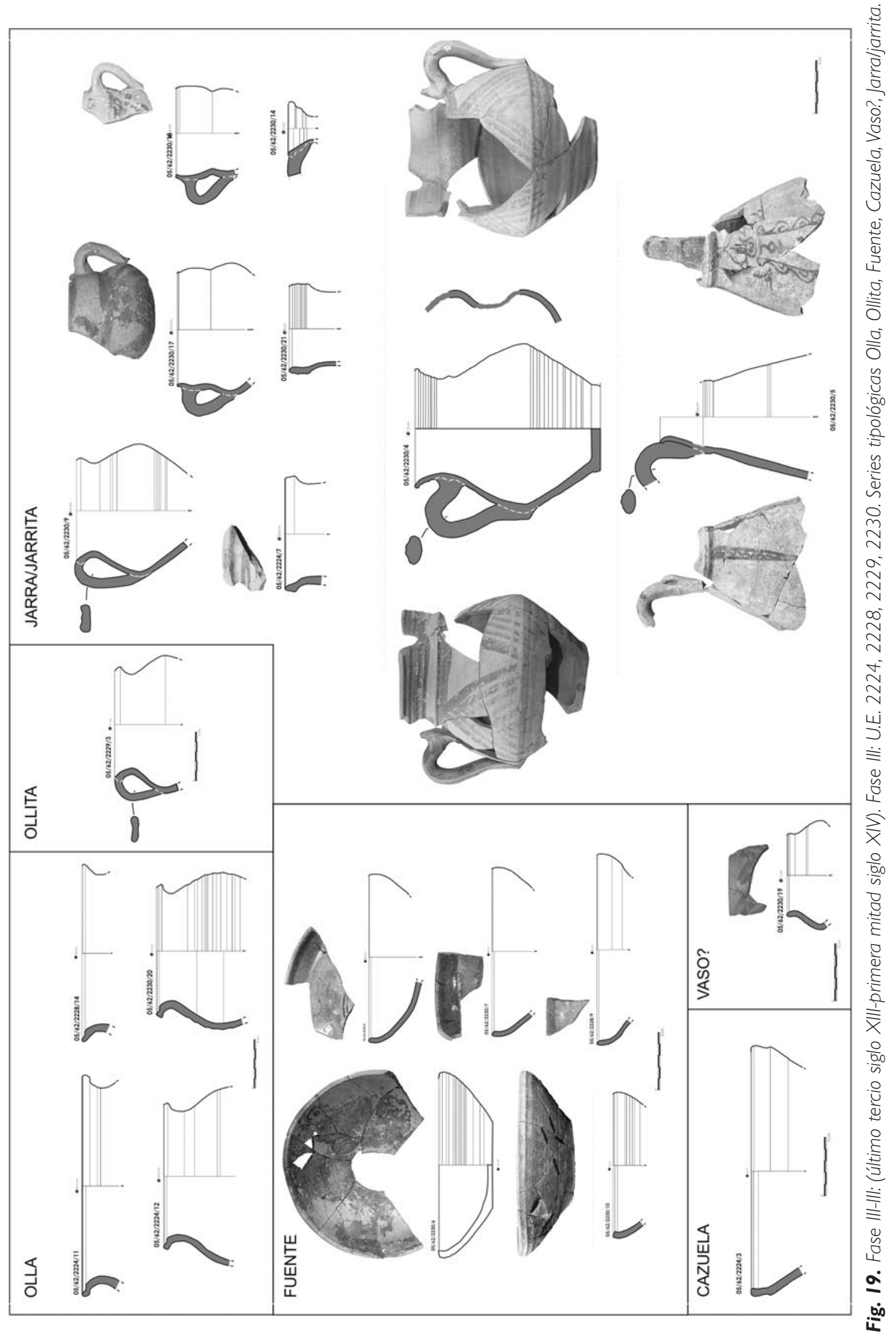



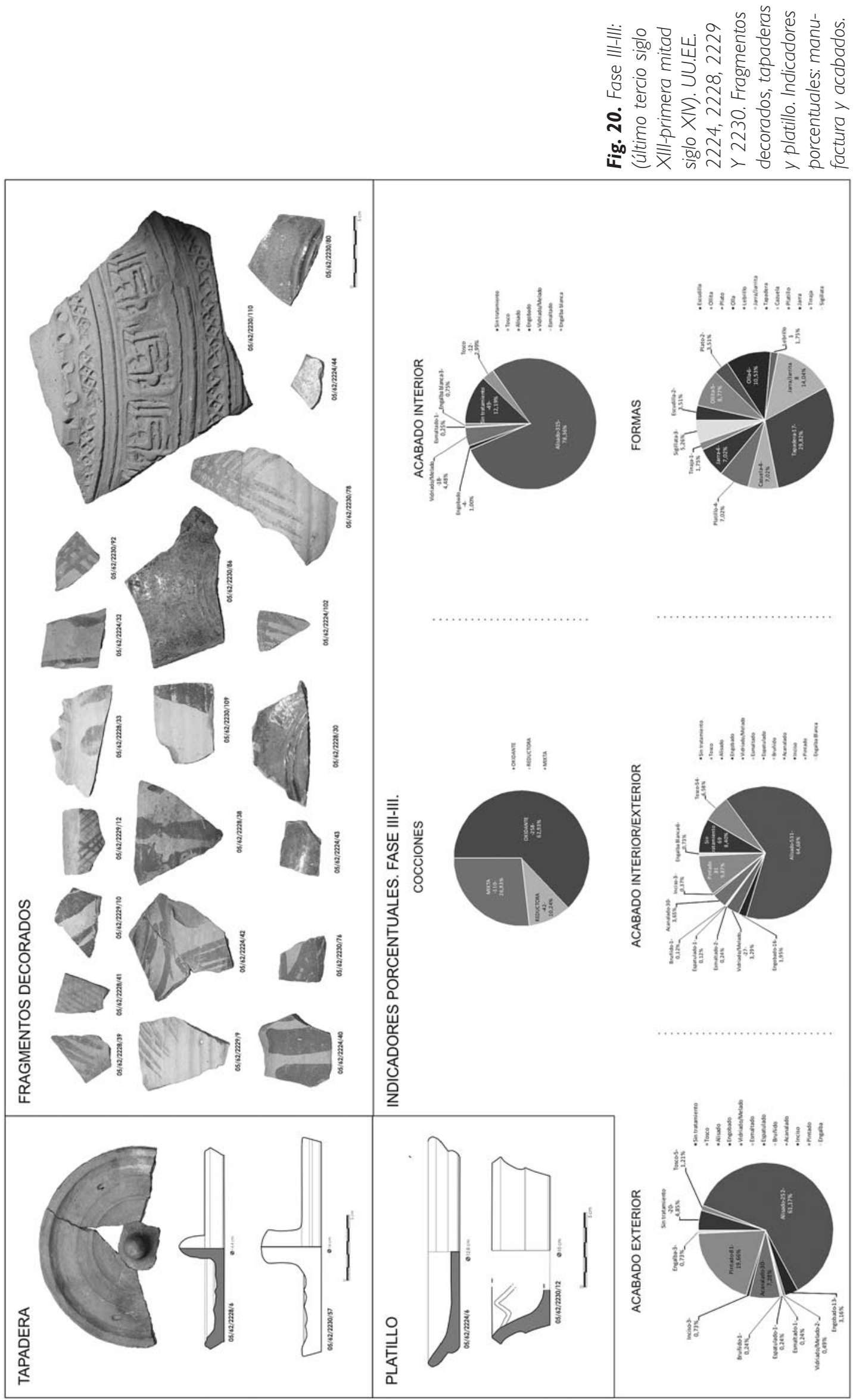


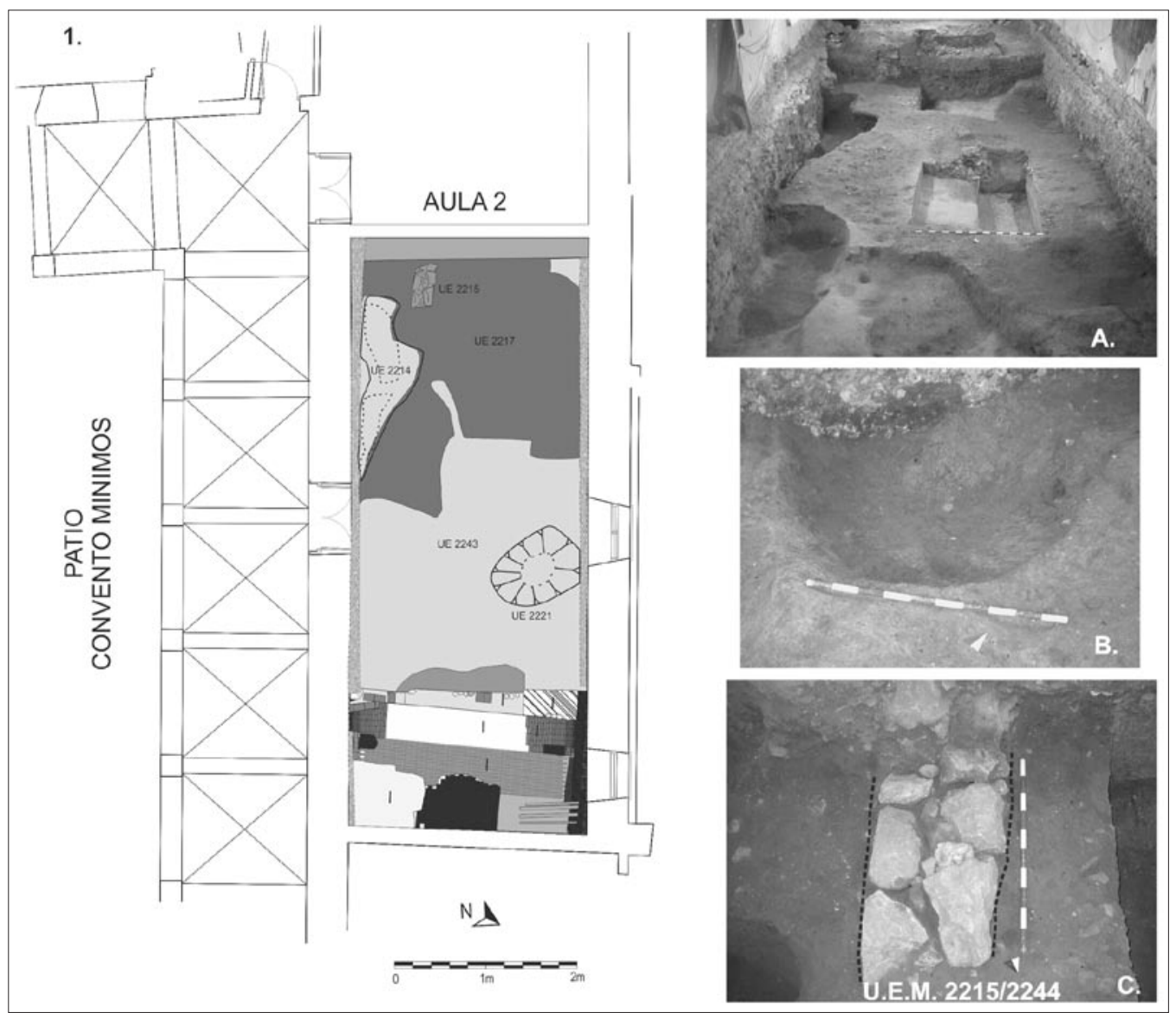

Fig. 2 I. (Segunda mitad del siglo xiv inicios del s. XV) A: U.E. 2217 (Fase III-II: $2^{a}$ mitad s. XIV). B: U.E.N. 2221 (Fase IV-III: inicios s. XV). C: U.E.M. 2215 (Fase III-I: último tercio s. XIV-inicios del XV).

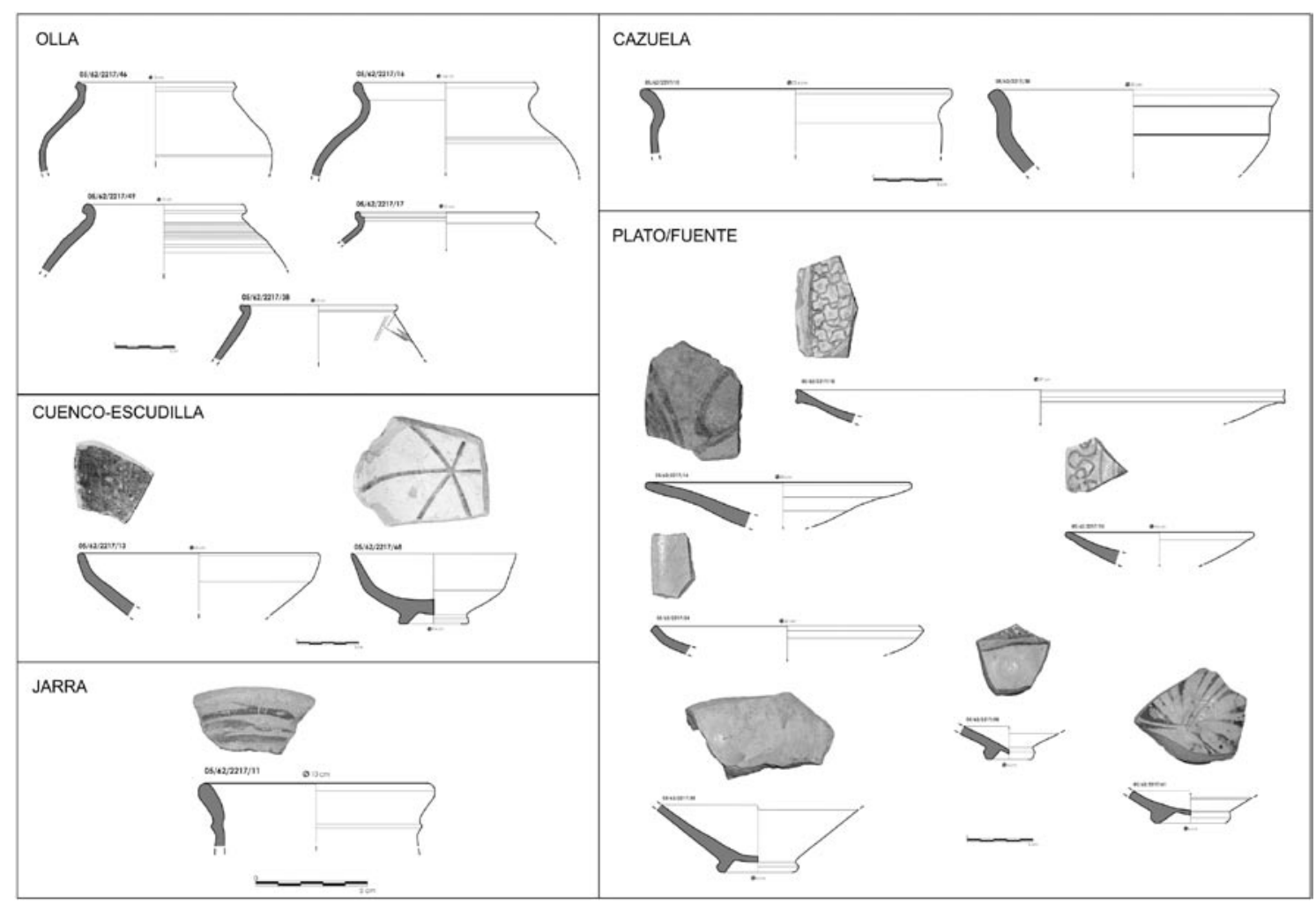

Fig. 22. Fase III-II: (2ª mitad siglo XIV). U.E. 22 I 7. Series tipológicas Olla, Cazuela, Cuenco-escudilla, Jarra y Plato/Fuente. 


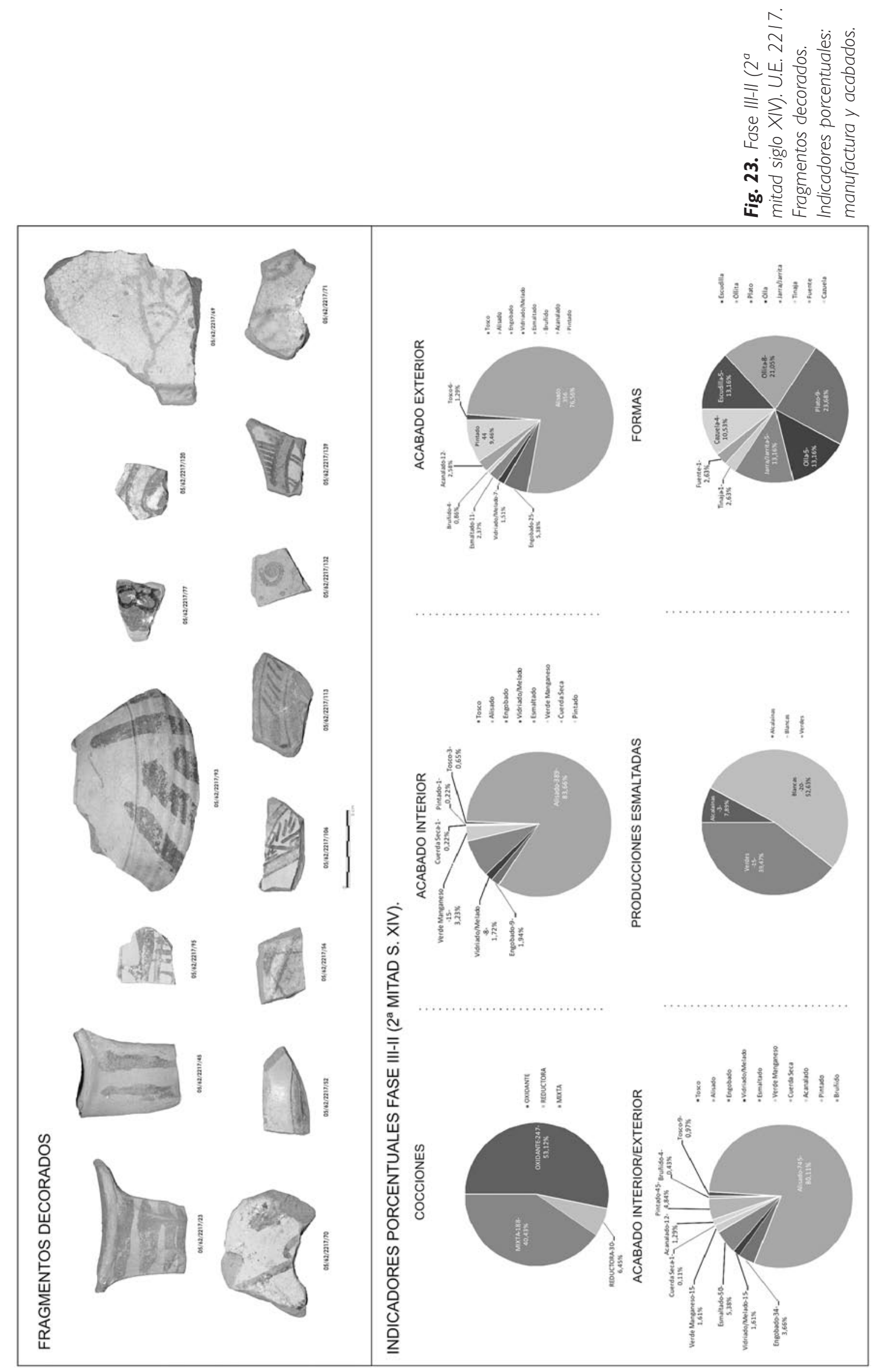



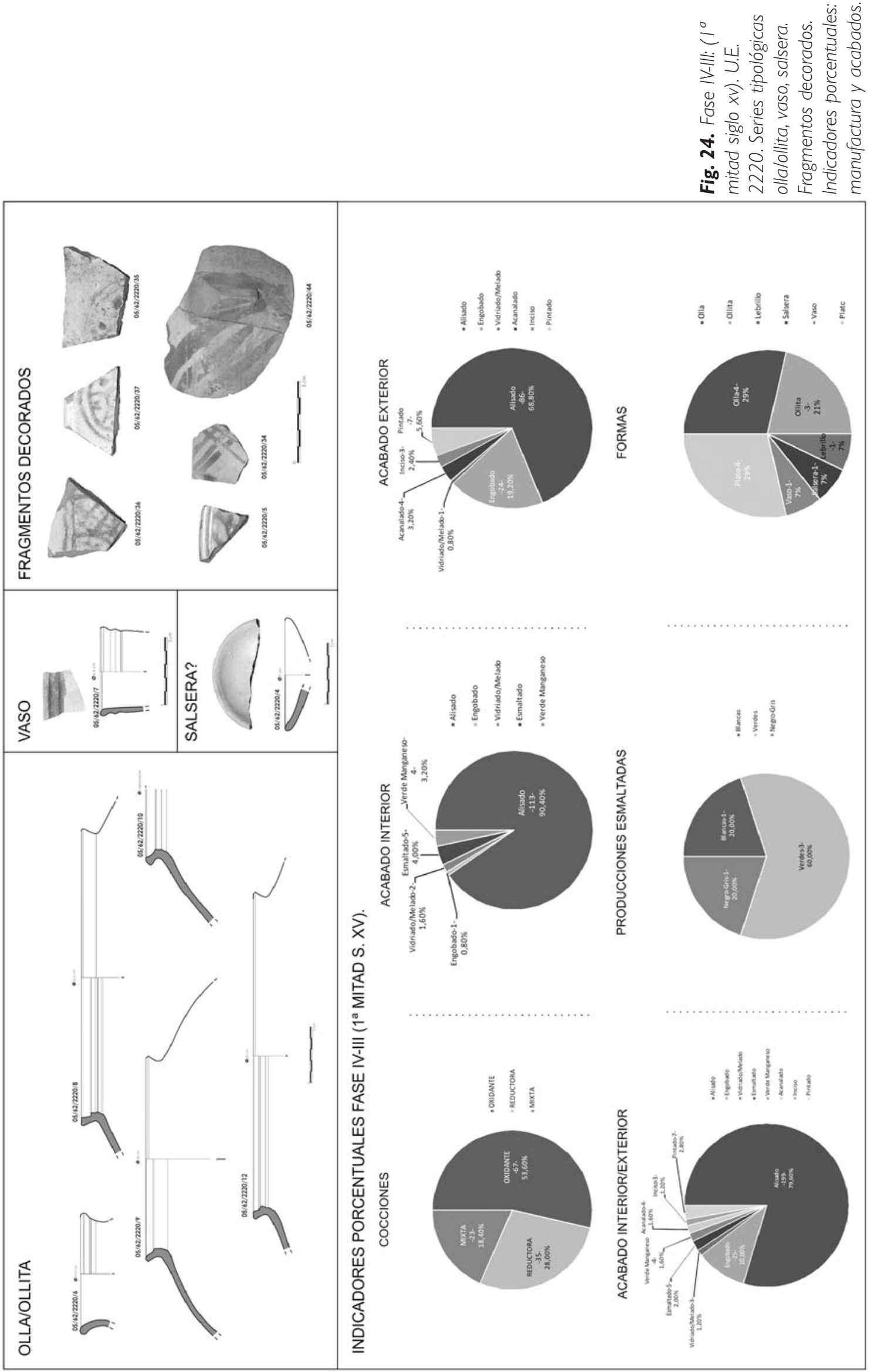

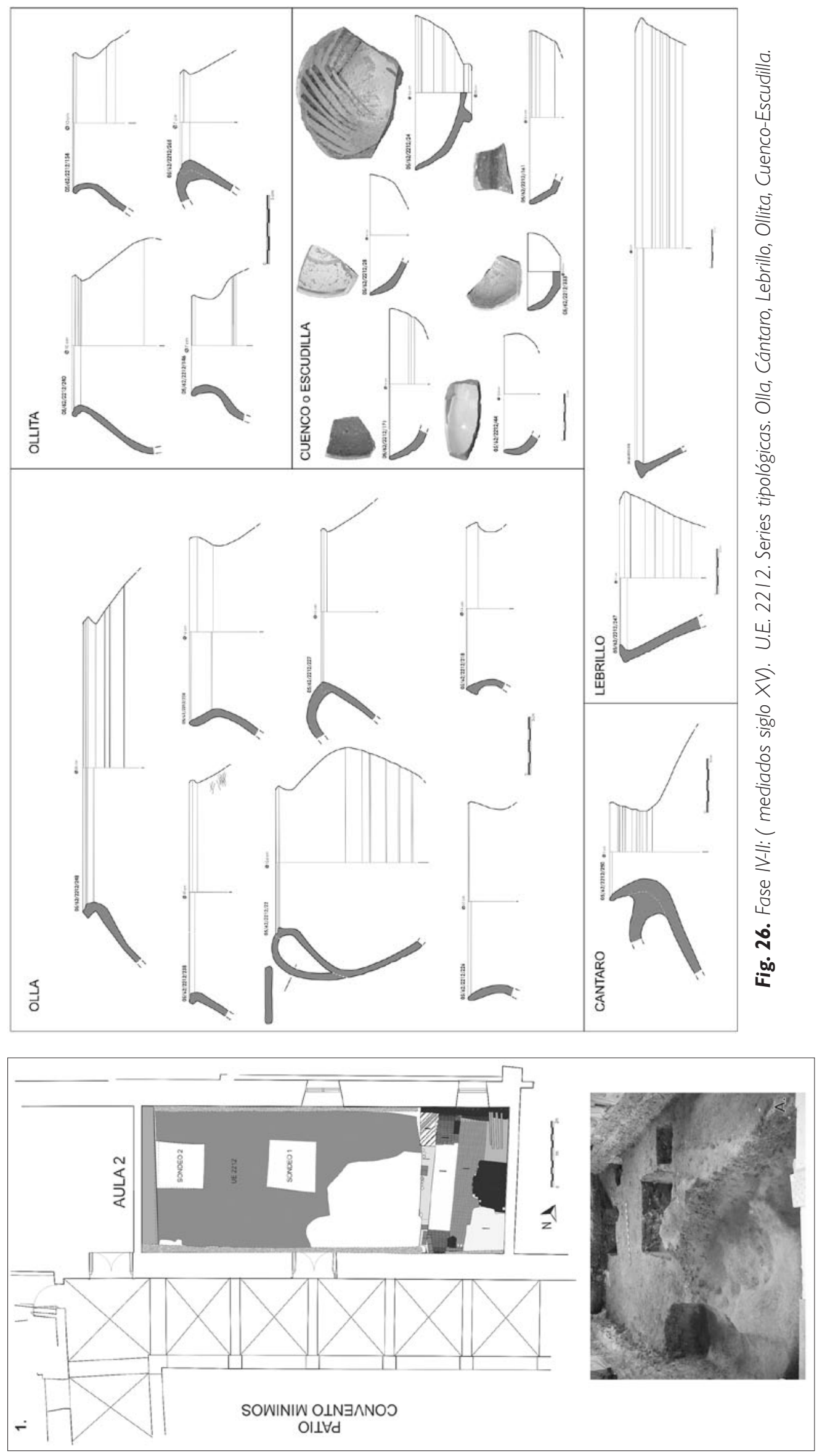

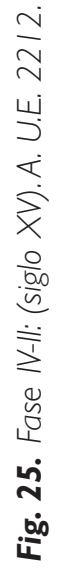




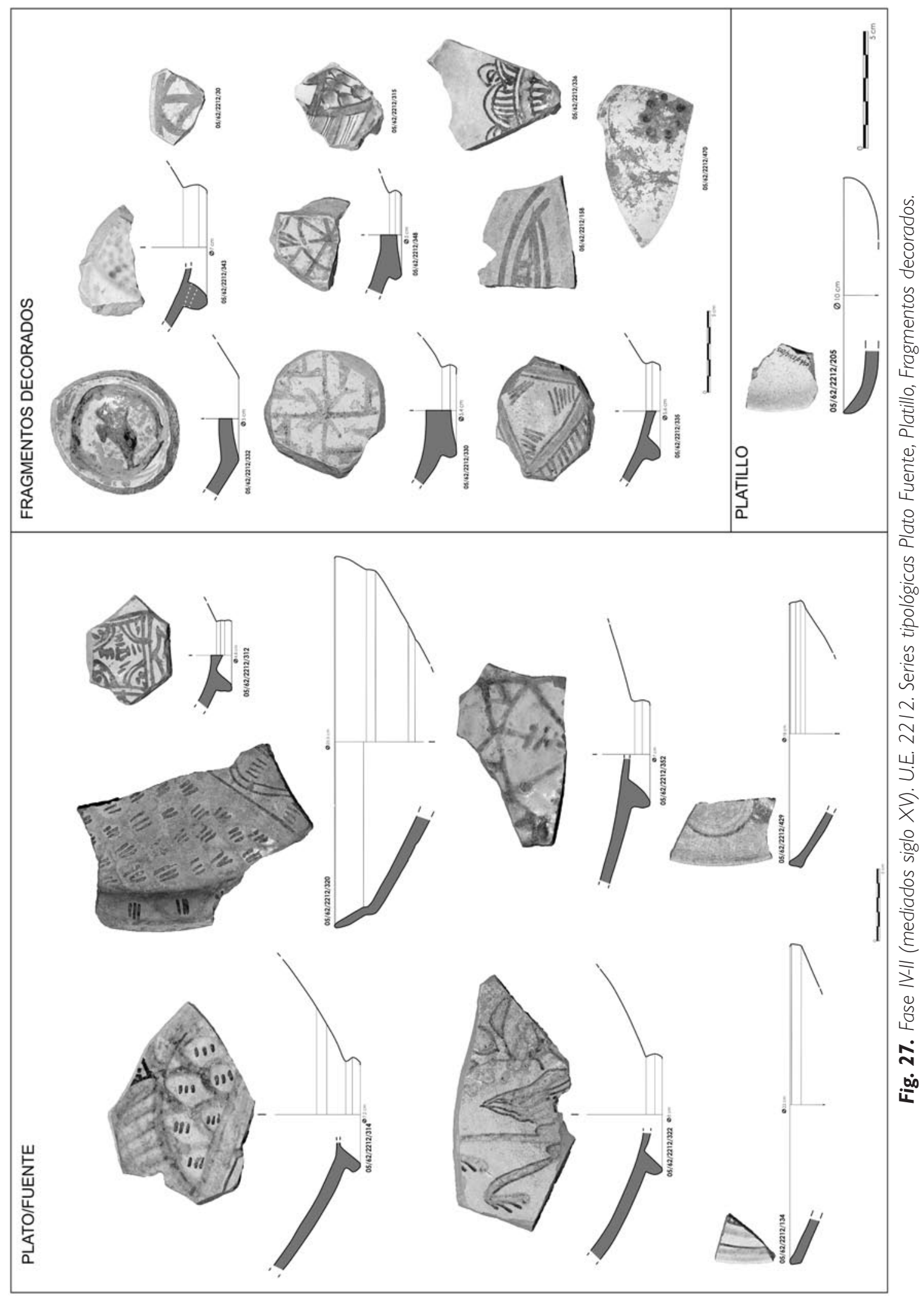



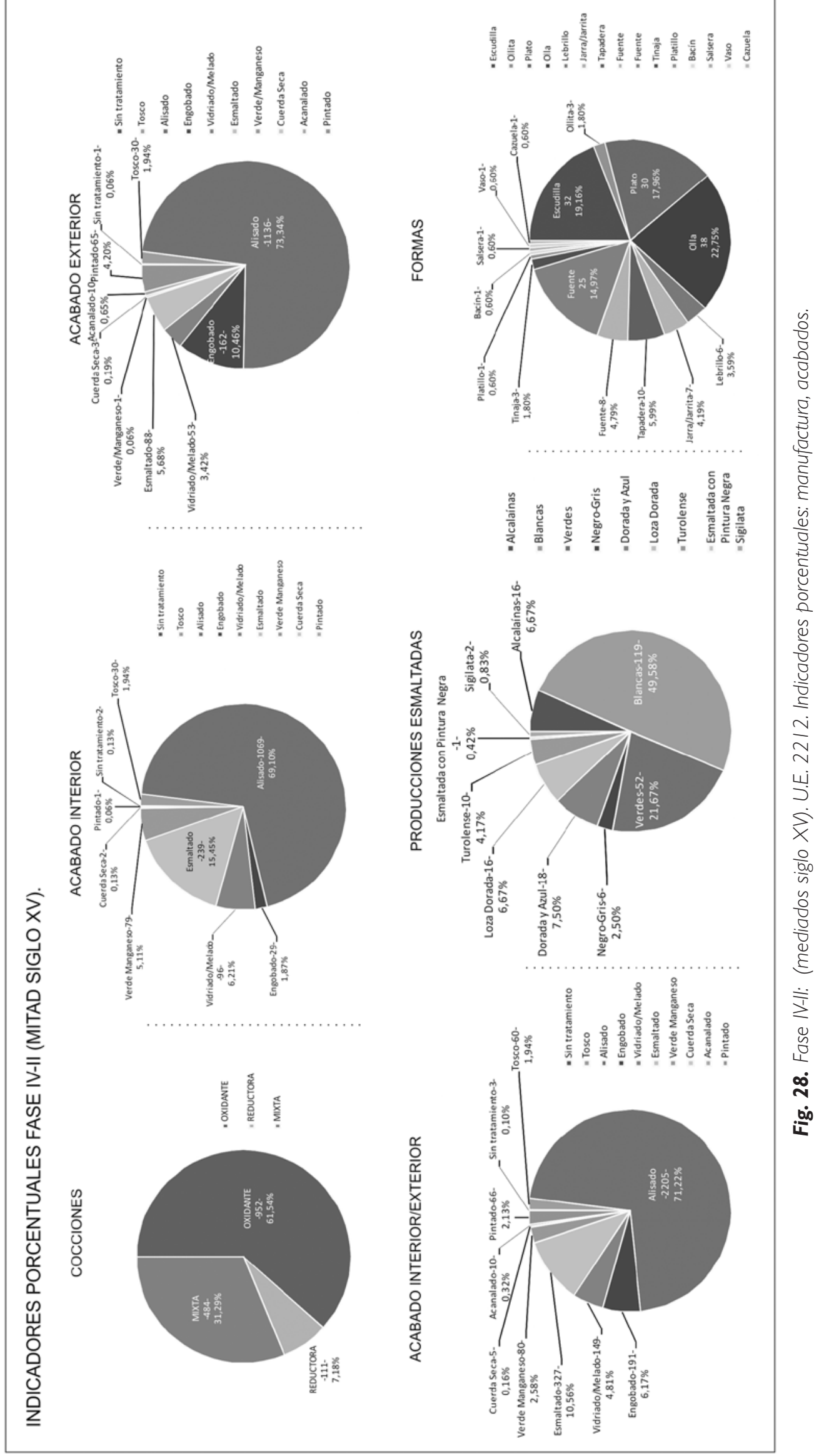


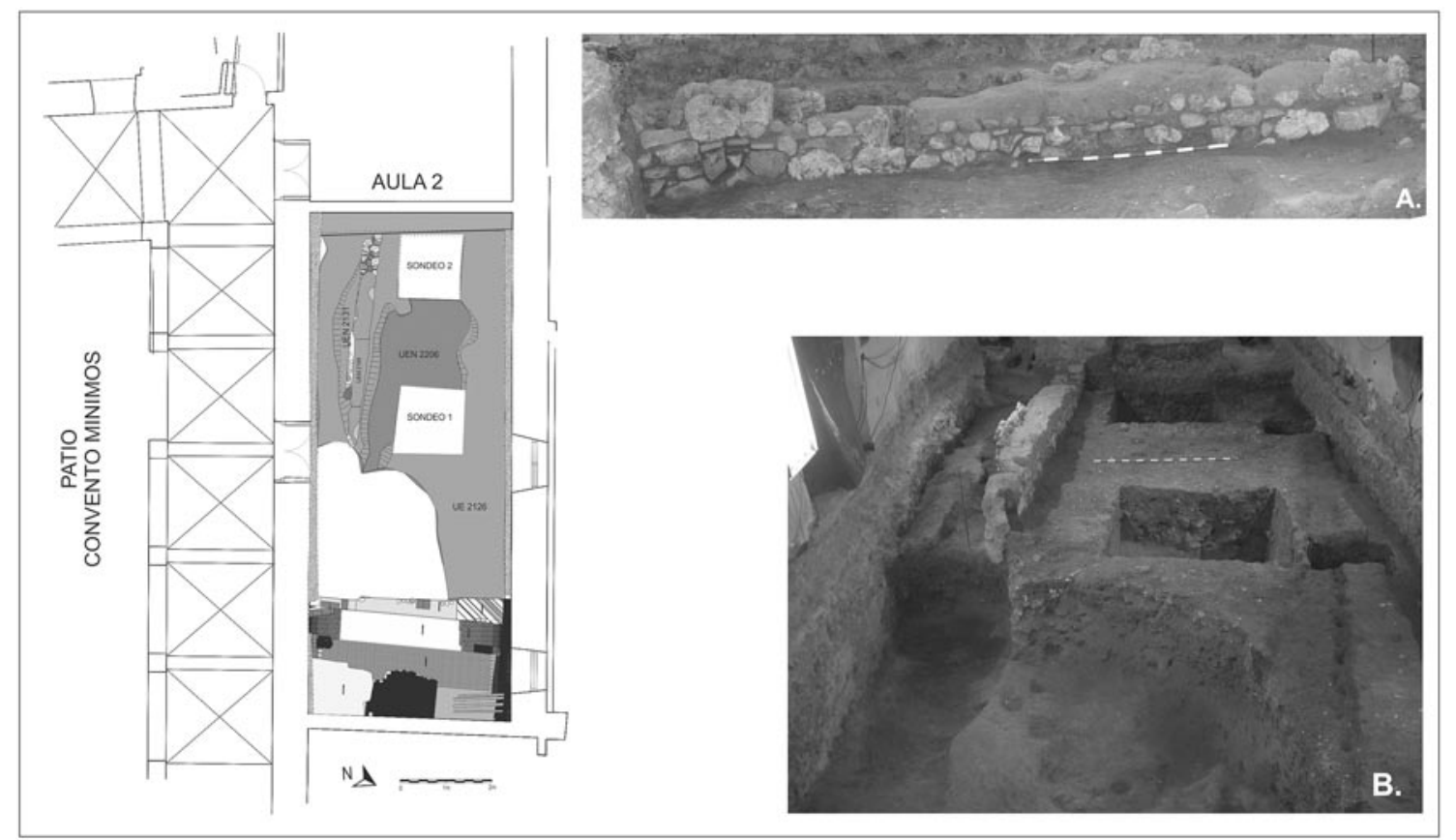

Fig. 29. Fase V: (viviendas finales s. XV- siglo XVI)) a. U.E.M. 2199. Fase V: (finales siglo XV) b. Fase IV-II: $\left(2^{a}\right.$ mitad siglo XV) U.E. 2126.

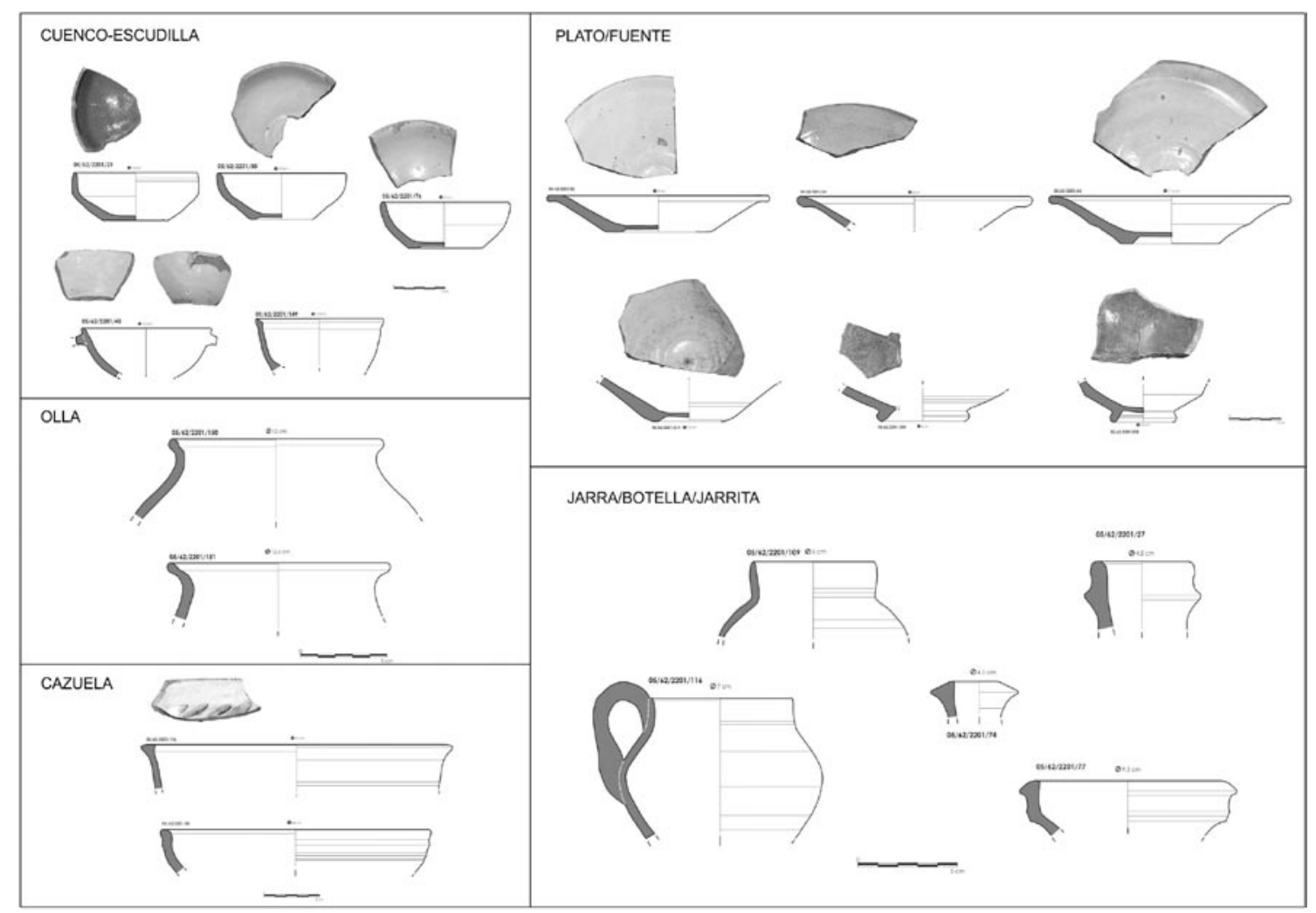

Fig. 30. Fase IV-III: (2ª mitad siglo XV). U.E. 220I. Series tipológicas. Cuenco-escudilla, Olla, Cazuela, Plato/Fuente, Jarra/BotellalJarrita. 

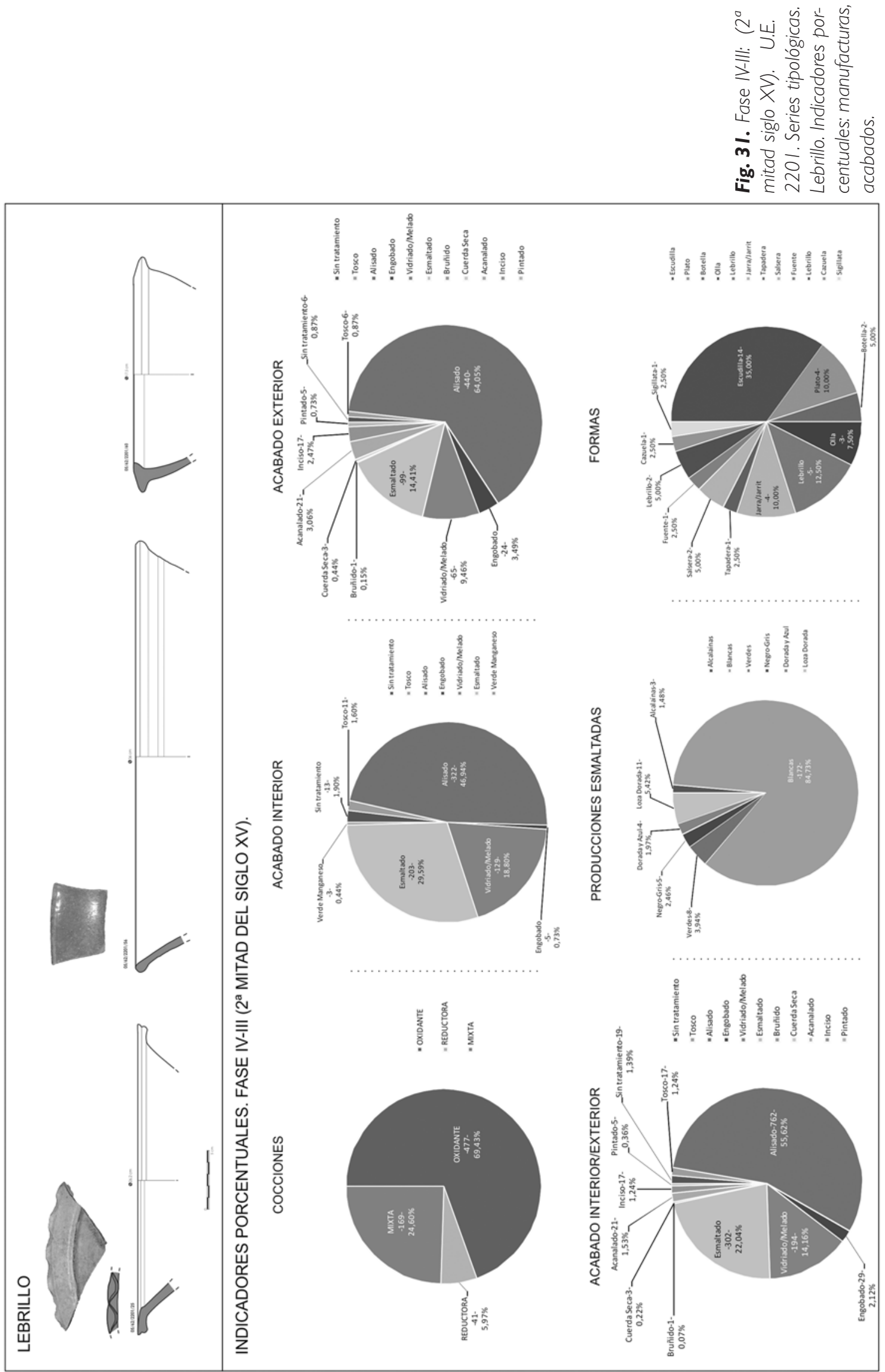


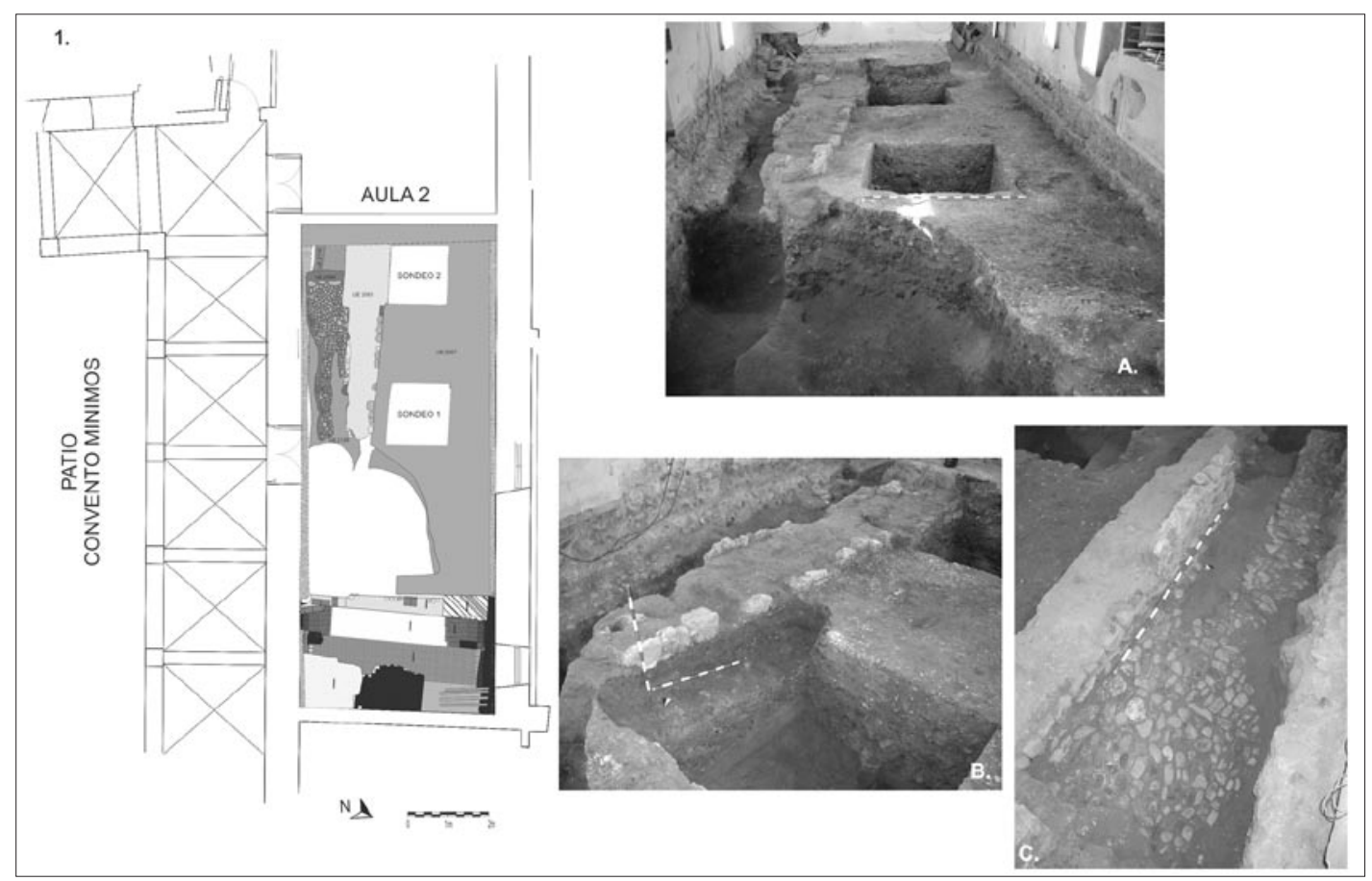

Fig. 32. Fase V: (viviendas finales s. XV- siglo XVI) A: U.E. 2067. B: U.E.M. 2083. C: U.E. 2084.

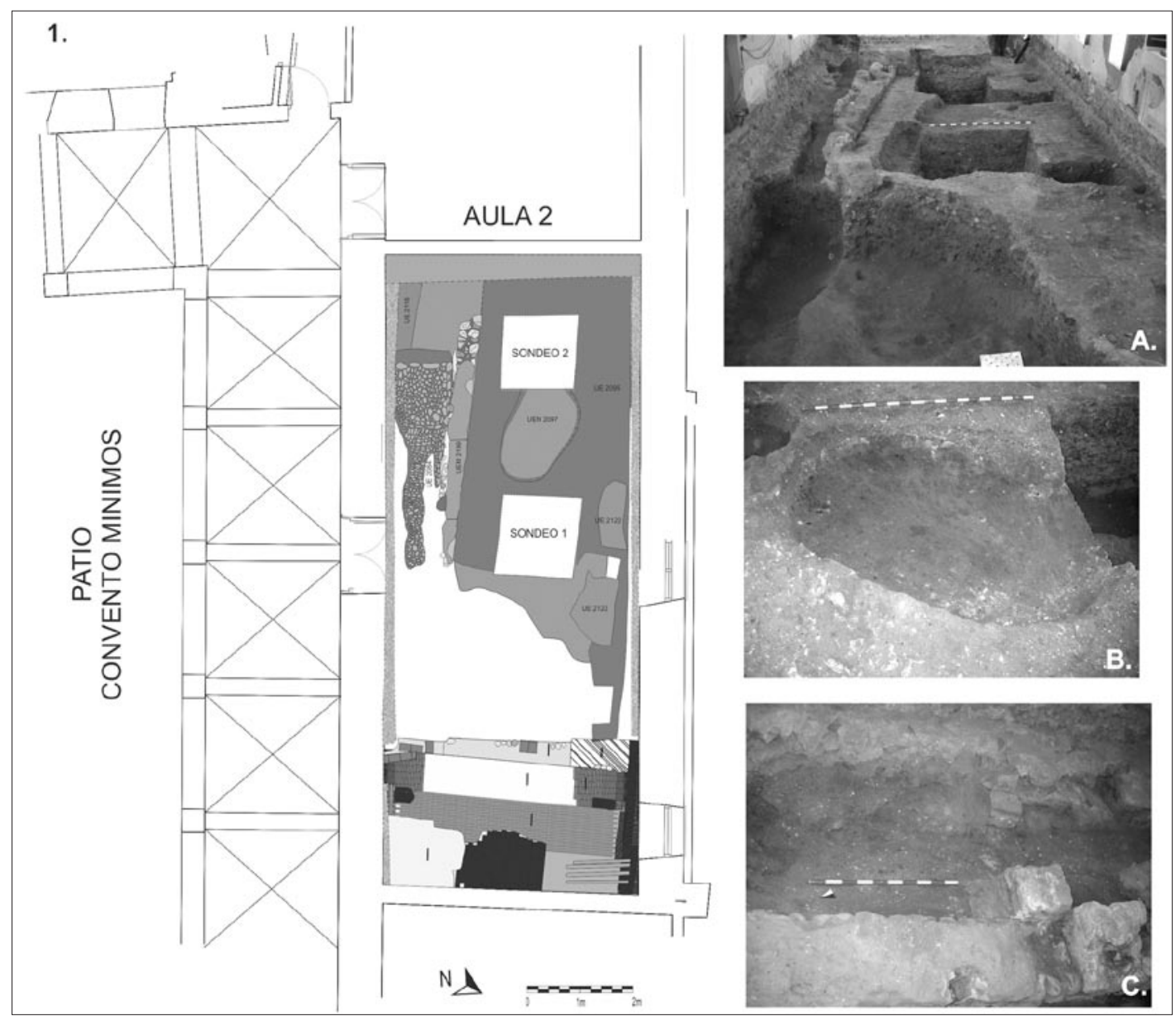

Fig. 33. Fase V: (viviendas finales s. XV- siglo XVI) A: U.E. 2095. B: U.E.N. 2097. C: U.E. 2106. 


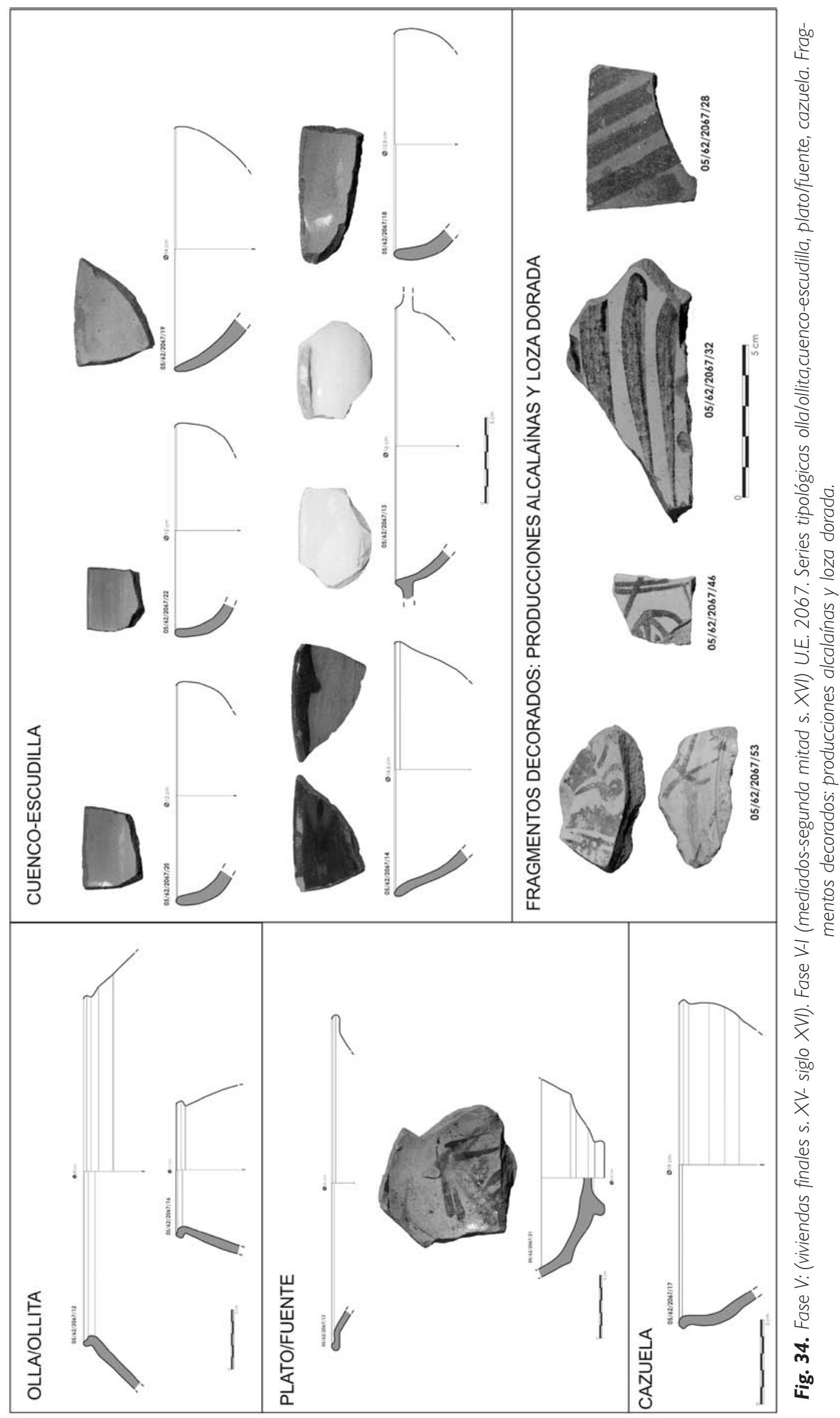




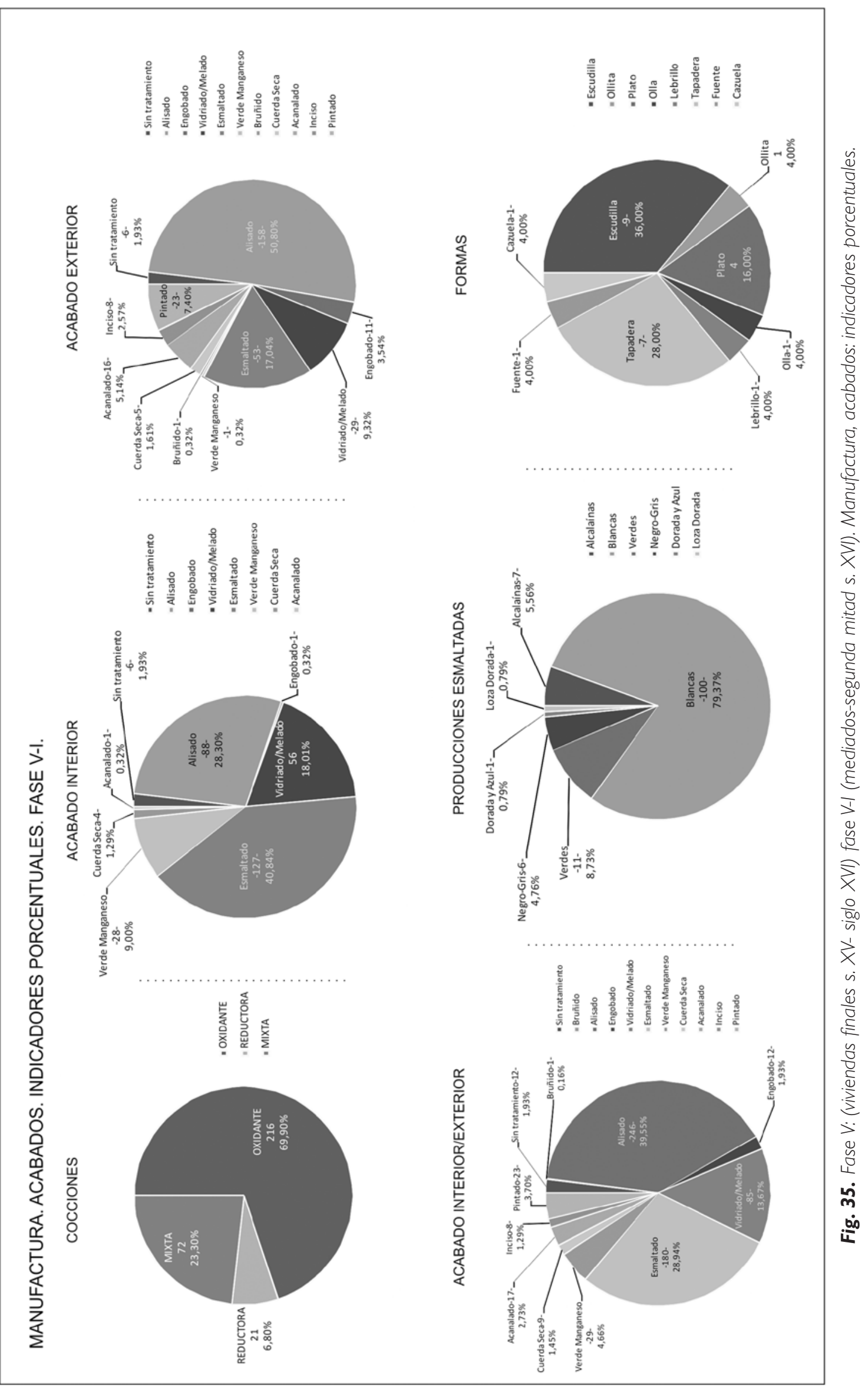




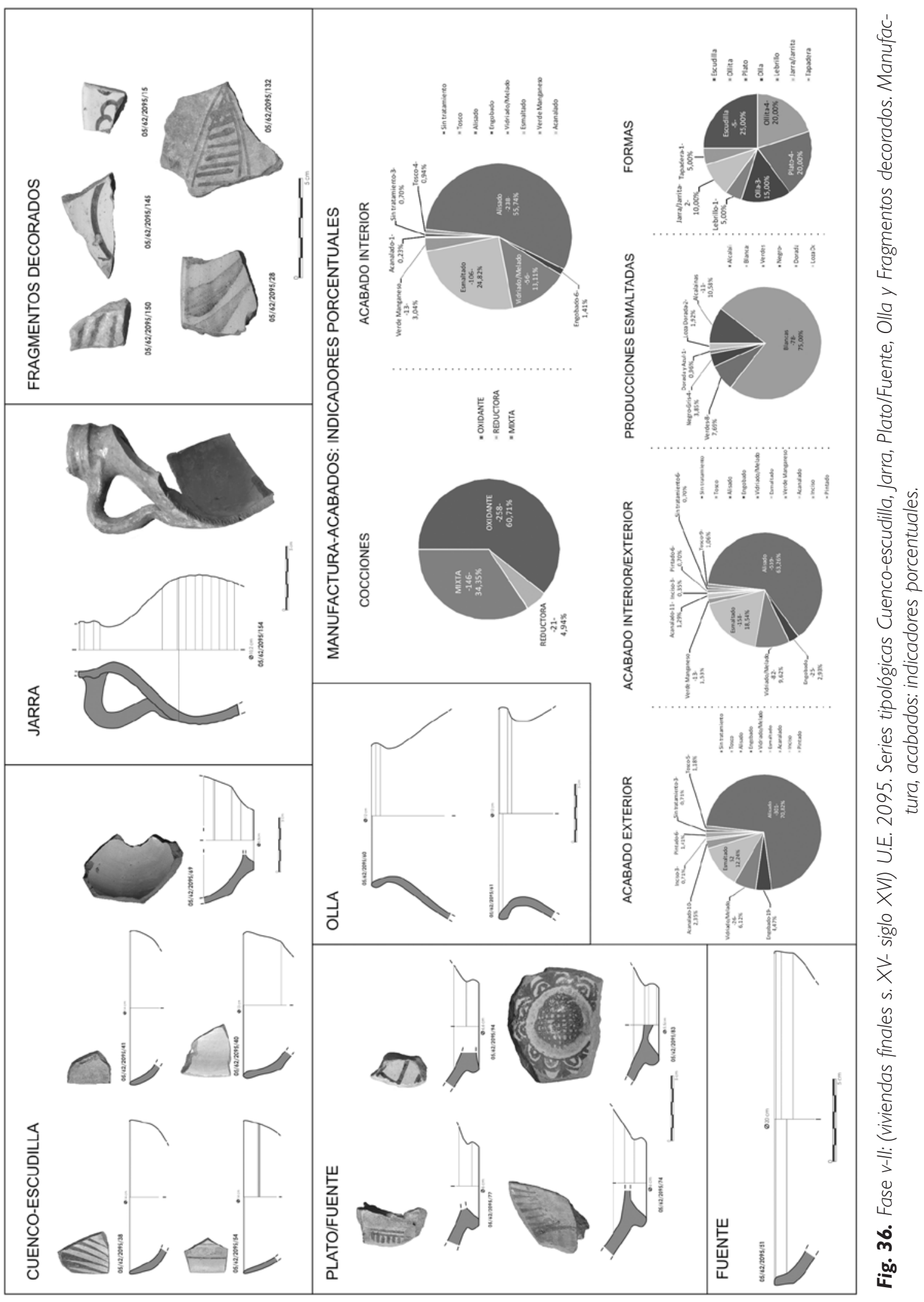



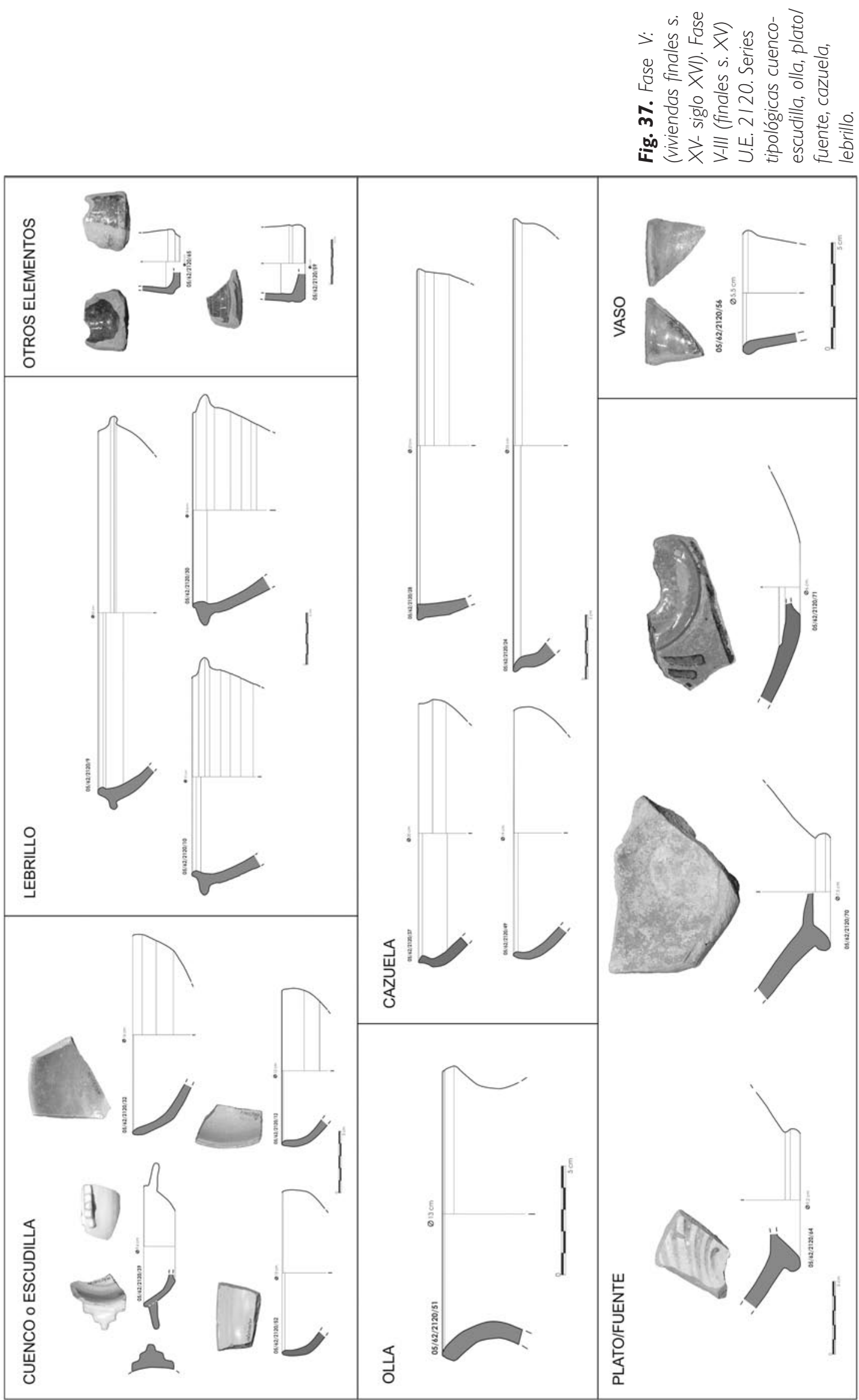


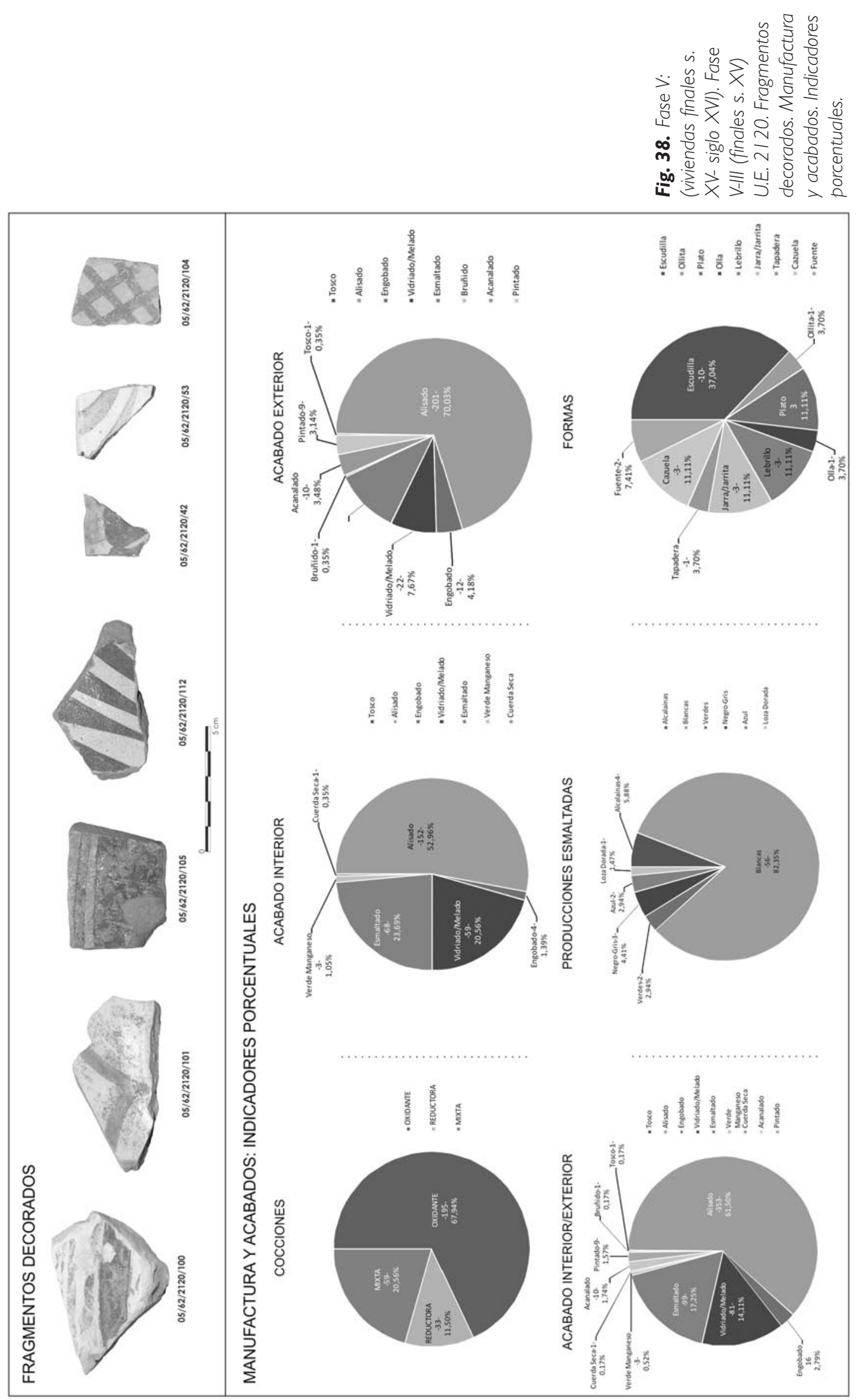




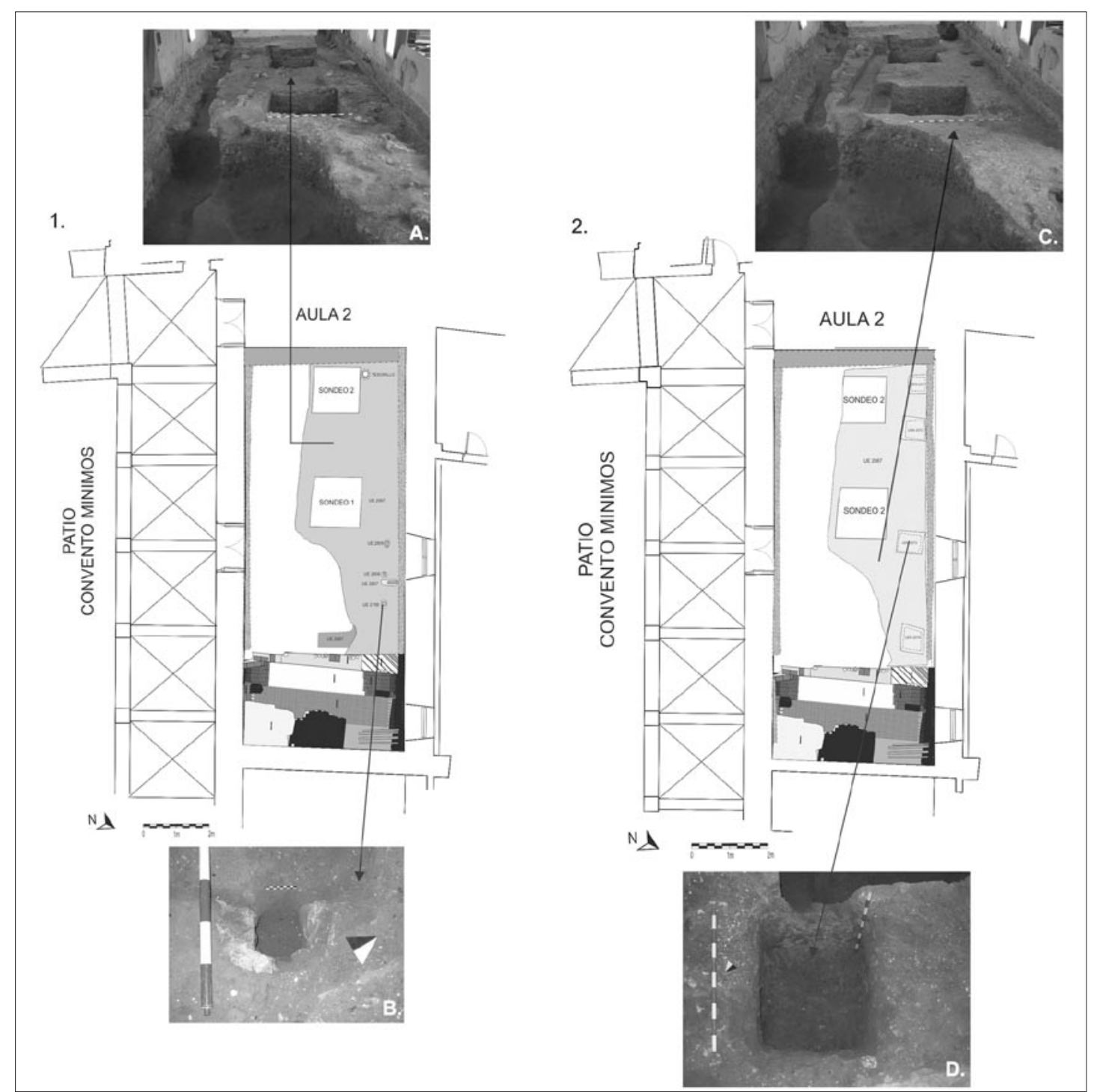

Fig. 39. I. Planta fase VI (construcción del complejo conventual 1580-1620). Subfase VI-II. U.E. 2063, Localización tesorillo y última fase de agujeros de apuntalamiento. A: U.E. 2063. B: Detalle fosa -agujero de apuntalamiento- U.E.N. 21 56. 2. Fase VI. Subfase III. Primera fase de fosas de apuntalamiento. C: U.E. 2067 -Estrato cortado por las fosas-. D: Detalle de fosa de apuntalamiento, U.E.N. 2073.

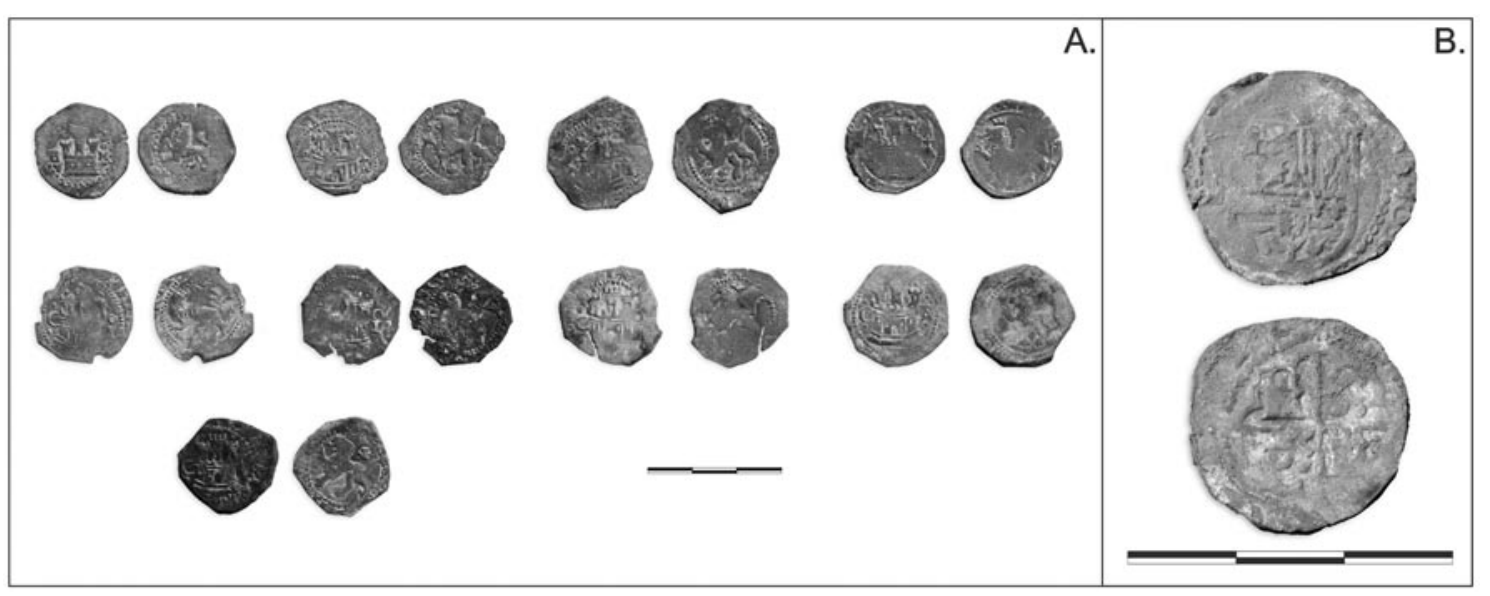

Fig. 40. Fase VI (construcción del complejo conventual) A: U.E. 2063. Nueve piezas de 2 maravedís (I 5561598). B: Un real de plata (I590), U.E. 1082. 


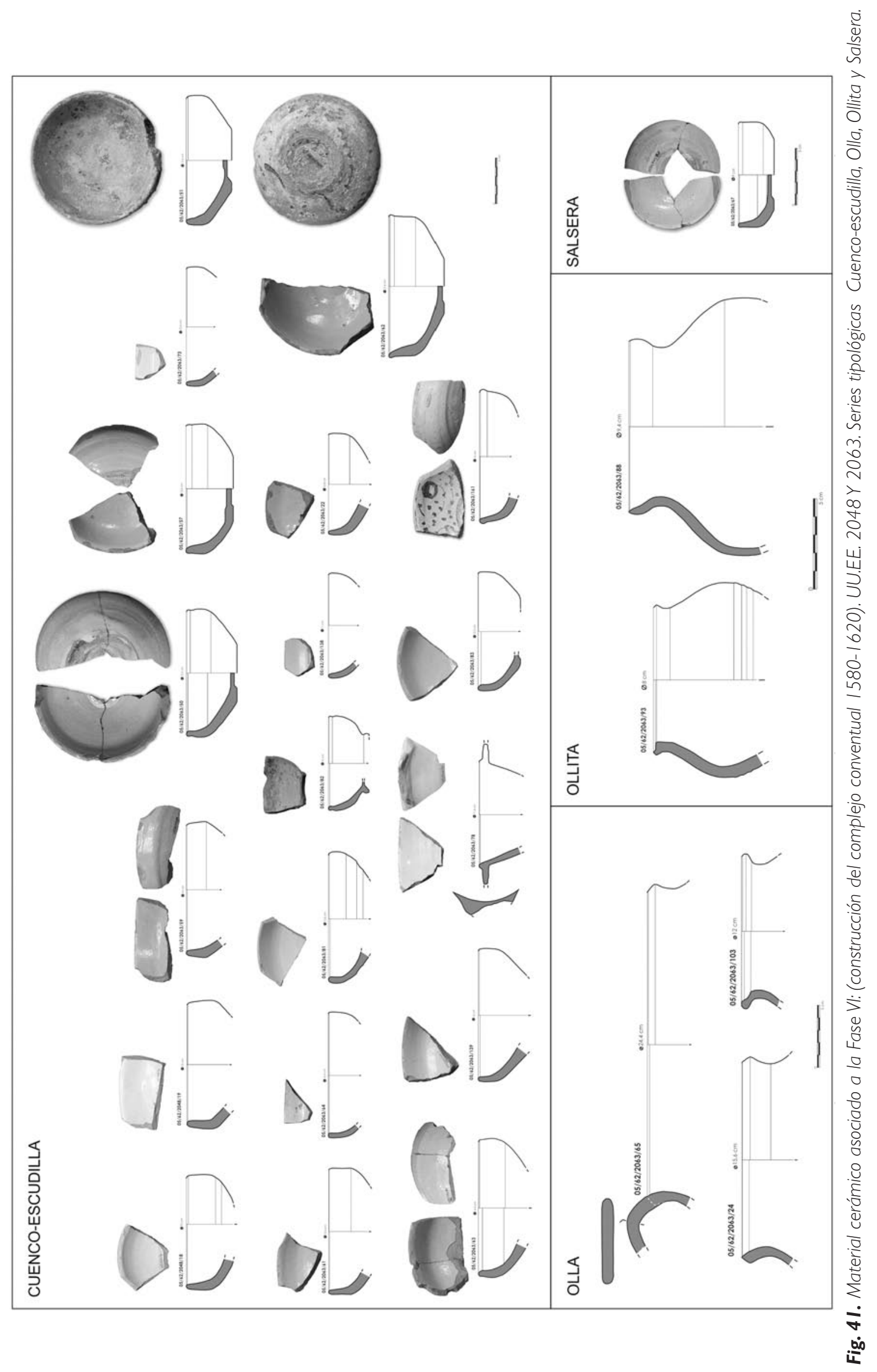




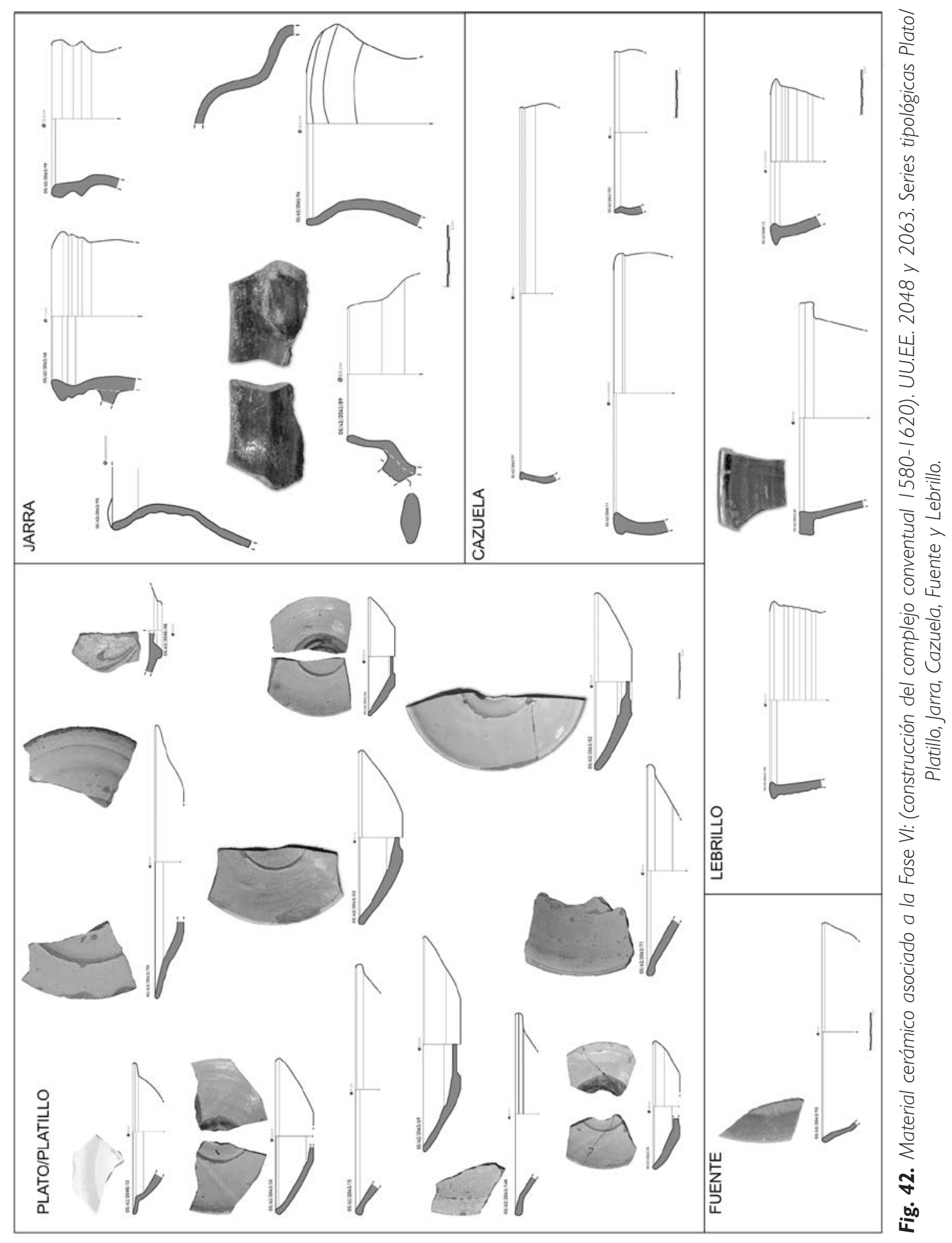




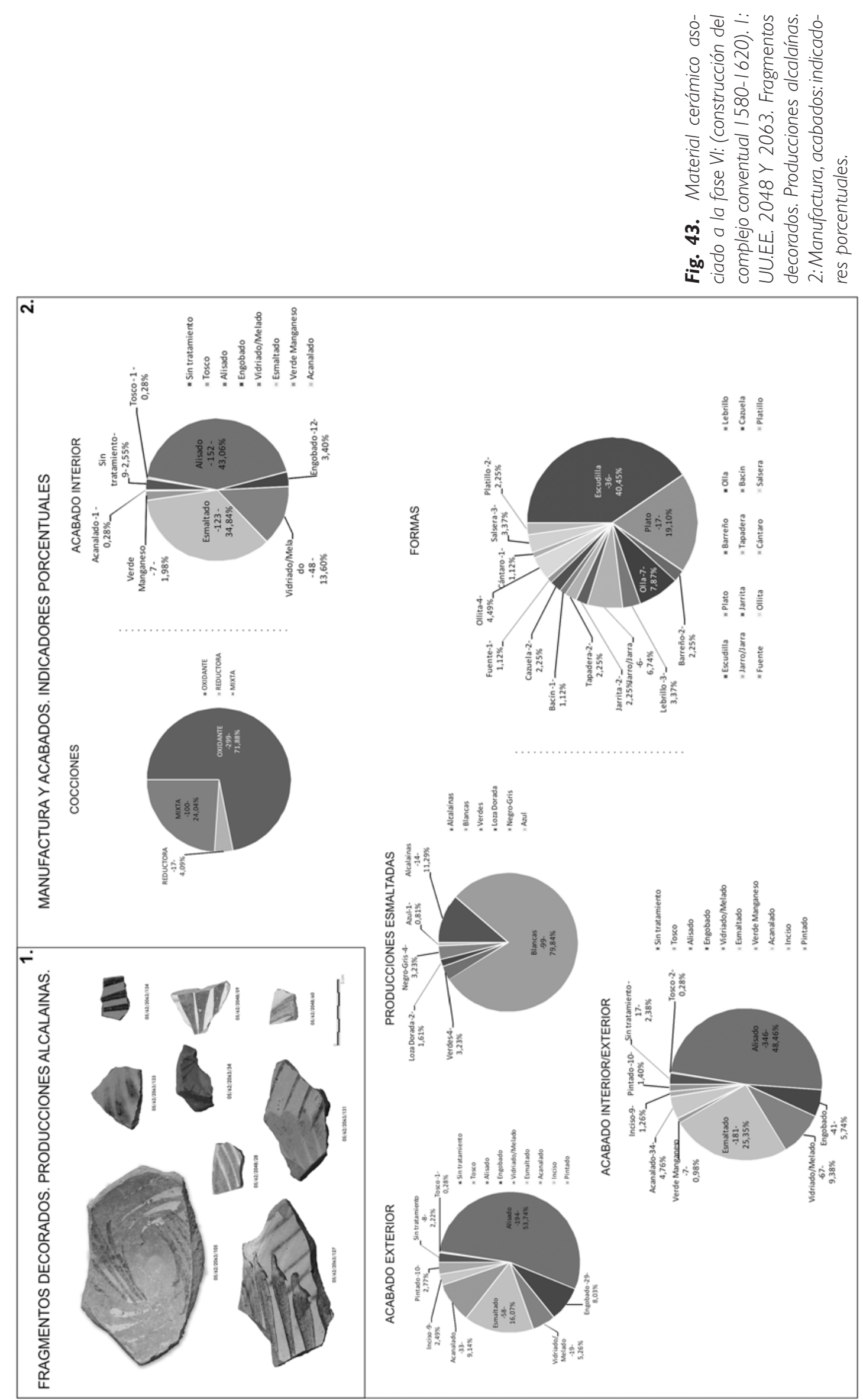




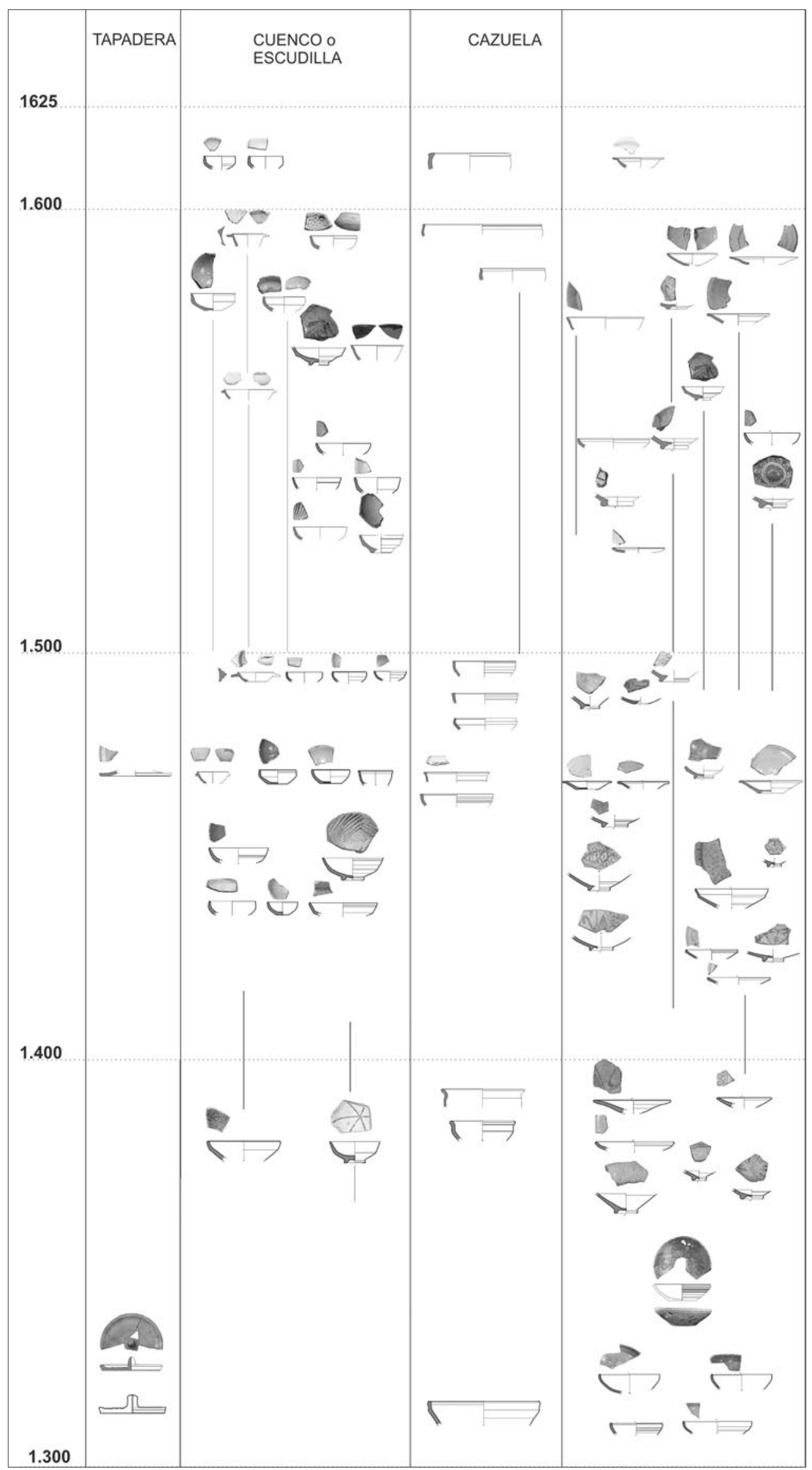

Fig. 44. Cuadro cronotipológico del Colegio de Mínimos de Santa Ana (Alcalá de Henares, Madrid). 


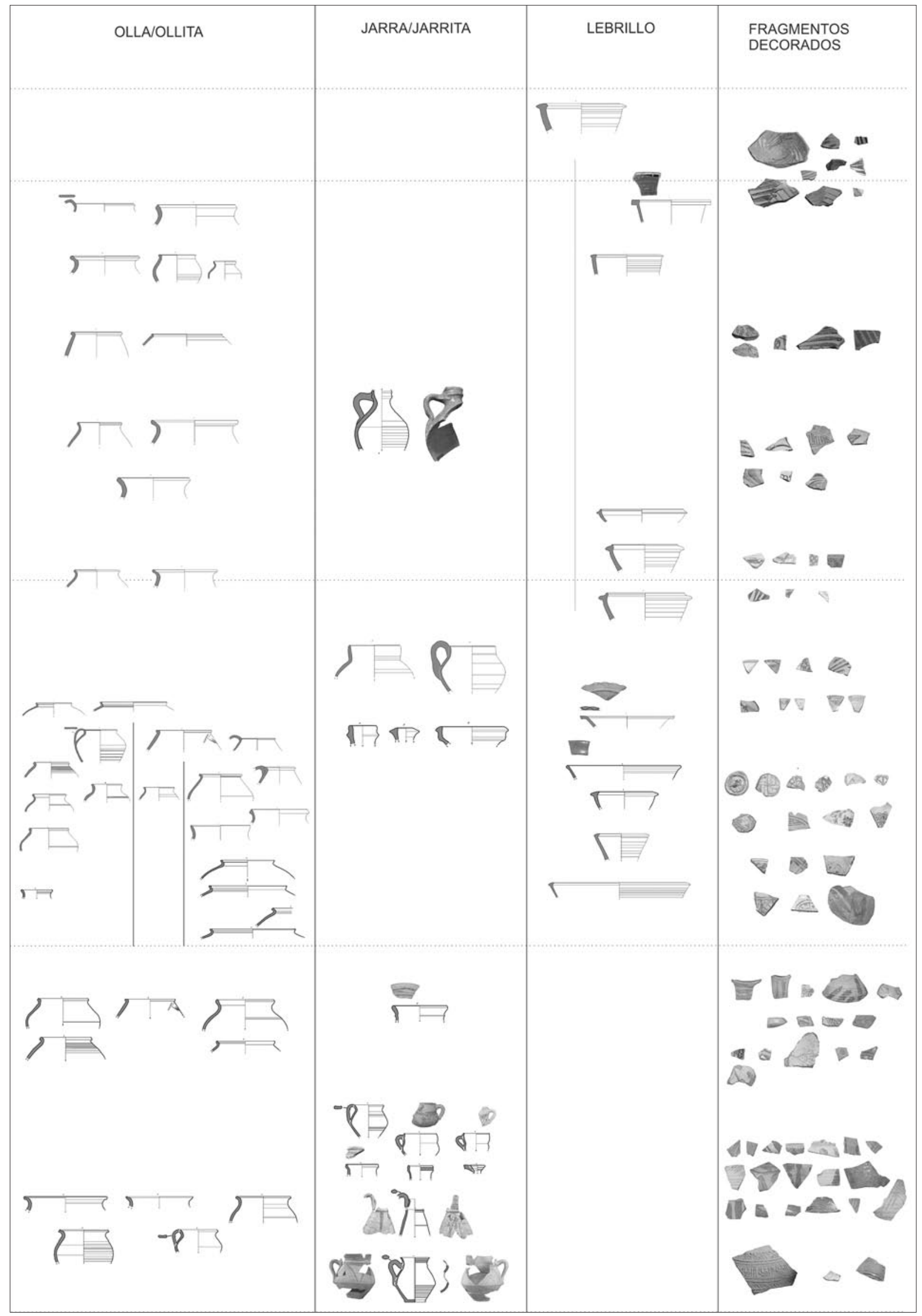

Fig. 44. (cont.) 